\title{
Guidelines
}

\section{Responsible, Safe, and Effective Use of Antithrombotics and Anticoagulants in Patients Undergoing Interventional Techniques: American Society of Interventional Pain Physicians (ASIPP) Guidelines}

Alan D. Kaye, MD, PhD¹, Laxmaiah Manchikanti, MD², Matthew B. Novitch³, Imran N. Mungrue ${ }^{4}$ Muhammad Anwar, MBBS ${ }^{5}$, Mark R. Jones, MD', Erik M. Helander, MBBS ${ }^{7}$, Elyse M. Cornett, $\mathrm{PhD}^{8}$, Matthew R. Eng, $\mathrm{MD}^{9}$, Jay S. Grider, DO, PhD ${ }^{10}$, Michael E. Harned, MD ${ }^{11}$, Ramsin M. Benyamin, MD ${ }^{12}$, John R. Swicegood, MD ${ }^{13}$, Thomas T. Simopoulos, MD ${ }^{14}$, Salahadin Abdi, MD, PhD ${ }^{15}$, Richard D. Urman, MD ${ }^{16}$, Timothy R. Deer, MD ${ }^{17}$, Cyrus Bakhit, MD ${ }^{18}$, Mahendra Sanapati, MD ${ }^{19}$, Sairam Atluri, MD ${ }^{20}$, Ramarao Pasupuleti, MD21, Amol Soin, MD22, Sudhir Diwan, MD²3, Ricardo Vallejo, MD, PhD ${ }^{24}$, Kenneth D. Candido, MD ${ }^{25}$, Nebojsa Nick Knezevic, MD, PhD²6, Douglas Beall, MD27, Sheri L. Albers, DO28, Richard Latchaw, MD ${ }^{29}$, Hari Prabhakar, MD ${ }^{30}$, and Joshua A. Hirsch, MD ${ }^{31}$

From: American Society of Interventional Pain Physicians

Author Affiliations and Disclosures on pp. S114-S115

Address Correspondence: Laxmaiah Manchikanti, MD 2831 Lone Oak Road Paducah, Kentucky 42003 E-mail:drlm@thepainmd.com

Manuscript received: $11-15-2018$ Revised manuscript received: 12-15-2018 Accepted for publication: 1-03-2019

Free full manuscript: www.painphysicianjournal.com
Background: Interventional pain management involves diagnosis and treatment of chronic pain. This specialty utilizes minimally invasive procedures to target therapeutics to the central nervous system and the spinal column. A subset of patients encountered in interventional pain are medicated using anticoagulant or antithrombotic drugs to mitigate thrombosis risk. Since these drugs target the clotting system, bleeding risk is a consideration accompanying interventional procedures. Importantly, discontinuation of anticoagulant or antithrombotic drugs exposes underlying thrombosis risk, which can lead to significant morbidity and mortality especially in those with coronary artery or cerebrovascular disease. This review summarizes the literature and provides guidelines based on best evidence for patients receiving anti-clotting therapy during interventional pain procedures.

Study Design: Best evidence synthesis.

Objective: To provide a current and concise appraisal of the literature regarding an assessment of the bleeding risk during interventional techniques for patients taking anticoagulant and/or antithrombotic medications.

Methods: A review of the available literature published on bleeding risk during interventional pain procedures, practice patterns and perioperative management of anticoagulant and antithrombotic therapy was conducted. Data sources included relevant literature identified through searches of EMBASE and PubMed from 1966 through August 2018 and manual searches of the bibliographies of known primary and review articles.

Results:

1. There is good evidence for risk stratification by categorizing multiple interventional techniques into low-risk, moderate-risk, and high-risk. Also, their risk should be upgraded based on other risk factors.

2. There is good evidence for the risk of thromboembolic events in patients who interrupt antithrombotic therapy.

3. There is good evidence supporting discontinuation of low dose aspirin for high risk and moderate risk procedures for at least 3 days, and there is moderate evidence that these may be continued for low risk or some intermediate risk procedures. 
4. There is good evidence that discontinuation of anticoagulant therapy with warfarin, heparin, dabigatran

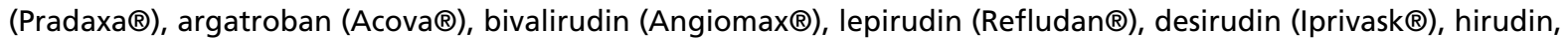

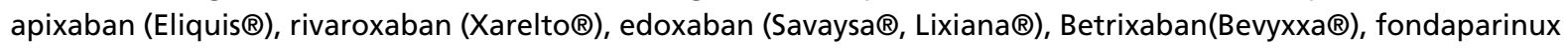
(Arixtra ${ }^{\circledR}$ ) prior to interventional techniques with individual consideration of pharmacokinetics and pharmacodynamics of the drugs and individual risk factors increases safety.

5. There is good evidence that diagnosis of epidural hematoma is based on severe pain at the site of the injection, rapid neurological deterioration, and MRI with surgical decompression with progressive neurological dysfunction to avoid neurological sequelae.

6. There is good evidence that if thromboembolic risk is high, low molecular weight heparin bridge therapy can be instituted during cessation of the anticoagulant, and the low molecular weight heparin can be discontinued 24 hours before the pain procedure.

7. There is fair evidence that the risk of thromboembolic events is higher than that of epidural hematoma formation with the interruption of antiplatelet therapy preceding interventional techniques, though both risks are significant.

8. There is fair evidence that multiple variables including anatomic pathology with spinal stenosis and ankylosing spondylitis; high risk procedures and moderate risk procedures combined with anatomic risk factors; bleeding observed during the procedure, and multiple attempts during the procedures increase the risk for bleeding complications and epidural hematoma.

9. There is fair evidence that discontinuation of phosphodiesterase inhibitors is optional (dipyridamole [Persantine], cilostazol [Pletal]. However, there is also fair evidence to discontinue Aggrenox [dipyridamole plus aspirin]) 3 days prior to undergoing interventional techniques of moderate and high risk.

10. There is fair evidence to make shared decision making between the patient and the treating physicians with the treating physician and to consider all the appropriate risks associated with continuation or discontinuation of antithrombotic or anticoagulant therapy.

11. There is fair evidence that if thromboembolic risk is high antithrombotic therapy may be resumed 12 hours after the interventional procedure is performed.

12. There is limited evidence that discontinuation of antiplatelet therapy (clopidogrel [Plavix®], ticlopidine [Ticlid $\circledast$ ], Ticagrelor [Brilinta $®$ ] and prasugrel [Effient $\left.{ }^{\circledR}\right]$ ) avoids complications of significant bleeding and epidural hematomas.

13. There is very limited evidence supporting the continuation or discontinuation of most NSAIDs, excluding aspirin, for 1 to 2 days and some 4 to 10 days, since these are utilized for pain management without cardiac or cerebral protective effect.

Limitations: The continued paucity of the literature with discordant recommendations.

Conclusion: Based on the survey of current literature, and published clinical guidelines, recommendations for patients presenting with ongoing antithrombotic therapy prior to interventional techniques are variable, and are based on comprehensive analysis of each patient and the risk-benefit analysis of intervention.

Key words: Perioperative bleeding, bleeding risk, practice patterns, anticoagulant therapy, antithrombotic therapy, interventional techniques, safety precautions, pain

Disclaimer: These guidelines are based on the best available evidence and do not constitute inflexible treatment recommendations. Due to the changing body of evidence, this document is not intended to be a "standard of care."

Pain Physician 2019: 22:S75-S128 


\subsection{InTRODUCTION}

$\mathrm{W}$ ith the increasing use of prescription medications to manage thrombosis risk and the ease of availability of over-thecounter and herbal products that mediate or modulate the coagulation cascade (1-21), and techniques to manage chronic pain, interventional pain physicians frequently encounter the challenge of potential risk of bleeding or thrombosis in perioperative management of these patients $(1,13,14,20,22-54)$. Modulation of anticoagulant and antithrombotic therapy during performance of interventional techniques is one of the major clinical decisions often made without precise evidence-based literature to support existing opinions $(1,13,14,20,31-54)$. Leading causes of morbidity and mortality worldwide include cardiovascular and cerebrovascular disease (4,5,55-58). In addition, one of the leading causes of disability and functional impairment across the globe is chronic persistent pain (29,30,59-66). Therefore, overlap between chronic persistent pain and cardiovascular disease has a synergistic impact on physical and psychological health, affecting performance of social responsibilities, including work and family life. Antithrombotic therapy has a clear evidence-based foundation with a favorable risk-benefit profile for prevention and management of cardiovascular disease, including limiting the present and future burden of cardiac or cerebrovascular infarcts $(4,5,15-19,55-58,67-81)$. Of note, a significant proportion of patients with established cerebrovascular, cardiovascular or peripheral vascular disease who are receiving antithrombotic therapy, are commonly in need of interventions including surgery and interventional pain management techniques, despite the debate regarding their safety, clinical and cost effectiveness, and indications with numerous regulations $(1,22-30,81$ 121).

Based on a survey of common practices by a majority of interventional pain physicians, discontinuation of antiplatelet therapy and anticoagulant therapy is common (31). The results of this survey showed discontinuation rate of warfarin therapy $100 \%$, clopidogrel $97 \%$, ticlopidine $96 \%$, Aggrastat or tirofiban $95 \%$, cilostazol $93 \%$, dipyridamole $85 \%$, aspirin $350 \mathrm{mg} 60 \%$, aspirin $81 \mathrm{mg} \mathrm{39 \%}$, and other nonsteroidal anti-inflammatory drugs (NSAIDs) 39\% prior to performing interventional pain management techniques. The majority of physicians accepted an international normalized ratio (INR) of 1.5 or less as a safe level. In another survey performed in 2012 by the American Society of Regional Anesthesia and Pain Medicine (ASRA), 55\% stopped aspirin before spinal cord stimulation trials and implants, and 32\% stopped before epidural steroid injections (40). The results of this study showed that only $36 \%$ knew that selective serotonin reuptake inhibitors (SSRIs) may lead to a bleeding disorder. Further, $17 \%$ utilized different protocols for cervical spine injections as compared with lumbar spine injections. This study (40) also showed that most physicians ( $88 \%$ ) expressed the need for pain physicians to communicate with other physicians.

Based on published guidelines, derived by clinical case reports and consensus, a large subset of clinicians report stopping antiplatelet therapy and consider this concept as a standard of care $(1,20,33,36-38,122-129)$. Although the overall incidence of bleeding complications and epidural hematoma in the non-obstetric epidural literature has been reduced, the incidence has been higher with procedures involving cervical and thoracic spine $(1,31-42,52-54,129)$. Of note, the clinical literature reports of incidences of epidural hematoma cases accompanying interventional techniques and neuraxial techniques are increasing rapidly $(1,20,31$ 42,130-149). While some reports indicate a decreasing incidence of bleeding complications related to neuraxial techniques (145), multiple studies have been performed assessing the prevalence and risks related to bleeding complications and epidural hematoma with neuraxial procedures, specifically interventional techniques $(1,20,31-42,50,51,138-149)$.

Significant risks of withdrawing antiplatelet therapy include cardiovascular, cerebrovascular, and peripheral vascular thrombosis. In addition, the risks are higher in chronic pain patients as chronic psychosocial stress causes a hypercoagulable state, as reflected by increased procoagulant molecular fibrinogen (or coagulation factor 7), reduced fibrinolytic capacity and increased platelet activity $(40,150-152)$. Stress has been shown to affect coagulation activity via an influence on the regulation of genes coding for coagulation and fibrinolysis molecules (152) with increase in hormonal levels (153-155) and an underlying surge of catecholamine and cortisol induced hypercoagulability (155). A prior systematic review and meta-analysis explored the hazards of discontinuing or altering aspirin regimens among patients at risk for coronary artery disease (69). Importantly, in patients at moderate to high risk for coronary artery disease, withdrawal or noncompliance 
with aspirin therapy was associated with 3-fold higher risk of major adverse cardiac events and the risk was magnified in patients with coronary stents. The findings support the recommendation that aspirin discontinuation in this patient population should be advocated only under circumstances where the risk of adverse outcomes caused by bleeding risk clearly outweighs that of catastrophic atherothrombotic events. These findings have been confirmed in later studies $(70-78,150)$. Conversely, recently published large-scale evidence (15-19) shows lack of benefit of aspirin for primary prevention of cardiovascular events, but aspirin therapy is associated with increased bleeding episodes. Thus, current evidence suggests that the risks of coronary events related to patients abstaining from their antiplatelet medications during the perioperative period are more serious when compared to the risks of continuing antiplatelet therapy through the perioperative period.

Multiple publications $(1,32,33,42,46,138,140)$ have also supported the concept of continuing antiplatelet/ anticoagulant agents in patients undergoing various interventional pain procedures in light of identical complication rates as compared to the patients who stop taking these for a particular recommended period. It should be noted that there are only a few clinical reports of an epidural hematoma available in patients undergoing interventional therapies for chronic pain, which included patients both continuing and discontinuing antithrombotic therapy.

The American Society of Interventional Pain Physicians (ASIPP) has developed multiple guidelines, both for interventional techniques and opioids $(29,66,82)$. Consequently, the present investigation has been undertaken to develop responsible, safe, and effective guidelines for patients on antithrombotic and anticoagulant therapy undergoing interventional techniques. These guidelines offer an overview of the current literature applicable to antithrombotic and anticoagulant therapy and the related complications, with incorporation of various aspects of the current national and international recommendations.

\subsection{Methods}

\subsection{Rationale}

Interventional pain management physicians provide a significant number of multidisciplinary strategies including physical therapy, behavioral treatments, pharmacological, and interventional management to patients with chronic pain. The National Uniform
Claims Committee (NUCC) defined interventional pain management as the discipline of medicine devoted to the diagnosis and treatment of pain-related disorders, principally with the application of interventional techniques in managing subacute, chronic, persistent, and intractable pain, independently or in conjunction with other modalities of treatment (156). In addition, the Medicare Payment Advisory Commission (MedPAC) defined interventional pain management techniques as minimally invasive procedures including, percutaneous precision needle placement with placement of drugs in targeted areas or ablation of targeted nerves; and some surgical techniques such as laser or endoscopic discectomy, intrathecal infusion pumps and spinal cord stimulators, for the diagnosis and management of chronic, persistent or intractable pain (157).

Chronic spinal pain is a complex and multifactorial phenomenon. Interventional pain physicians are familiar with various pathophysiologic, anatomic, and technical aspects of multiple interventional techniques applied in managing chronic pain.

\subsection{Objectives}

The objectives of these guidelines are to synthesize the available evidence on the safety, as well as adverse effects of antithrombotic and anticoagulant therapy for patients undergoing interventional techniques in the treatment of chronic spinal pain, and provide a rational and systematic approach to their application.

\subsection{Adherence to Trustworthy Standards}

In preparation of these guidelines to develop responsible, safe, and effective guidelines for patients on antithrombotic and anticoagulant therapy undergoing interventional techniques, the Institute of Medicine (IOM) standards and the National Guideline Clearinghouse Extent Adherence to Trustworthy Standards (NEATS) instruments were followed (158-160). The NEATS instrument was developed and tested as a tool to be used by the trained staff at the Agency for Healthcare Research and Quality (AHRQ) National Guideline Clearinghouse to provide assessment focused on adherence.

\subsubsection{Disclosure of Guideline Funding Source}

Responsible, safe, and effective guidelines for patients on antithrombotic and anticoagulant therapy undergoing interventional techniques were commissioned, prepared, edited, and endorsed by ASIPP without external funding sought or obtained. 
Table 1. Qualitative modified approach to grading of evidence.

\begin{tabular}{|l|l|l||}
\hline Level I & Strong & $\begin{array}{l}\text { Evidence obtained from multiple relevant high quality randomized controlled trials for } \\
\text { effectiveness }\end{array}$ \\
\hline Level II & Moderate & $\begin{array}{l}\text { Evidence obtained from at least one relevant high quality randomized controlled trial or } \\
\text { multiple relevant moderate or low quality randomized controlled trials }\end{array}$ \\
\hline Level III & Fair & $\begin{array}{l}\text { Evidence obtained from at least one relevant high quality nonrandomized trial or observational } \\
\text { study with multiple moderate or low quality observational studies }\end{array}$ \\
\hline Level IV & Limited & Evidence obtained from multiple moderate or low quality relevant observational studies \\
\hline Level V & Consensus based & $\begin{array}{l}\text { Opinion or consensus of large group of clinicians and/or scientists for effectiveness as well as to } \\
\text { assess preventive measures, adverse consequences, effectiveness of other measures. }\end{array}$ \\
\hline
\end{tabular}

Modified from: Manchikanti et al. A modified approach to grading of evidence. Pain Physician 2014; 17:E319-E325 (161).

\subsubsection{Disclosure and Management of Financial Conflicts of Interests}

Potential conflicts of interest for all panel members within the last 5 years were evaluated prior to finalizing these guidelines. However, the panel members with potential conflicts were instructed by the panel and recused from related discussion or preparation of the guidelines and these members agreed not to discuss any aspect of the guideline with the industry before data publication. Further, conflicts of interests were included based on interest confluence extending beyond financial relationships including personal experience, practice patterns, academic interests and promotions.

\subsubsection{Composition of the Guideline Development Group}

A panel of experts, convened by ASIPP, reviewed the evidence and formulated recommendations for interventional techniques in patients receiving antiplatelet and anticoagulant therapy. The panel was instructed to assess the evidence pertaining to all important aspects of therapy and related complications.

The panel provided a broad representation of academic and non-academic clinical practitioners with interest in interventional techniques in patients receiving antiplatelet and anticoagulant therapy.

The panel composition was multidisciplinary including methodologists (e.g., epidemiologists, statisticians, and health services researchers) with experience in research and the conduct of systematic reviews. These members were voting members of the guideline development groups.

\subsection{Evidence Review}

Responsible, safe, and effective guidelines for patients on antithrombotic and anticoagulant therapy undergoing interventional techniques were developed utilizing evidence review, incorporating guidelines by other organizations and agencies, if available, and developing consensus among the panel members.

The current guidelines offer recommendations based on scientific evidence and informed expert opinion.

\subsubsection{Grading or Rating the Quality or Strength of Evidence}

This grading of evidence is based on randomized controlled trials (RCTs), observational studies, and other clinical reports based on availability. In addition, systematic reviews, meta-analyses, and evidence developed by other guidance are also given high importance with critical analysis. The recommendations have been developed using principles of best evidence synthesis developed by the Cochrane Review, incorporating multiple guidelines modified by ASIPP as shown in Table 1 (161).

This methodology specifies a level of scientific evidence and offers a transparent approach to grading quality of evidence and strength of recommendations. AHRQ also has recommended a similar strength of recommendation as shown in Table $2(159,160)$.

\subsubsection{Assessment and Recommendations of Benefits and Harms}

These guidelines intend to clearly describe the potential benefits and harms and explicitly link the information to specific recommendations.

\subsubsection{Evidence Summary of Recommendations}

Guideline supporting documents summarize the relevant supporting evidence and explicitly link this information to recommendations.

\subsubsection{Rating or Grading the Strength of Recommendations}

IOM standards demand that for each recommenda- 
Table 2. Guide for strength of recommendations.

\begin{tabular}{||l|l||}
\hline \hline Rating for Strength of Recommendation \\
\hline Strong & $\begin{array}{l}\text { There is high confidence that the recommendation reflects best practice. This is based on: a) strong evidence for a true } \\
\text { net effect (e.g., benefits exceed harms); b) consistent results, with no or minor exceptions; c) minor or no concerns } \\
\text { about study quality; and/or d) the extent the panelists' agreement. Other compelling considerations (discussed in the } \\
\text { guideline's literature review and analyses) may also warrant a strong recommendation. }\end{array}$ \\
\hline Moderate & $\begin{array}{l}\text { There is moderate confidence that the recommendation reflects best practice. This is based on: a) good evidence for a } \\
\text { true net effect (e.g. benefits exceed harms); b) consistent results, with minor and/or few exceptions; c) minor and/or few } \\
\text { concerns about study quality; and/or d) the extent of panelists' agreement. Other compelling considerations (discussed } \\
\text { in the guideline's literature review and analyses) may also warrant a moderate recommendation. }\end{array}$ \\
\hline Weak & $\begin{array}{l}\text { There is some confidence that the recommendation offers the best current guidance for practice. This is based on: a) } \\
\text { limited evidence for a true net effect (e.g., benefits exceed harms); b) consistent results, but with important exceptions; } \\
\text { c) concerns about study quality; and/or d) the extent of panelists' agreement. Other considerations (discussed in the } \\
\text { guideline's literature review and analyses) may also warrant a weak recommendation. }\end{array}$ \\
\hline
\end{tabular}

Source: National Guideline Clearinghouse Extent Adherence to Trustworthy Standards (NEATS) instrument (159).

tion, a rating of the strength of the recommendation related to benefits and harms, available evidence, and the confidence in the underlying evidence should be provided (158).

\subsubsection{Specificity of Recommendations}

Guideline recommendations in this manuscript may not be very specific and occasionally may be ambiguous, on what actions should or should not be taken in various situations of antithrombotic and anticoagulant therapy during performance of interventional techniques due to the lack of extensive literature and discordant opinions.

\subsection{Evidence Synthesis and Analysis}

This comprehensive review was performed with appropriate literature review and assessment. Due to the complexity of the subject and lack of systematic assessment of bleeding complications and epidural hematomas in the literature, a systematic review and meta-analysis of RCTs and/or observational studies may not be feasible $(158,162-164)$. Consequently, these guidelines focus on the available literature in reference to epidemiologic studies, observational reports, and case reports. Further, appropriate methods of data extraction and methodologic quality assessment will be applied.

\subsubsection{Data Sources}

The literature search was strategized based on multiple available sources including PubMed, the Cochrane library, Google searches, the U.S. Food and Drug Administration (FDA), the Centers for Disease Control and Prevention (CDC), and controlled clinical trials. The search was conducted over a time frame spanning from 1966 to August 2018.

\subsubsection{Search Strategy}

The search strategy focused on antithrombotics, anticoagulants, antiplatelet agents, thrombotic events, cardiovascular events, cerebrovascular events, interventional techniques, bleeding complications, and epidural hematoma following interventional techniques.

\subsubsection{Study Selection}

The review focused on all types of reports and includes case reports and reviews.

- Abstracts were screened in an unblinded standardized manner by 2 review authors for all identified studies.

- Full text for all articles with relevance to the topic was retrieved for comprehensive review.

\subsubsection{Data Extraction and Methodological Quality Assessment}

Data extraction and methodologic quality assessment was performed by at least two of the review authors independently, in an unblinded standardized manner. The quality assessment of each individual article used in this analysis was performed by utilizing the Cochrane review criteria (Appendix Table 1) (165), Interventional Pain Management techniques Quality Appraisal of Reliability and Risk of Bias Assessment (IPM-QRB) criteria (Appendix Table 2) (166) for RCTs, and Interventional Pain Management Techniques - Quality Appraisal of Reliability and Risk of Bias Assessment for Nonrandomized Studies (IPM-QRBNR) (Appendix Table 3) (167). Utilizing the Cochrane review criteria (165) or IPM-QRB criteria (166), or IPM-QRBNR (167), studies meeting the inclusion criteria with a score of at least 9 to 13 for the Cochrane review criteria or 32 to 48 for the IPM-QRB and IPMQRBNR criteria were considered high quality; while 5 to 
8 or 16 to 31 were considered moderate quality; whereas those with scores of less than 5 or 16 were considered low quality. Due to the scarcity of the literature, all studies were included in data synthesis or analysis.

All systematic reviews, non-systematic reviews, all types of studies, and case reports were reviewed by 2 authors. Any disagreements between the reviewers were resolved by a third author and consensus. If there were any conflicts of interest with a manuscript (i.e., authorship) the review authors were recused from assessment and analysis.

\subsubsection{Analysis of Evidence}

The analysis of the evidence was performed based on best-evidence synthesis and was modified and collated using multiple available criteria, including the Cochrane Review criteria and the United States Preventive Task Force (USPSTF) criteria as illustrated in Table 1 (161). The analysis was conducted using 5 levels of evidence ranging from strong to opinion- or consensus-based. The results of best evidence as per grading were utilized. At least 2 of the review authors independently, in an unblinded, standardized manner, analyzed the evidence. Any disagreements between reviewers were resolved by a third author and consensus was attained. If there were any conflicts of interest (e.g., authorship), the reviewers of interest were recused from assessment and analysis.

\subsubsection{Meta-analysis}

The meta-analysis was planned to be performed using the Comprehensive Meta-analysis version 3.0 (Biostat Inc., Englewood, NJ). Heterogeneity will be interpreted through $\mathrm{I}^{2}$ statistic.

Random-effects model (single-arm) meta-analysis was planned to assess net changes in the same outcome variable (168-170). Heterogeneity among the effect sizes of individual studies will be assessed using the $\mathrm{I}^{2}$ index and Q statistic. Heterogeneity analyzed with the $I^{2}$ statistic was defined as low (25\%-50\%), moderate $(50 \%-75 \%)$, or high $(>75 \%)$.

All analyses were based on if antithrombotics or anticoagulants were utilized or stopped. Meta-analysis was performed only when at least 3 studies were available and included an appropriate sample size of at least 10 for nonrandomized studies.

\subsection{External Review}

Guidelines have been subjected to external peer review as per the policies of the publishing journal, Pain Physician.

\subsection{Updating Guidelines}

The responsible, safe, and effective guidelines for patients on antithrombotic and anticoagulant therapy undergoing interventional techniques will be updated in a window of 5 years, based on significant changes in the evidence, public policy, or adverse events before January 2024

\subsection{Results}

Our search strategy utilizing the Preferred Reporting Items for Systematic Reviews and Meta-Analyses (PRISMA) flow diagram as shown in Fig. 1, illustrated published literature evaluating interventional techniques performed with or without antithrombotic and anticoagulant therapy. We identified multiple systematic reviews and guidelines $(1,20,28,36,37,39,40,82,171$ 174 ) and multiple individual manuscripts which met the criteria for inclusion (175-212). Due to very few studies with persistent high variability, conventional metaanalysis or single-arm meta-analysis was feasible.

\subsection{Reviews and Guidelines}

Among the 12 manuscripts describing guidelines and reviews, 2 manuscripts were related to ASIPP guidelines $(1,82)$. The present guidelines are based on these guidelines published in 2013. Other guidelines of high importance are of the ones published by the ASRA (40). These guidelines have provided extensive descriptions with comprehensive review of the literature; however, these have been considered as more aggressive about stopping the antithrombotics than other available literature (36). Nevertheless, these are commonly utilized guidelines in the United States. Multiple other manuscripts include the guidelines from across the globe and reviews. A review by Oprea et al (20) described risk stratification, perioperative and periprocedural management of the patient receiving anticoagulant therapy.

In addition, there were also guidelines related to the Neurostimulation Appropriateness Consensus Committee with recommendations on bleeding and coagulation management in neurostimulation devices (39). The guidelines from ASRA (40) and guidelines for neuromodulation procedures (39) stratified procedures into various risk categories. The guidelines by ASRA were revised which was prompted by reports of percutaneous lead placement with development of epidural hematoma in patients on aspirin. Prior to these recommendations, low dose aspirin was considered as safe and was not stopped during interventional techniques including spinal cord stimulation. 


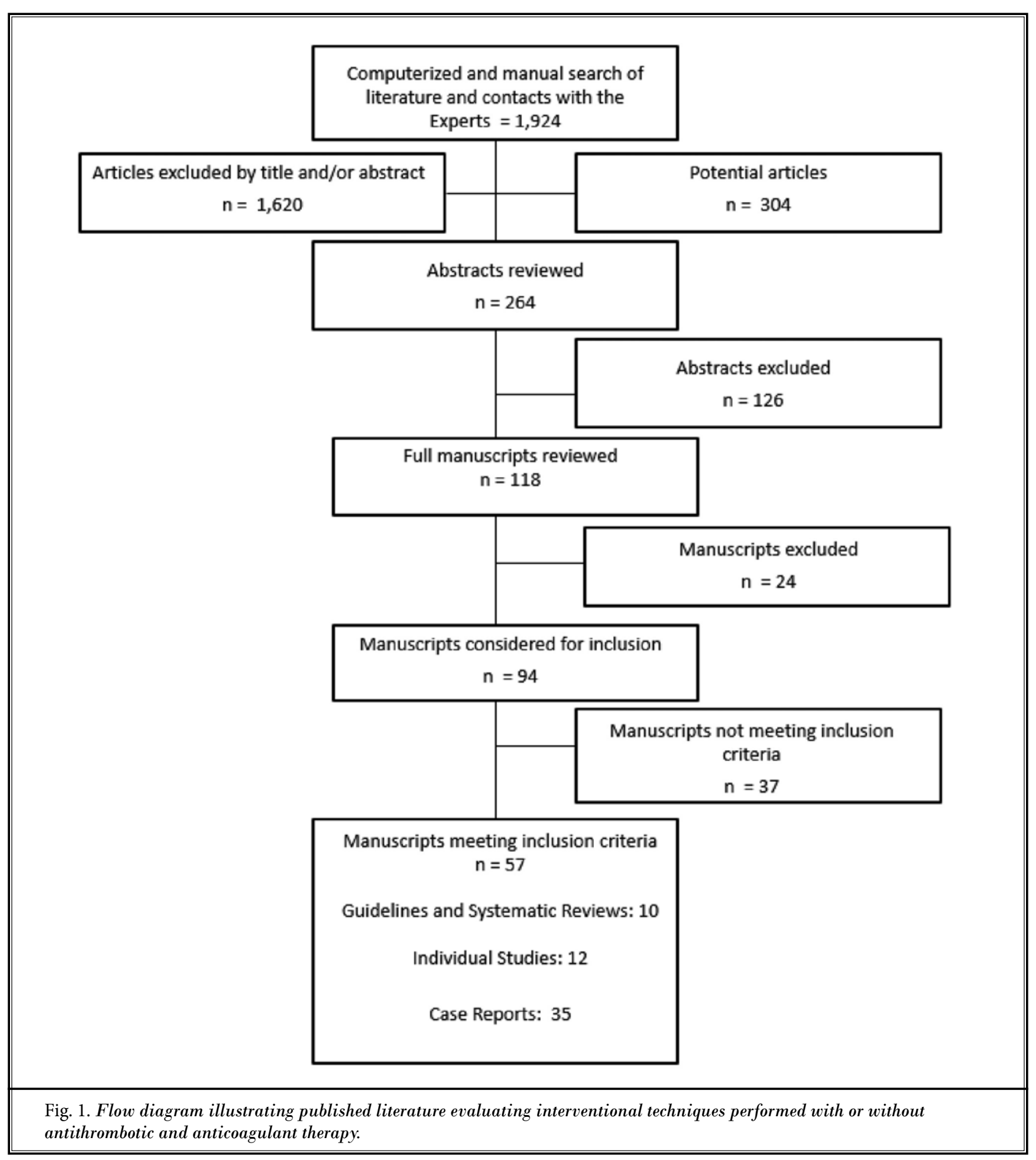

Breivik et al (36) provided a comprehensive review of reducing the risk of spinal hematoma from spinal and epidural pain procedures. They provided recommendations for interventional techniques with updated guidance.
In addition, in a quasi-systematic review assessing the risks and benefits of ceasing or continuing anticoagulant medication for image-guided procedures for spine pain (33), the authors evaluated 14 manuscripts which provided applicable evidence. The results showed 
procedures involving interlaminar access carried a nonzero risk of hemorrhagic complications, regardless of whether anticoagulants were ceased or continued. For other procedures, hemorrhagic complications have not been reported, and case series indicated that they are safe when performed in patients who continue anticoagulants. The results of this review identified reports of adverse effects of ceasing anticoagulants, with serious consequences, including death. The authors of this manuscript concluded that other than for interlaminar procedures, the evidence does not support the view that anticoagulant and antiplatelet medication must be ceased before image-guided spine pain procedures.

\subsection{Prevalence and Risk Assessment of Studies}

Multiple studies have been published assessing the prevalence, as well as the risk of bleeding with interventional techniques (31-34,37,41,42,50-54).

In a survey of practice patterns among interventional pain physicians in 2012, Manchikanti et al (31) showed that the majority of physicians discontinued antithrombotic agents; however, this study also showed that there were a significantly higher number of complications related to thromboembolic events of a total of 162 compared to hemorrhagic complications of a total of 55 in this population.

In a prospective evaluation of bleeding risks for interventional techniques in chronic pain, Manchikanti et al (32) assessed the rates of adverse events in patients undergoing interventional techniques on antithrombotic therapy with cessation or without cessation and compared them to a group of patients without antithrombotic therapy. While the results showed differences in milder complications, there were no reports of hemorrhagic complications requiring any type of treatment. In this assessment, the authors studied all types of procedures with 1,227 of 1,831 continuing aspirin compared to 604 of 1,831 discontinuing them. Similarly, they also studied 100 patients on clopidogrel with continuation, whereas, 226 patients were discontinued. Further, there were 128 patients with aspirin and other agents with continuation and 151 were discontinued. The procedures performed included cervical epidural injections with continued aspirin in 249 patients, thoracic epidural in 30 patients, lumbar interlaminar epidural in 128 patients, lumbar transforaminal in 144 patients, whereas 528 patients for caudal epidural injections, and 148 for percutaneous adhesiolysis. In reference to clopidogrel, it was continued in 10 patients undergoing cervical epidural, one patient with thoracic epidural, 14 patients with lumbar epidural, 44 patients with caudal epidurals, 10 with lumbar transforaminal epidural, and 21 with percutaneous adhesiolysis. There were a large number of facet joint interventions and other treatments.

van Helmond et al (51), in a retrospective review, assessed the safety of low to intermediate risk spine procedures in patients with continued antithrombotic therapy. They identified 490 patients of a total of 2,204 patients on antithrombotic medications which included aspirin $(\mathrm{N}=275), \mathrm{P} 2 \mathrm{Y} 12$ inhibitors $(\mathrm{N}=129)$, warfarin ( $\mathrm{N}$ $=62)$, heparin $(N=10)$, factor $X a$ inhibitors $(N=55)$, and dipyridamole $(N=1)$. The procedures included facet joint nerve blocks and facet joint radiofrequency in all 3 regions and sacroiliac joint injections. The authors concluded that there were no hemorrhagic complications in performing these procedures.

Goodman et al (50) studied the role of anticoagulant and antiplatelet management for spinal procedures in a prospective descriptive study. Out of 4,253 procedures, 197 of them were performed in 74 patients on antiplatelet/anticoagulants, they reported no clinically evident bleeding events for lumbar transforaminal epidural injections $(\mathrm{N}=90)$, facet joint injections $(\mathrm{N}=62)$, lumbar intradiscal procedures $(\mathrm{N}=11)$, lumbar sympathetic blocks $(\mathrm{N}=3)$, sacroiliac injections $(\mathrm{N}=5)$, or in 26 radiofrequency neurotomy procedures. However, similar to van Helmond et al (51), Goodman et al (50) have not performed any epidural injections on patients with continuation of antiplatelet therapy.

Endres et al (42) assessed risks of continuing or discontinuing anticoagulants for patients undergoing interventional procedures. They reported no complications attributable to anticoagulants in 4,766 procedures in which anticoagulants were continued. They mainly performed lumbar transforaminal injections, lumbar medial branch blocks, trigger point injections, and sacroiliac joint blocks, and they concluded that continuation of anticoagulant therapy seems to be safe. They performed interlaminar epidural injections in 25 patients with continuation of Warfarin and 15 patients with continuation of clopidogrel. In addition, they reported 171 patients undergoing sacroiliac joint blocks on Warfarin, 227 patients undergoing trigger point injections, 40 patients with trochanteric bursa injections, and 87 patients with hip joint injections, they also reported 81 patients with clopidogrel undergoing sacroiliac joint blocks, 214 patients with trigger point injections, 50 patients with trochanteric bursa injections, and 52 patients with hip joint injections. 
Warner et al (54) in a manuscript describing bleeding and neurological complications in 58,000 interventional pain procedures showed that preprocedural aspirin or nonsteroidal antiinflammatory drug therapy was prevalent in 17,825 procedures or $30.7 \%$ of the procedures without significant bleeding complications. Out of total 58,066 procedure performed in the study; $22.4 \%$ of the procedures were performed with perioperative administration of aspirin within 7 days, $12.1 \%$ of the patients with administration of nonsteroidal anti-inflammatory drugs within 7 days, $1.6 \%$ of clopidogrel within 7 days. The study also included 3,880 lumbar epidural injections, 304 thoracic interlaminar injections with a large number of epidural injections with over $50 \%$ of the epidural injections not assigned to a region. They concluded that bleeding complications were rare in patients undergoing low or intermediate risk pain procedures even in the presence of antiplatelet medication.

Lagerkranser (52) and Lagerkranser and Lindquist (53) have published extensive review of neuraxial blocks and spinal hematoma in 2 parts from 1994 to 2015 covering demographics, risk factors, diagnosis, treatment, and outcome. They also considered previous reviews published in 1992 (175), 1994 (176), and 1996 (177) case reviews, analyzing 29,61, and 51 cases of spinal hematoma after neuraxial blocks, respectively, between 1906 and 1996. They identified multiple changes in the perioperative management of surgical patients, thromboprophylaxis with multiple newer agents, and multiple published guidelines. They identified 147 published articles, case reports or letters, describing altogether 166 cases relevant for the review. They showed that 64 cases were from Europe, 53 from North America, 4 from South America, 39 from Asia and 6 from Australia. They reported hematoma formation secondary to multiple types of neuraxial blocks, including spinal injections, epidural injections, combined spinal and epidural injections, and spinal cord stimulators. They reported 49 lumbar injections with 12 single shots, 46 thoracic injections all with continuous and 6 cervical locations with 5 single shots secondary to epidural injections. A large number of hematomas appeared after removal of the catheter. In managing chronic pain with epidural injections, they identified 21 hematomas, 17 (5 cervical, 4 thoracic, and 8 lumbar) after epidural injections, and 4 after percutaneous application of spinal cord stimulators. However, they have not identified the number of patients developing hematoma with appropriate cessation of antithrombotic therapy based on recommended guidelines. Overall, they showed that $37 \%$ of the patients who were not on antihemostatic drugs, whereas $63 \%$ were on antihemostatic drugs with 47 of the cases, receiving more than one antihemostatic drug, and 12 receiving 3 such drugs. Further, they also had 6 reports which were indeterminate. Consequently, the number of patients without antithrombotic therapy, but with hematoma formation seems to be almost $40 \%$.

Lagerkranser (52) showed that an annual average of 7.5 published cases of spinal hematoma in the years 1994 to 2015, compared to an average of only 2.5 case reports per year from 1976 to 1993 (176). They also identified that there has been a transition from a male to female dominance among patients suffering from post-neuraxial blockade and spinal hematoma particularly among the elderly women. In addition, guidelines issued around the turn of the century have not been followed by a reduced number of published case reports, even though adherence to the guidelines has increased during the last decade.

The authors identified spinal stenosis as the most common spinal disease in 14 cases with spinal disease reported in 37 cases of 166 cases (52). They identified bloody tap at the introduction of a neuraxial needle or catheter as a major risk factor, but multiple attempts to reach the spinal canal do not seem to increase the risk of spinal hematoma. Their results also showed that $80 \%$ of the patients developing spinal hematoma had severe neurological symptoms with paresis or paralysis. When compared over time, outcomes have improved significantly (52). The results showed that among patients subjected to surgical evacuation of the hematoma, outcomes were best if surgery was performed within 12 hours from the first sign of motor dysfunction. However, even patients operated after more than 24 hours had relatively favorable outcomes. Further, outcomes after surgical evacuation of the epidural hematoma were satisfactory, compared to subdural hematoma, which had poor outcomes. They recommended that suspicion of spinal hematoma calls for the consultation of surgeon without delay. Magnetic resonance imaging (MRI) was the recommended diagnostic tool. Surgical evacuation within 12 hours from the sign of motor dysfunction seems to lead to the best outcome, even though many patients operated as late as after more than 24 hours did regain full motor function (52).

Moeschler et al (34) assessed bleeding complications in patients undergoing percutaneous spinal cord stimulator trials and implantations with retrospective review from 2005 through 2014 of all patients, with as- 
sessment of 642 percutaneous spinal cord procedures, 346 spinal cord stimulator trials, 255 spinal cord stimulation implantations, and 41 revision surgeries. Patients had received aspirin or NSAIDs within 7 days of needle placement for 101 procedures (15.7\%). There were no bleeding or neurological complications identified in this cohort. Consequently, this study showed that there were no risks associated with patients receiving aspirin or other NSAIDs within 7 days of needle placement in approximately $16 \%$ or 100 procedures; however, they warned that further investigations with larger numbers are needed to better define the relationship between periprocedural aspirin and NSAID utilization and bleeding complications.

Petraglia et al (41) also studied the incidence of spinal cord injury in implantation of percutaneous and paddle electrodes for spinal cord stimulation, with analysis of nationwide data, with inclusion of 8,326 patients. They showed overall incidence of spinal cord injury of $2.1 \%$, with incidence of spinal hematoma of $0.71 \%$, which was seen in 59 patients with 41 in percutaneous group with $0.75 \%$ and 18 in paddle lead group with $0.63 \%$. They concluded that while reversible complications may be more common, spinal cord injury as a result of spinal cord stimulation is uncommon. Even though this was a large database, they recommended for more studies to further characterize the mechanisms of injury and outcomes in these patients. They also assessed odds ratio for using antiplatelet or anticoagulant medications within 30 days prior to spinal cord stimulation procedures. They found that the odds of spinal cord injury increased by 2.4 . If the patient took any type of anticoagulant medication within 30 days prior to the procedure they found no significant increase in the odds of spinal cord injury for patients taking aspirin, clopidogrel, or enoxaparin alone.

LaVallee et al (35) studied the prevalence of bleeding complications following ultrasound-guided botulinum toxin injections in patients on anticoagulation or antiplatelet therapy. They reviewed 328 ultrasound guided intramuscular procedures performed in 15 patients with the predominant indication for chemodenervation being spastic paresis secondary to stroke. Of 328 procedures, only 2 subclinical hematomas were detected, resulting in a bleeding complication rate of $0.61 \%$ in this patient population.

Table 3 describes the studies assessing the risk of thrombosis and bleeding with interventional pain management techniques. All but 2 studies in this assessment are related to performing interventional tech- niques without cessation of antithrombotic therapy $(30-34,37,39,41,42,50,51)$. Only 2 studies $(31,52)$ were related to an online physician survey and study of spinal hematoma with neuraxial blocks. Among all the studies, only 2 studies included epidural injections $(32,42)$. All others have performed a large proportion of procedures with low risk or intermediate risk including transforaminal epidural injections. As shown in Table 4, interlaminar procedures were performed to a large extent by Manchikanti et al (32) with inclusion of patients undergoing cervical epidural, thoracic epidural, lumbar epidural, caudal percutaneous adhesiolysis with aspirin, warfarin, clopidogrel, and aspirin plus other drugs. Endres et al (42) also studied lumbar interlaminar epidural injections in 25 patients with continuation of warfarin and 15 patients with continuation of clopidogrel and 2 patients with continuation of cilostazol and enoxaparin. Lagerkranser (52) also reported $37 \%$ of the patients who were not on antithrombotics.

Based on the evidence presented from these studies, it appears that there is no significant difference whether antithrombotic therapy is discontinued or continued in reference to the bleeding. A majority of the authors have studied intermediate and low risk procedures without the inclusion of epidural injections. The only one study reviewing spinal cord stimulation also showed lack of increased risk with continuation of aspirin and other NSAIDs.

\subsection{Reports of Thromboembolic Events}

There have been multiple reports of thromboembolic events with discontinuation of antithrombotics and anticoagulants prior to performance of interventional procedures. Manchikanti et al (31) in assessment of practice patterns of perioperative management of antiplatelet and anticoagulant therapy in interventional pain management reported 162 thromboembolic events compared to 55 serious bleeding complications from epidural hematomas. This study showed thromboembolic events were 3 times more frequent than bleeding complications. Further, they also showed bleeding complications from epidural hematomas were similar whether antiplatelet therapy was continued or discontinued with an occurrence of 26 versus 29 respectively; in this survey the sample sizes were not provided. Consequently, it is difficult to assess exact risk of bleeding complications and similarly thromboembolic events.

Endres et al (42) reported 9 patients with thromboembolic events after cessation of anticoagulant therapy of 1,626 procedures. These complications included 2 
Pain Physician: Guidelines Issue 2019; 22:S75-S128

\begin{tabular}{|c|c|c|c|c|}
\hline & 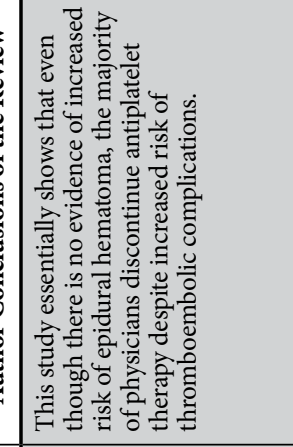 & 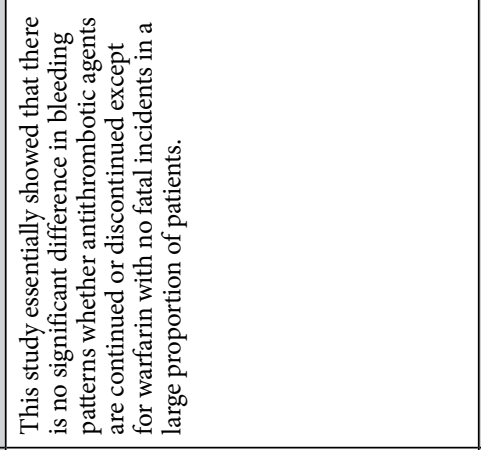 & 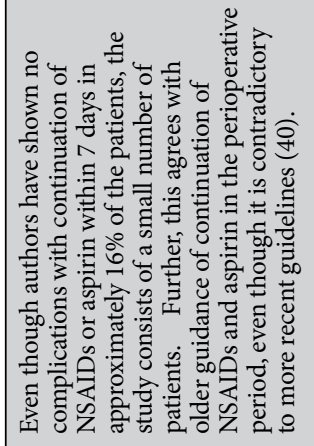 & 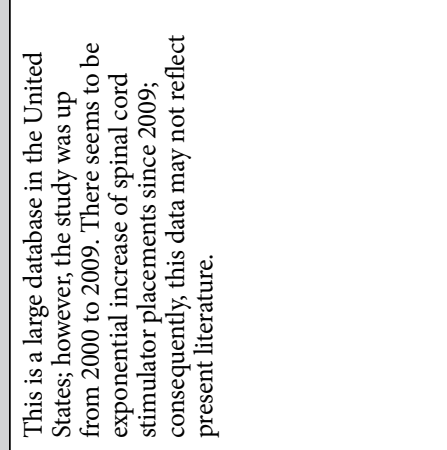 \\
\hline & 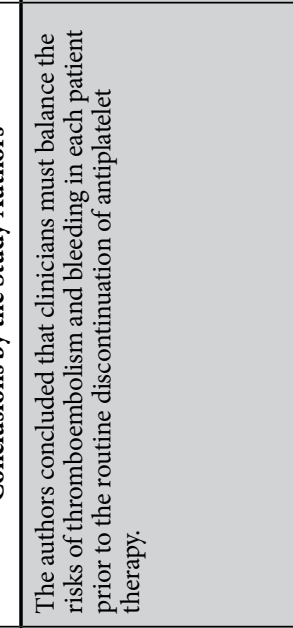 & 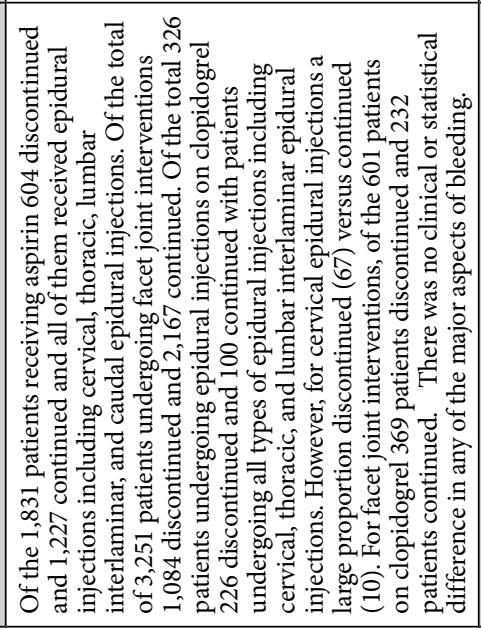 & 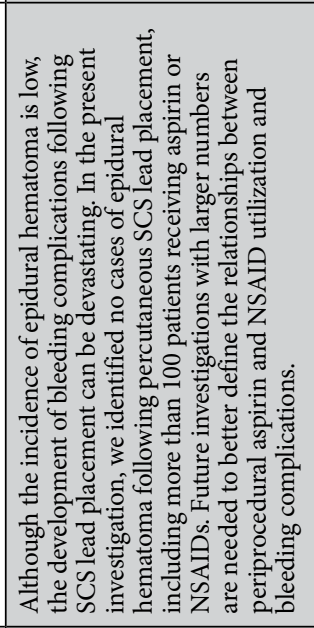 & 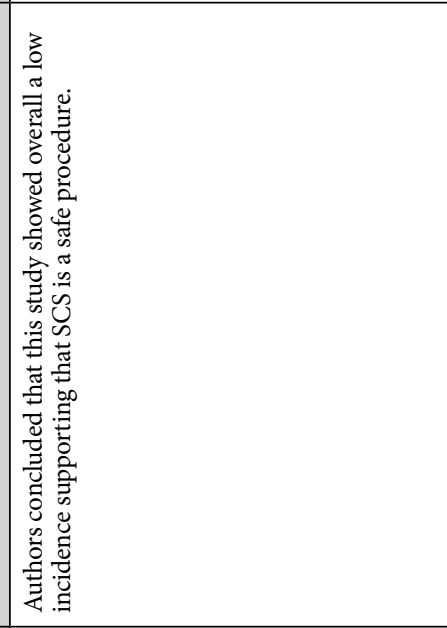 \\
\hline & 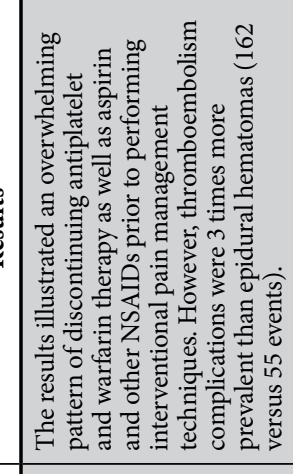 & 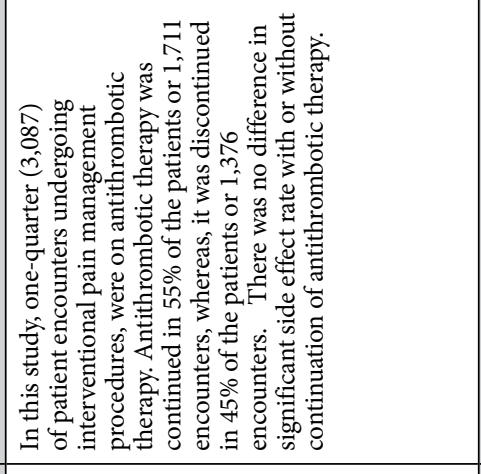 & 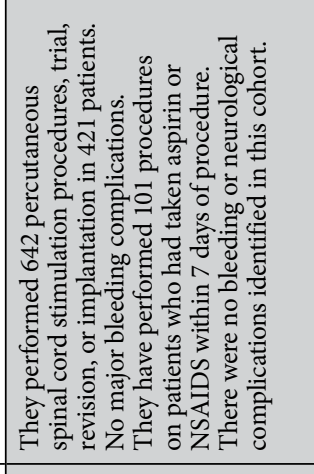 & 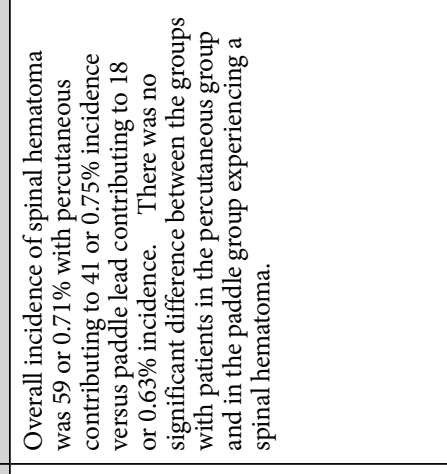 \\
\hline &  & 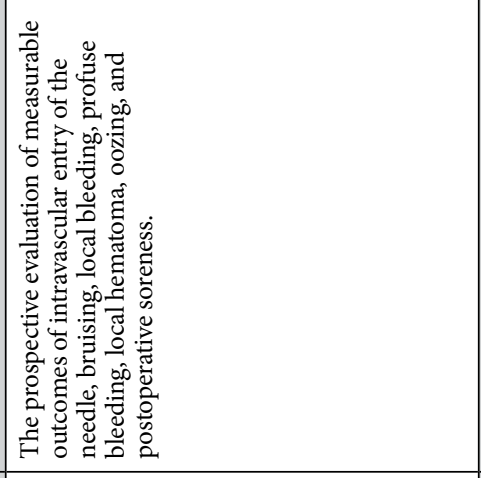 & 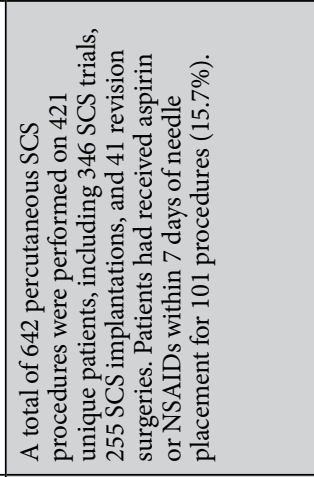 &  \\
\hline & 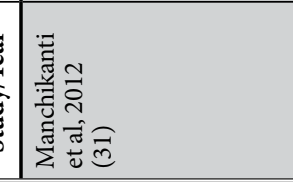 & 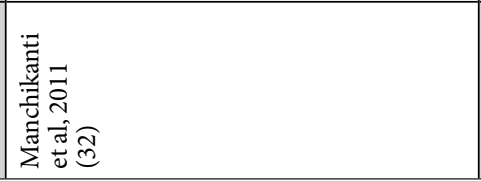 & 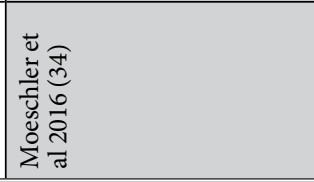 & 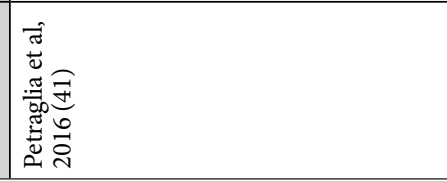 \\
\hline
\end{tabular}




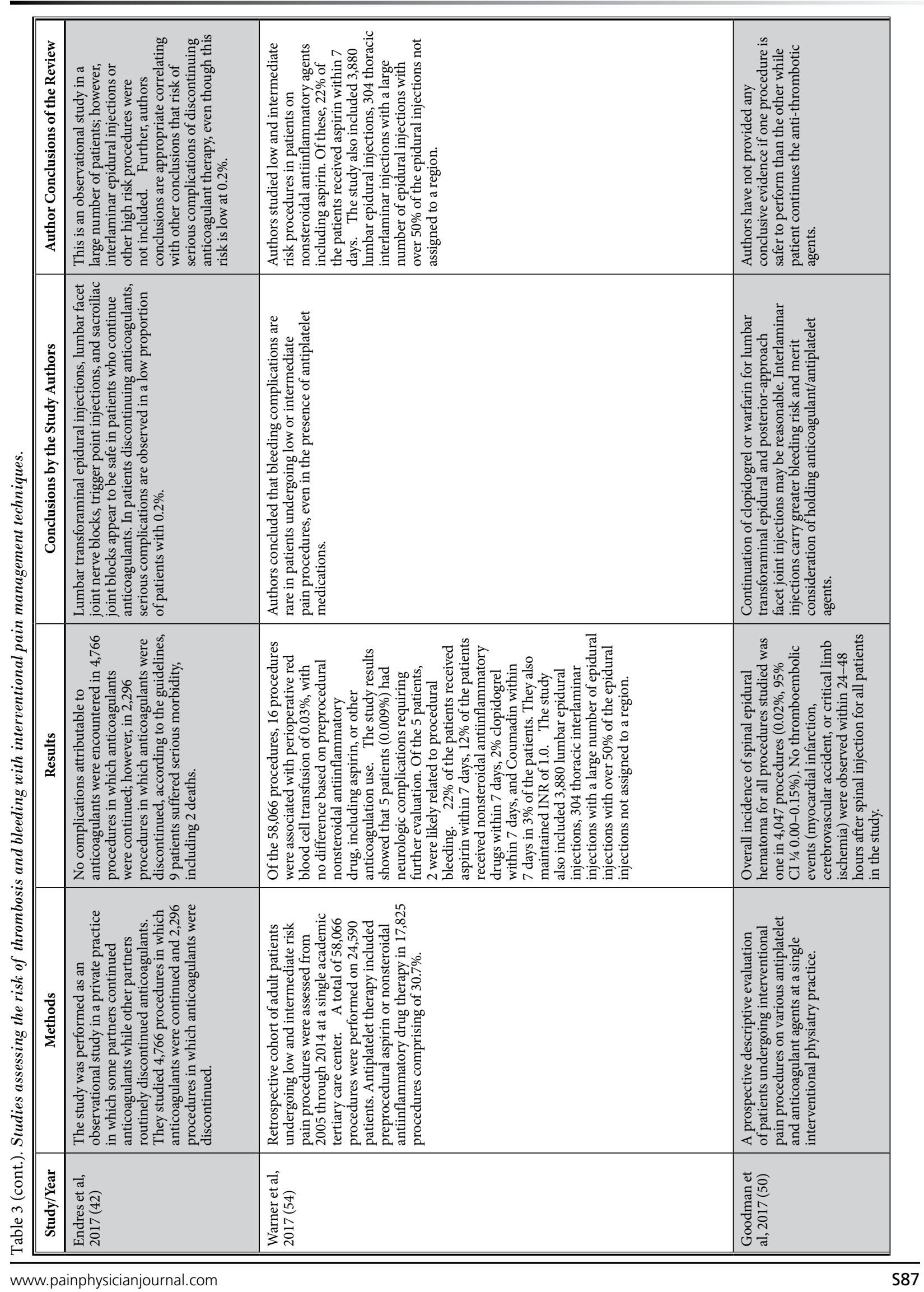







deaths 5 strokes, one pulmonary embolism, and one myocardial infarction in patients when anticoagulants were stopped; however, they have not reported any bleeding complications in patients where anticoagulants were continued, although, with inclusion of a small number of epidural injections with high risk. Kumar et al (178) reported a case of pulmonary embolism after discontinuation of warfarin during spinal cord stimulation trial. Linn et al (179) also reported right middle cerebral artery infarction with persistent left hemiparesis, neglect and dysarthria with L5-S1 epidural steroid injection after discontinuation of warfarin for 9 days preprocedure. Manchikanti et al (138) in providing 2 case reports and literature review described 2 cases of thromboembolic complications with cessation of antithrombotic therapy. Table 5 shows reported thromboembolic and cardiovascular complications related to discontinuation of antiplatelet or anticoagulation therapy.

\subsection{Case Reports of Bleeding Complications}

There were 35 case reports discovered citing epidural hematoma in patients with or without continued antithrombotic therapy during an interventional technique (130-138, 148, 180-204).

Table 6 shows reports of bleeding and epidural hematoma associated with interventional techniques in patients without antithrombotic therapy $\quad(136,138,140,144,180,183,185,190,192-195,197$, 201,203,204,206,208,209), whereas Table 7 shows reports of bleeding in patients with discontinued antithrombotic therapy $(130,133-135,138,139,148,181,187-189,191)$.

Table 8 shows reports of bleeding complications and epidural hematoma in patients with continuation of antiplatelet therapy with interventional techniques. Multiple reports of bleeding complications with continuation of anticoagulant therapy during interventional techniques were identified $(131-133,136,137,182,199,200,202)$.

Table 4. Interlaminar epidural procedures with continuation or discontinuation of antithrombotic therapy.

\begin{tabular}{|c|c|c|c|c|c|c|c|c|c|c|c|c|c|c|c|}
\hline & \multicolumn{3}{|c|}{ Aspirin } & \multicolumn{3}{|c|}{ Warfarin } & \multicolumn{3}{|c|}{ Clopidogrel } & \multicolumn{3}{|c|}{ Aspirin + Others } & \multicolumn{3}{|c|}{$\begin{array}{l}\text { Cilostazol \& } \\
\text { Enoxaparin }\end{array}$} \\
\hline & $D$ & $C$ & $T$ & $D$ & $C$ & $T$ & $D$ & $C$ & $T$ & $D$ & $C$ & $T$ & $D$ & $C$ & $T$ \\
\hline \multicolumn{16}{|l|}{ Manchikanti et al (32) } \\
\hline Cervical Epidural & 161 & 249 & 410 & 12 & 1 & 13 & 67 & 10 & 77 & 34 & 18 & 52 & $N A$ & $N A$ & $N A$ \\
\hline Thoracic Epidural & 19 & 30 & 49 & 1 & 1 & 2 & 7 & 1 & 8 & $N A$ & 5 & 5 & $N A$ & $N A$ & $N A$ \\
\hline Lumbar Epidural & 63 & 128 & 191 & 23 & $N A$ & 23 & 16 & 14 & 30 & 28 & 9 & 37 & $N A$ & $N A$ & $N A$ \\
\hline Percutaneous Adhesiolysis & 68 & 148 & 216 & 24 & $N A$ & 24 & 16 & 21 & 37 & 37 & 32 & 69 & $N A$ & $N A$ & $N A$ \\
\hline Epidurals - Total & 311 & 555 & 866 & 60 & 2 & 62 & 106 & 46 & 152 & 99 & 64 & 163 & $N A$ & $N A$ & $N A$ \\
\hline \multicolumn{16}{|l|}{ Endres et al (42) } \\
\hline Lumbar interlaminar & $N A$ & $N A$ & $N A$ & 169 & 25 & 194 & 69 & 15 & 84 & $N A$ & $N A$ & $N A$ & 0 & 2 & 2 \\
\hline Epidurals - Total & 311 & 555 & 866 & 229 & 27 & 256 & 175 & 61 & 236 & 99 & 64 & 163 & 0 & 2 & 2 \\
\hline
\end{tabular}

None $=$ Not on antithrombotic drugs; $\mathrm{D}=$ discontinued; $\mathrm{C}=$ continued; $\mathrm{T}=$ total

Others: Sacroiliac joint interventions, occipital nerve blocks, intercostal nerve blocks, stellate ganglion block, or lumbar sympathetic blocks

Table 5. Thromboembolic and cardiovascular complications related to discontinuation of antiplatelet or anticoagulation therapy.

\begin{tabular}{|c|c|c|}
\hline Study & Type of study & Complications \\
\hline Endres et al (42) & $\begin{array}{l}\text { Observational report of interventional } \\
\text { techniques }\end{array}$ & $\begin{array}{l}\text { - } 2 \text { patients died } \\
\text { - } 5 \text { suffered strokes } \\
\text { - } 1 \text { suffered pulmonary embolism } \\
\text { - } 1 \text { suffered myocardial infarction }\end{array}$ \\
\hline Kumar et al (178) & $\begin{array}{l}\text { Case report of dorsal column stimulator } \\
\text { trial }\end{array}$ & - Pulmonary embolism without lasting complications \\
\hline Linn et al (179) & $\begin{array}{l}\text { Case report of L5/S1 epidural steroid } \\
\text { injection }\end{array}$ & $\begin{array}{l}\text { - Right middle cerebral artery infarction with persistent left } \\
\text { hemiparesis, neglect, and dysarthria }\end{array}$ \\
\hline Manchikanti et al (31) & Online survey & $\begin{array}{l}\text { - Reports of epidural hematoma: } 55 \\
\text { - Reports of thromboembolic complications: } 162\end{array}$ \\
\hline Manchikanti et al (138) & $\begin{array}{l}\text { Case report and literature review of } \\
\text { interventional techniques }\end{array}$ & $\begin{array}{l}\text { - } 2 \text { cases of thromboembolic complications with cessation of } \\
\text { antithrombotic therapy. }\end{array}$ \\
\hline
\end{tabular}


Pain Physician: Guidelines Issue 2019; 22:S75-S128

Table 6. Reports of bleeding and epidural hematoma associated without antithrombotic therapy with interventional techniques.

\begin{tabular}{|c|c|c|}
\hline Study/Year & Case Report & Conclusions \\
\hline $\begin{array}{l}\text { Swicegood et al, } \\
2017 \text { (136) }\end{array}$ & $\begin{array}{l}\text { Authors reported a cervical epidural hematoma in a } 41 \text {-year-old } \\
\text { Caucasian female with controlled hypertension, but with no drug therapy } \\
\text { contributing to bleeding. She received uneventful epidural injection and } \\
\text { developed neurological dysfunction necessitating surgical decompression. } \\
\text { She recovered without residual dysfunction. }\end{array}$ & $\begin{array}{l}\text { Epidural hematoma developed in a patient without } \\
\text { antithrombotic or anticoagulant therapy. Authors } \\
\text { described this case of epidural hematoma in a patient } \\
\text { with no risk factors or anticoagulant or antiplatelet } \\
\text { therapy. }\end{array}$ \\
\hline $\begin{array}{l}\text { Manchikanti et al, } \\
2017 \text { (138) }\end{array}$ & $\begin{array}{l}\text { Authors reported a case of } 61 \text {-year-old female without risk factors or } \\
\text { anticoagulant therapy. Epidural injection was performed in the cervical } \\
\text { spine without difficulty. Patient developed symptomatology leading to the } \\
\text { diagnosis of cervical epidural hematoma within } 3 \text { hours after the procedure } \\
\text { undergoing surgical intervention due to progressive neurological } \\
\text { dysfunction. }\end{array}$ & $\begin{array}{l}\text { Epidural hematoma occurred after required period } \\
\text { to discontinue aspirin. This patient had no other risk } \\
\text { factors or other anticoagulant therapy. Patient was } \\
\text { also successfully managed conservatively without } \\
\text { surgical intervention. Patient developed epidural } \\
\text { hematoma without any risk factors or anticoagulant } \\
\text { therapy. }\end{array}$ \\
\hline $\begin{array}{l}\text { Manchikanti et al, } \\
2018(140)\end{array}$ & $\begin{array}{l}\text { Cervical epidural hematoma was reported in a healthy } 43 \text {-year-old } \\
\text { functioning female patient without overt risk factors for procedural } \\
\text { hemorrhagic complications including baseline coagulopathy, baseline } \\
\text { dysfunction, and intake of anticoagulants. There were no technical } \\
\text { difficulties in performing the procedure. Patient developed } \\
\text { symptomatology leading to the diagnosis of cervical and thoracic epidural } \\
\text { hematoma with progressive neurological dysfunction necessitating surgical } \\
\text { decompression. }\end{array}$ & $\begin{array}{l}\text { Authors concluded that epidural hematoma may } \\
\text { happen in cervical epidural injections considered } \\
\text { as high risk procedure without antiplatelet or } \\
\text { anticoagulant therapy and also without any risk } \\
\text { factors. }\end{array}$ \\
\hline $\begin{array}{l}\text { Berrigan et al, } \\
2018 \text { (144) }\end{array}$ & $\begin{array}{l}\text { Cervical epidural hematoma was reported in a } 62 \text {-year-old healthy female } \\
\text { patient after dry needling in cervical and thoracic musculature. Patient } \\
\text { developed neurological dysfunction leading to the diagnosis of cervical and } \\
\text { thoracic epidural hematoma confirmed by MRI. Due to stable neurological } \\
\text { function, surgical intervention was deferred. She was managed with } \\
\text { conservative management without residual dysfunction. }\end{array}$ & $\begin{array}{l}\text { Authors report an epidural hematoma with dry } \\
\text { needling, which is considered as extremely unusual } \\
\text { in a patient without risk factors or antiplatelet or } \\
\text { anticoagulant therapy. }\end{array}$ \\
\hline $\begin{array}{l}\text { Desai \& Dua, } \\
2014(180)\end{array}$ & $\begin{array}{l}\text { This is a case report of a 72-year-old female undergoing right } \\
\text { transforaminal epidural injection at L3 and L4. Four days after the } \\
\text { injection patient reported progressive right lower extremity weakness, } \\
\text { worsening sensory loss, and ambulatory dysfunction. An MRI with } \\
\text { gadolinium enhancement showed focal abnormal signal with involvement } \\
\text { of the right L4-5 neuroforamina that extended slightly far laterally, } \\
\text { consistent with a small hematoma, affecting L4 nerve root. There was no } \\
\text { history of coagulopathy. }\end{array}$ & $\begin{array}{l}\text { This case report shows that though extremely rare, } \\
\text { perineural or foraminal hematoma may occur as } \\
\text { a serious complication of transforaminal epidural } \\
\text { injection, even in the setting of a standardized } \\
\text { procedure. }\end{array}$ \\
\hline Ghaly, 2001 (183) & $\begin{array}{l}\text { A 56-year old man who developed Brown-Séquard syndrome from a spinal } \\
\text { epidural hematoma after fluoroscopically-guided cervical steroid injection. } \\
\text { The patient reported immediate sharp shooting pain in the upper } \\
\text { extremities on introduction of epidural Tuohy needle. Within half an hour, } \\
\text { a neurological deficit occurred at C7/8 and right Brown-Séquard syndrome } \\
\text { developed. MRI showed C6 to T2 spinal epidural hematoma with cord } \\
\text { compression. Emergency spinal bilateral decompressive laminectomies } \\
\text { and evacuation of spinal hematoma were performed within an expected } \\
\text { delay of } 10 \text { hours from the onset of neurological deficit from C6 to T12. }\end{array}$ & $\begin{array}{l}\text { Patient developed epidural hematoma without any } \\
\text { risk factors or anticoagulant therapy. }\end{array}$ \\
\hline $\begin{array}{l}\text { Stoll \& Sanchez, } \\
2002(185)\end{array}$ & $\begin{array}{l}\text { A healthy } 34 \text {-year old man with no evidence of coagulopathy and not } \\
\text { taking antiplatelet medication suddenly had onset of acute cervical } \\
\text { myelopathy from a large cervical epidural hematoma } 8 \text { days after cervical } \\
\text { epidural steroid injection. The patient developed a Brown-Séquard type } \\
\text { of myelopathy manifesting by severe weakness of the left arm and leg and } \\
\text { right-sided numbness and loss of temperature appreciation. The diagnosis } \\
\text { was made by CT scan. Following prompt surgical evaluation of the clot, the } \\
\text { patient made a near complete recovery. }\end{array}$ & $\begin{array}{l}\text { The authors concluded that this case illustrated } \\
\text { that epidural hematoma may occur in the absence } \\
\text { of known risk factors. The delayed onset and the } \\
\text { absence of risk factors have implications for the } \\
\text { use of epidural steroid injection in chronic pain } \\
\text { management. }\end{array}$ \\
\hline $\begin{array}{l}\text { Lee et al, } 2011 \\
(190)\end{array}$ & $\begin{array}{l}\text { A } 58 \text {-year old woman presented with quadriparesis and neck pain after } \\
\text { dry needling. MRI of the spine revealed a hyperintense mass in the T2 } \\
\text { weighted at C2-T2 level, which proved to be an epidural hematoma. The } \\
\text { diagnosis was made with MRI and decompression was carried out. The } \\
\text { patient recovered completely. There were no risk factors and the patient } \\
\text { was not on antiplatelet therapy. }\end{array}$ & $\begin{array}{l}\text { The authors concluded the spinal hematoma caused } \\
\text { by dry needling in this case was probably the result of } \\
\text { unintentional needling of the spinal canal, similar to } \\
\text { that caused by central neural blockade. }\end{array}$ \\
\hline $\begin{array}{l}\text { Ozdemir et al, } \\
2007 \text { (193) }\end{array}$ & $\begin{array}{l}\text { Epidural steroid injection was performed with a \#18 gauge Tuohy needle } \\
\text { which revealed a dural puncture in a } 40 \text {-year old male. The second attempt } \\
\text { at L3/4 level was successful. MRI showed a right frontal subdural } \\
\text { hematoma. His headache was relieved after strict bedrest, intravenous } \\
\text { hydration, and analgesics. The patient was discharged with full recovery } \\
\text { after one week without neurological dysfunction. }\end{array}$ & $\begin{array}{l}\text { The authors concluded that intracranial subdural } \\
\text { hematoma for accidental dural puncture during } \\
\text { epidural steroid injection is a rare complication, even } \\
\text { though there were no risk factors in this patient. }\end{array}$ \\
\hline
\end{tabular}


Table 6 (cont.). Reports of bleeding and epidural hematoma associated without antithrombotic therapy with interventional techniques.

\begin{tabular}{|c|c|c|}
\hline Study/Year & Case Report & Conclusions \\
\hline $\begin{array}{l}\text { Lee et al, } 2007 \\
\text { (195) }\end{array}$ & $\begin{array}{l}\text { A healthy } 38 \text {-year-old woman underwent a series of right transforaminal } \\
\text { epidural injections at the C7-T1 level. Approximately } 4 \text { days after the final } \\
\text { injection, she awakened with severe upper thoracic pain and progressive } \\
\text { loss of sensation in the lower extremities. MRI of the spine showed a large } \\
\text { hematoma extending from T1 to T5. The patient underwent surgical } \\
\text { decompression. Within } 6 \text { months patient regained full strength and } \\
\text { sensation in both lower extremities. }\end{array}$ & $\begin{array}{l}\text { The authors cautioned that the physician should } \\
\text { be aware that symptoms from a slowly developing } \\
\text { epidural hematoma can present even days after an } \\
\text { injection. }\end{array}$ \\
\hline $\begin{array}{l}\text { Domenicucci et } \\
\text { al, } 2017 \text { (197) }\end{array}$ & $\begin{array}{l}\text { A report of acute spinal epidural hematoma after acupuncture extending } \\
\text { from C2 through T12. Due to rapid improvement with the patients' } \\
\text { neurological symptoms, conservative treatment was adopted with excellent } \\
\text { long-term results. }\end{array}$ & Acupuncture may produce epidural hematoma. \\
\hline $\begin{array}{l}\text { Keane et al, } 1993 \\
\text { (201) }\end{array}$ & $\begin{array}{l}\text { A case report of a } 65 \text {-year-old female with development of epidural } \\
\text { hematoma at T5-T6 several hours after acupuncture. Conservative } \\
\text { management resulted in complete recovery. }\end{array}$ & Acupuncture may produce epidural hematoma. \\
\hline $\begin{array}{l}\text { Kim \& Park, } 2015 \\
(203)\end{array}$ & $\begin{array}{l}\text { A 39-year-old female underwent cervical epidural injection at C6 under } \\
\text { fluoroscopic guidance. Five days after epidural injection she complained } \\
\text { of mild headache that was increasing in the upright position with a normal } \\
\text { CT scan. At this time, she was treated with conservative management for } \\
\text { post dural puncture headache. One month later, she presented with } \\
\text { a severe headache that was not relieved by analgesic medication, which } \\
\text { changed in character from being positional to non-positional during the } \\
\text { preceding month. Brain magnetic resonance imaging revealed a chronic } \\
\text { subdural hematoma along the left convexity. Emergency Burr Hole } \\
\text { drainage was performed and the headache abated. }\end{array}$ & $\begin{array}{l}\text { This report indicated that an intracranial chronic } \\
\text { subdural hematoma presenting with intractable } \\
\text { headache after cervical epidural steroid injection } \\
\text { should be considered a possible complication. In } \\
\text { addition, the event of an intractable and changing } \\
\text { post dural puncture headache after epidural injection } \\
\text { suggests further evaluation for diagnosis of an } \\
\text { intracranial hematoma. }\end{array}$ \\
\hline $\begin{array}{l}\text { Takawira et al, } \\
2012 \text { (204) }\end{array}$ & $\begin{array}{l}\text { A 52-year old male patient underwent spinal cord trial stimulation } \\
\text { placement from T8 through T10 levels bilaterally with epidural entry at } \\
\text { T12 and L1 interspace. } 72 \text { hours after the placement with good pain relief, } \\
\text { he suddenly noticed relocation of stimulation to his right flank, with } \\
\text { an abrupt onset of } 10 / 10 \text { burning lower back pain radiating down both } \\
\text { lateral thighs and accompanied by inability to lift his knees. The patient } \\
\text { also exhibited neurological deficits and loss of rectal tone. The trial leads } \\
\text { were immediately removed and an MRI was performed. This showed } \\
\text { an epidural or subdural fluid collection surrounding and compressing } \\
\text { the thecal sac and spinal cord, extending from C7 to L3, which was } \\
\text { interpreted as possibly a rapidly developing epidural hematoma. The } \\
\text { epidural hematoma was a "thin spread" which was postulated as secondary } \\
\text { to dislocation of the lead rather than trauma of the insertion. Epidural } \\
\text { hematoma resolved rapidly and no surgical intervention was required with } \\
\text { full recovery. }\end{array}$ & $\begin{array}{l}\text { This is another case of spinal cord trial stimulation } \\
\text { causing epidural hematoma with full recovery, but } \\
\text { may cause severe problems. The authors noted } \\
\text { that based on the retrospective analysis using a } \\
\text { Manufacturer and User Facility Device Experience } \\
\text { (MAUDE) database, the incidence of epidural } \\
\text { hematoma was about } 0.19 \% \text {. }\end{array}$ \\
\hline $\begin{array}{l}\text { Smith et al, } 2010 \\
\text { (206) }\end{array}$ & $\begin{array}{l}\text { The authors reported } 2 \text { cases of epidural hematoma out of } 4 \text { complications } \\
\text { related to spinal cord stimulations admitted to an acute spinal cord } \\
\text { rehabilitation hospital over a } 4 \text {-month period. The first patient with } \\
\text { hematoma after placement of stimulator trial leads developed acute new } \\
\text { mid back pain associated with rapid progressive weakness and motor } \\
\text { loss to his bilateral lower extremities on day } 5 \text { associated with urinary } \\
\text { retention. The pattern of weakness began in the right lower extremity and } \\
\text { then progressed to the left lower extremity. A thoracic CT myelogram } \\
\text { and CT of the thoracic spine with intrathecal contrast showed an epidural } \\
\text { hematoma which extended } 2 \text { levels above the area of the spinal cord } \\
\text { stimulator placement. The patient was not on any anticoagulants and all } \\
\text { the studies were normal. On postoperative day } 5 \text {, the patient underwent } \\
\text { a thoracic T8/9 laminectomy with excision of epidural hematoma and } \\
\text { removal of spinal cord stimulator electrodes. The patient developed } \\
\text { permanent spinal cord injury }\end{array}$ & $\begin{array}{l}\text { Spinal cord hematoma developing after a trial } \\
\text { without any risk factors. Recovery was poor after } \\
\text { acute rehabilitation. }\end{array}$ \\
\hline $\begin{array}{l}\text { Smith et al, } 2010 \\
(206)\end{array}$ & $\begin{array}{l}\text { The authors reported } 2 \text { cases of epidural hematoma out of } 4 \text { complications } \\
\text { related to spinal cord stimulations admitted to an acute spinal cord } \\
\text { rehabilitation hospital over a } 4 \text {-month period. The authors reported a } \\
\text { second patient, a 66-year old female with a history of chronic low back } \\
\text { pain with stimulator leads placed in a patient with moderate to severe canal } \\
\text { stenosis at L1/2 and L2/3 with epidural hematoma and air spanning T9- } \\
\text { L2/3 and mass effect increasing the canal narrowing of the L1/2 and L2/3 } \\
\text { levels. She underwent decompressive thoracic and lumbar laminectomies } \\
\text { of T11-L2 levels. After acute inpatient rehabilitation stay, she recovered } \\
\text { full motor strength in bilateral lower extremities. However, she was } \\
\text { independent with limited community ambulation and had full bladder and } \\
\text { bowel function recovery. She was diagnosed with spinal cord injury at T7. }\end{array}$ & $\begin{array}{l}\text { Spinal cord hematoma developing after trial in a } \\
\text { patient with severe spinal stenosis; however, without } \\
\text { any antithrombotic therapy with moderate recovery } \\
\text { after acute rehabilitation. }\end{array}$ \\
\hline
\end{tabular}


Table 6 (cont.). Reports of bleeding and epidural hematoma associated without antithrombotic therapy with interventional techniques.

\begin{tabular}{|l|l|l|}
\hline \multicolumn{1}{|c|}{ Study/Year } & \multicolumn{1}{|c|}{ Case Report } & \multicolumn{1}{c|}{ Conclusions } \\
\hline $\begin{array}{l}\text { Chen et al, 1997 } \\
(208)\end{array}$ & $\begin{array}{l}\text { A case of a 48-year-old female developing epidural hematoma one week } \\
\text { after acupuncture at L1-2. Patient was managed conservatively with } \\
\text { complete recovery. }\end{array}$ & Acupuncture may produce epidural hematoma. \\
\hline $\begin{array}{l}\text { Eftekhar et al, } \\
2005(192)\end{array}$ & $\begin{array}{l}\text { A 74-year-old male patient developed epidural hematoma 2 days after } \\
\text { acupuncture at L2-3. Patient underwent laminectomy with complete } \\
\text { recovery. }\end{array}$ & Acupuncture may produce epidural hematoma. \\
\hline $\begin{array}{l}\text { Chen et al, 2006 } \\
(194)\end{array}$ & $\begin{array}{l}\text { A 30-year-old male patient with upper back pain developed epidural } \\
\text { hematoma from C7-T3 one hour after acupuncture. Patient underwent } \\
\text { laminectomy with complete recovery. }\end{array}$ & Acupuncture may produce epidural hematoma. \\
\hline $\begin{array}{l}\text { Nam et al, 2010 } \\
(209)\end{array}$ & $\begin{array}{l}\text { A 60-year-old male patient with back pain developed epidural hematoma } \\
\text { 5 days after acupuncture from L4-S1. Patient underwent laminectomy } \\
\text { with complete recovery. }\end{array}$ & Acupuncture may produce epidural hematoma. \\
\hline
\end{tabular}

Table 7. Reports of bleeding and epidural hematoma in patients after discontinuation of antithrombotic therapy after interventional techniques.

\begin{tabular}{|c|c|c|c|c|}
\hline Study & $\begin{array}{c}\text { Antithrombotic/ } \\
\text { Anticoagulant }\end{array}$ & $\begin{array}{l}\text { Number of } \\
\text { Days Stopped } \\
\text { Prior to } \\
\text { Procedure }\end{array}$ & Case Report & Conclusion \\
\hline $\begin{array}{l}\text { Benyamin et } \\
\text { al (130) }\end{array}$ & Clopidogrel & 12 days & $\begin{array}{l}\text { Acute epidural hematoma formation was reported in cervical } \\
\text { spine after interlaminar epidural steroid injection despite } \\
\text { discontinuation of clopidogrel for } 12 \text { days. Procedure } \\
\text { was performed atraumatically between C7 and T1 under } \\
\text { fluoroscopic guidance and contrast injection. The patient } \\
\text { started complaining of severe pain immediately after transfer } \\
\text { to the recovery area. The patient underwent an expedited } \\
\text { cervical spine MRI identifying a large epidural hematoma } \\
\text { which was surgically decompressed with full recovery. } \\
\text { Patient was given } 30 \mathrm{mg} \text { of ketorolac intramuscularly for pain. }\end{array}$ & $\begin{array}{l}\text { Epidural hematoma occurred } \\
\text { in a patient after stopping of } \\
\text { clopidogrel } 12 \text { days prior to } \\
\text { the procedure. Ketorolac } \\
\text { may contribute to exacerbation } \\
\text { of hematoma. However, the } \\
\text { patient was already significantly } \\
\text { symptomatic prior to } \\
\text { administration of ketorolac. }\end{array}$ \\
\hline $\begin{array}{l}\text { Giberson et al } \\
\text { (133) }\end{array}$ & $\begin{array}{l}\text { Low dose aspirin } \\
81 \mathrm{mg} \text { and other } \\
\text { NSAIDs }\end{array}$ & One week & $\begin{array}{l}\text { This is a case report of a 70-year old patient undergoing } \\
\text { spinal cord stimulator trial lead placement. He discontinued } \\
\text { low dose aspirin } 81 \mathrm{mg} \text { and other NSAIDs one week before } \\
\text { the trial. After the removal of the trial after } 4 \text { days, the } \\
\text { patient developed acute onset of burning lower thoracic pain } \\
\text { and lower extremity weakness and spasms. An emergent } \\
\text { MRI image revealed epidural hematoma extending from } \\
\text { T8 to L3 with significant cord compression. The patient } \\
\text { underwent an emergent T8 to T11 laminectomy and } \\
\text { evacuation of the hematoma. He had complete resolution of } \\
\text { his symptoms and was discharged home in good condition. }\end{array}$ & $\begin{array}{l}\text { The authors reported, along } \\
\text { with this case, another case } \\
\text { where the patient took aspirin } \\
\text { the day of the removal of the } \\
\text { leads and developed hematoma. } \\
\text { Consequently, they concluded } \\
\text { aspirin must be discontinued. } \\
\text { However, it is puzzling that this } \\
\text { patient was on aspirin; however, } \\
\text { he discontinued } 7 \text { days prior to } \\
\text { the procedure. }\end{array}$ \\
\hline $\begin{array}{l}\text { Page et al } \\
(134)\end{array}$ & Warfarin & $\begin{array}{l}\text { Discontinued } \\
7 \text { days } \\
\text { earlier with } \\
\text { preoperative } \\
\text { INR of } 1.0\end{array}$ & $\begin{array}{l}\text { This case report involves a } 67-\text {-year old woman undergoing } \\
\text { interlaminar epidural injection with significant spinal stenosis } \\
\text { at multiple levels undergoing interlaminar epidural injection } \\
\text { with an } \# 18 \text { gauge Tuohy needle utilizing a paramedian } \\
\text { approach with a single attempt. The patient developed } \\
\text { weakness in legs the next day, } 18 \text { hours after the procedure. } \\
\text { She had minimal relief with pain after the procedure. That } \\
\text { evening around } 11: 30 \text { pm, she was taken to the emergency } \\
\text { room with weakness and inability to completely empty the } \\
\text { bladder with an emergent MRI, which showed epidural } \\
\text { hematoma from L3 to L5 with significant compression of the } \\
\text { cauda equina. The patient underwent laminectomy within } \\
4 \text { hours of arrival to the emergency room. Total time from } \\
\text { injection to the operating room was approximately } 35 \text { hours. } \\
\text { She developed a permanent foot drop. }\end{array}$ & $\begin{array}{l}\text { The authors described presence } \\
\text { of spinal stenosis and the } \\
\text { interlaminar approach seem to } \\
\text { be significant risk factors in this } \\
\text { patient. The epidural hematoma } \\
\text { developed despite discontinuation } \\
\text { of warfarin } 7 \text { days before the } \\
\text { surgery. }\end{array}$ \\
\hline $\begin{array}{l}\text { Swicegood et } \\
\text { al (135) }\end{array}$ & Aspirin, $81 \mathrm{mg}$ & 7 days & $\begin{array}{l}\text { Authors reported a thoracic epidural hematoma after } \\
\text { interlaminar epidural injection in a patient on } 81 \mathrm{mg} \\
\text { aspirin therapy which was discontinued } 7 \text { days prior. } \\
\text { Epidural injection was performed at T10-11 leading to } \\
\text { symptomatology developing of neurological dysfunction } \\
\text { within } 2 \text { hours. Surgical decompression was carried out with } \\
\text { rapid recovery. }\end{array}$ & $\begin{array}{l}\text { Epidural hematoma developed } \\
\text { despite stopping low dose aspirin } \\
81 \mathrm{mg} \text { within the required time } \\
\text { of } 7 \text { days. }\end{array}$ \\
\hline
\end{tabular}


Table 7 (cont.). Reports of bleeding and epidural hematoma in patients after discontinuation of antithrombotic therapy after interventional techniques.

\begin{tabular}{|c|c|c|c|c|}
\hline Study & $\begin{array}{l}\text { Antithrombotic/ } \\
\text { Anticoagulant }\end{array}$ & $\begin{array}{c}\text { Number of } \\
\text { Days Stopped } \\
\text { Prior to } \\
\text { Procedure }\end{array}$ & Case Report & Conclusion \\
\hline $\begin{array}{l}\text { Manchikanti } \\
\text { et al (138) }\end{array}$ & Aspirin & 9 days & $\begin{array}{l}\text { A case of cervical epidural hematoma in a } 68 \text {-year-old } \\
\text { Caucasian female patient was presented. Patient was on } 81 \\
\text { mg of aspirin which was discontinued } 9 \text { days prior to the } \\
\text { procedure. Following an uneventful cervical interlaminar } \\
\text { epidural injection she developed symptomology with the } \\
\text { diagnosis leading to epidural hematoma confirmed by } \\
\text { MRI. She was managed conservatively with improving } \\
\text { symptomatology and recovered completely. }\end{array}$ & $\begin{array}{l}\text { Epidural hematoma occurred } \\
\text { after required period to } \\
\text { discontinue aspirin. This patient } \\
\text { had no other risk factors or other } \\
\text { anticoagulant therapy. Patient } \\
\text { was also successfully managed } \\
\text { conservatively without surgical } \\
\text { intervention. }\end{array}$ \\
\hline $\begin{array}{l}\text { Kim et al } \\
(139)\end{array}$ & $\begin{array}{l}\text { Clopidogrel, } \\
\text { aspirin, and } \\
\text { beraprost }\end{array}$ & 7 days & $\begin{array}{l}\text { Authors reported a lumbar epidural hematoma with late } \\
\text { onset, } 3 \text { weeks after the performance of epidural steroid } \\
\text { injection in a patient with spinal stenosis at L4-5 interspace. } \\
\text { Patient was on clopidogrel, aspirin, and beraprost following } \\
\text { infrarenal abdominal aortic aneurysm repair. Clopidogrel } \\
\text { and aspirin were stopped } 7 \text { days prior to the epidural } \\
\text { injection. Symptomatology developed } 3 \text { weeks after the } \\
\text { epidural injection with formation of a large hematoma to } \\
\text { cause severe thecal compression. Patient was managed } \\
\text { conservatively without residual complications. }\end{array}$ & $\begin{array}{l}\text { Epidural hematoma with late } \\
\text { onset } 3 \text { weeks after the procedure } \\
\text { in a patient after withholding } \\
\text { appropriately clopidogrel and } \\
\text { aspirin for } 7 \text { days. The authors } \\
\text { also identified spinal stenosis as a } \\
\text { contributing risk factor. }\end{array}$ \\
\hline $\begin{array}{l}\text { Caputo et al } \\
\text { (148) }\end{array}$ & Dabigatran & 7 days & $\begin{array}{l}\text { A } 70 \text {-year old patient underwent lumbar interlaminar } \\
\text { epidural injection under CT guidance at L4/5. Dabigatran } \\
\text { was started } 24 \text { hours after the injection. The patient had } \\
\text { complete resolution of the symptoms. } 48 \text { hours after the } \\
\text { injection, the patient started developing numbness in both } \\
\text { lower extremities and had nearly complete paraplegia of the } \\
\text { bilateral lower extremities. An emergent MRI showed an } \\
\text { acute stenotic lesion, which was not present on the previous } \\
\text { MRI. The patient was immediately decompressed. The } \\
\text { patient was treated with multiple units of packed red blood } \\
\text { cells prior to decompression. On surgical exposure, there } \\
\text { was a large hematoma from L3-L5. Surgical evacuation of the } \\
\text { hematoma was carried out with full neurological recovery } 6 \\
\text { months after surgery. }\end{array}$ & $\begin{array}{l}\text { The authors concluded that } \\
\text { there is no reversal protocol } \\
\text { for dabigatran. Dabigatran was } \\
\text { stopped } 7 \text { days prior, which } \\
\text { is longer than recommended } \\
\text { duration. However, it was started } \\
\text { one day after the procedure, } \\
\text { which seems to have resulted in } \\
\text { hematoma formation. }\end{array}$ \\
\hline $\begin{array}{l}\text { Shanthanna } \\
\text { \& Park et al } \\
\text { (181) }\end{array}$ & Warfarin & $\begin{array}{l}\text { Stopped for } \\
4 \text { days with } \\
\text { an INR of } 1.2 \\
\text { on the day } \\
\text { of epidural } \\
\text { injection }\end{array}$ & $\begin{array}{l}\text { A } 65 \text {-year-old male patient was treated with lumbar epidural } \\
\text { injection at L3-4 in the sitting position with a second attempt } \\
\text { which was atraumatic. Patient reported severe back } \\
\text { pain and inability to stand } 20 \text { minutes after the procedure. } \\
\text { An MRI scan performed within } 3 \text { hours of the patient's } \\
\text { symptomatology revealed a localized dorsal/lateral thoracic } \\
\text { epidural hematoma at T10 to T12. After neurosurgical } \\
\text { referral, conservative management was provided with } \\
\text { significant improvement within a day without having } \\
\text { sustained any neurological deficit. An MRI done at the } \\
\text { follow-up visit, a week later, showed a resolving hematoma. }\end{array}$ & $\begin{array}{l}\text { Epidural hematoma developed } \\
\text { after appropriate discontinuation } \\
\text { of Warfarin and ideal INR of } \\
1.2 \text { within } 20 \text { minutes after the } \\
\text { epidural injection. Epidural } \\
\text { injection was at L3-4 level; } \\
\text { however, hematoma was at T10 to } \\
\text { T12. Authors concluded that the } \\
\text { situation calls for optimization } \\
\text { of all the relevant patient factors } \\
\text { including anticoagulant therapy, } \\
\text { use of appropriate technique, } \\
\text { and the appropriate imaging } \\
\text { modalities. However, spinal } \\
\text { stenosis has been described as a } \\
\text { significant risk factor to develop } \\
\text { epidural hematoma with epidural } \\
\text { injections. }\end{array}$ \\
\hline
\end{tabular}


Table 7 (cont.). Reports of bleeding and epidural hematoma in patients after discontinuation of antithrombotic therapy after interventional techniques.

\begin{tabular}{|c|c|c|c|c|}
\hline Study & $\begin{array}{l}\text { Antithrombotic/ } \\
\text { Anticoagulant }\end{array}$ & $\begin{array}{l}\text { Number of } \\
\text { Days Stopped } \\
\text { Prior to } \\
\text { Procedure }\end{array}$ & Case Report & Conclusion \\
\hline $\begin{array}{l}\text { Chiravuri et } \\
\text { al (187) }\end{array}$ & Clopidogrel & 10 days & $\begin{array}{l}\text { This is a case report in a } 49 \text {-year-old male for placement of } \\
\text { spinal cord stimulation trial leads for chest pain. Leads were } \\
\text { attempted to be placed at L1-L2 with Tuohy needle under live } \\
\text { fluoroscopic guidance contacting the L2 lamina with loss of } \\
\text { resistance technique to the air. Subarachnoid puncture was } \\
\text { noted with clear fluid flowing freely from the Tuohy needle. } \\
\text { The needle was withdrawn into the epidural space and a } \\
\text { spinal lead advanced to mid C7. Post operatively patient } \\
\text { reported a positional headache accompanied by nausea } \\
\text { and vomiting. This progressively worsened over the course } \\
\text { of the day, changing in character with loss of positional } \\
\text { component accompanied by emesis. His CT scan of the } \\
\text { head showed a large subdural hematoma. Neurosurgical } \\
\text { consultation was carried out and the patient underwent } \\
\text { emergency craniotomy. The remaining post-surgical } \\
\text { course was uneventful; however, on the postoperative day } 3 \\
\text { patient recalled falling at home one day prior to the spinal } \\
\text { cord stimulator implant, striking his head without loss of } \\
\text { consciousness. }\end{array}$ & $\begin{array}{l}\text { Even though this case presents } \\
\text { acute intracranial subdural } \\
\text { hematoma secondary to } \\
\text { unintentional dural puncture } \\
\text { during placement of permanent } \\
\text { spinal cord stimulator lead, it } \\
\text { also raises questions in reference } \\
\text { to the causal relationship of the } \\
\text { procedure and development } \\
\text { as there was history of a fall. } \\
\text { Even then, there is need for } \\
\text { careful follow-up of patients } \\
\text { with a known post dural tear. } \\
\text { Failure to identify uncommon } \\
\text { adverse events in patients } \\
\text { with complicated spinal cord } \\
\text { stimulator implantation may lead } \\
\text { to permanent injury. }\end{array}$ \\
\hline Xu et al (188) & $\begin{array}{l}\text { Warfarin, Aspirin, } \\
\text { Enoxaparin }\end{array}$ & $\begin{array}{l}6 \text { days and } 24 \\
\text { hours before } \\
\text { procedure }\end{array}$ & $\begin{array}{l}\text { Warfarin and aspirin stopped } 6 \text { days before the procedure } \\
\text { with bridging over to enoxaparin twice daily, with the last } \\
\text { enoxaparin dose at least } 24 \text { hours before the procedure. } \\
\text { A } 78 \text {-year old woman underwent lumbar interlaminar } \\
\text { epidural injection under fluoroscopic guidance. } 30 \text { hours } \\
\text { after the 3rd lumbar interlaminar epidural injection, the } \\
\text { following morning after the } 2 \text { nd shot of enoxaparin, the } \\
\text { patient developed excruciating radicular leg pain. CT } \\
\text { scan of the lumbar spine was inconclusive. Subsequently, } \\
\text { MR imaging of the lumbar spine showed a lumbar epidural } \\
\text { hematoma that spanned from L2 to L5 causing severe thecal } \\
\text { sac compression. She was treated with bilateral lumbar } \\
\text { laminectomies, foraminotomies and hematoma evacuation } \\
\text { from L2-L5. The patient had unremarkable postoperative } \\
\text { course. The epidural hematoma developed despite } \\
\text { cessation of all drugs within the guidelines and restarting of } \\
\text { enoxaparin within the guidelines. }\end{array}$ & $\begin{array}{l}\text { Despite strict adherence to } \\
\text { anticoagulation guidelines, } \\
\text { epidural hematoma developed. }\end{array}$ \\
\hline $\begin{array}{l}\text { Ain et al } \\
\text { (189) }\end{array}$ & $\begin{array}{l}\text { Warfarin, } \\
\text { Enoxaparin }\end{array}$ & $\begin{array}{l}\text { Warfarin was } \\
\text { stopped for } \\
6 \text { days and } \\
\text { Enoxaparin } \\
\text { was stopped } \\
\text { for over } 24 \\
\text { hours prior to } \\
\text { the injection. } \\
\text { INR was } 1.2\end{array}$ & $\begin{array}{l}\text { A patient with renal insufficiency received an epidural } \\
\text { injection at L3-L4 interspace. Enoxaparin regimen was } \\
\text { reinstituted } 24 \text { hours after the procedure. } 48 \text { hours after } \\
\text { the procedure she reported } 100 \text { times worse back pain } \\
\text { in the same location as before the epidural injection. } \\
\text { Magnetic resonance imaging study showed severe central } \\
\text { canal stenosis centered at L3-4 from a posterior epidural } \\
\text { hematoma. Epidural hematoma extended from L2 through } \\
\text { L4. Her anticoagulation regimen was discontinued } \\
\text { and managed conservatively. The second day the patient } \\
\text { experienced increased numbness and weakness in the } \\
\text { lower extremities. Subsequent MRI revealed increasing } \\
\text { size of the epidural hematoma extending from L1 to L5. } \\
\text { Decompression laminectomies were performed from L2 to } \\
\text { L4 and dexamethasone was given for } 3 \text { days. }\end{array}$ & $\begin{array}{l}\text { Patient developed epidural } \\
\text { hematoma after epidural injection } \\
\text { despite strict adherence to the } \\
\text { guidelines for neuraxial anesthesia } \\
\text { and anticoagulation regarding } \\
\text { administration of low molecular } \\
\text { weight heparin. }\end{array}$ \\
\hline $\begin{array}{l}\text { Reitman and } \\
\text { Watters (191) }\end{array}$ & Aspirin $(325 \mathrm{mg})$ & 7 days & $\begin{array}{l}\text { A 62-year-old woman underwent an uncomplicated cervical } \\
\text { epidural steroid injection. She developed acute onset of axial } \\
\text { pain followed by progressive quadriparesis within a matter } \\
\text { of } 8 \text { hours. Emergency CT scan suggested posterior cord } \\
\text { displacement consistent with an anterior spinal hematoma } \\
\text { from C3 through C5. She was taken to the operating room } \\
\text { and appropriate decompression was carried out showing } \\
\text { anterior subdural hematoma. Patient continued to be } \\
\text { quadriplegic, even though rapidly gained full function in } \\
\text { the left upper and lower extremities. She developed acute } \\
\text { meningitis and cardiac arrests and finally died. }\end{array}$ & $\begin{array}{l}\text { Epidural hematoma can occur } \\
\text { even after appropriate cessation } \\
\text { of aspirin. Despite rapid diagnosis } \\
\text { and surgical intervention, the } \\
\text { outcome was bad in this case. }\end{array}$ \\
\hline
\end{tabular}

NSAIDs = non-steroidal anti-inflammatory drugs; MRI = magnetic resonance imaging; INR - international normalized ratio; CT - computed tomography 


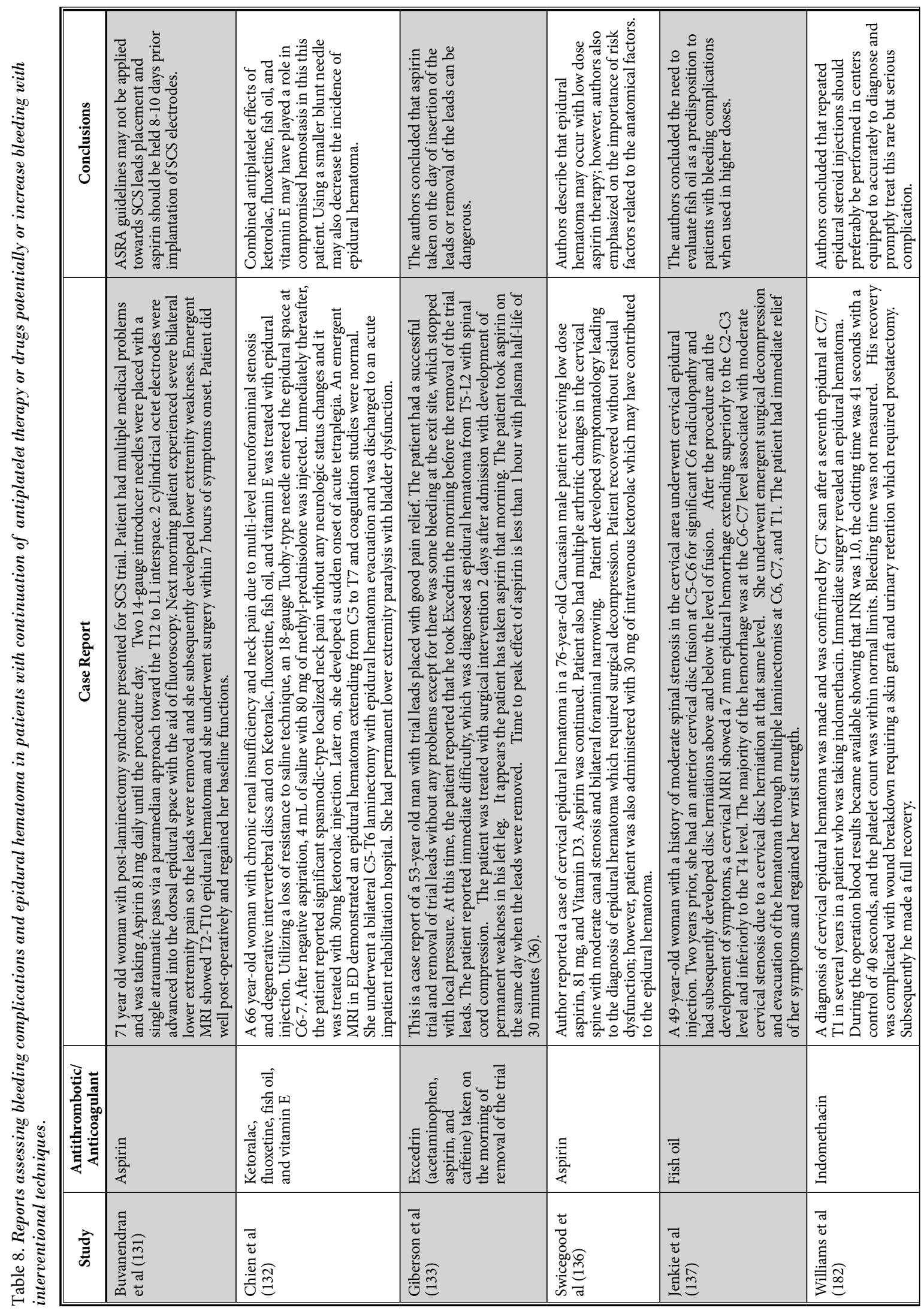

www.painphysicianjournal.com 


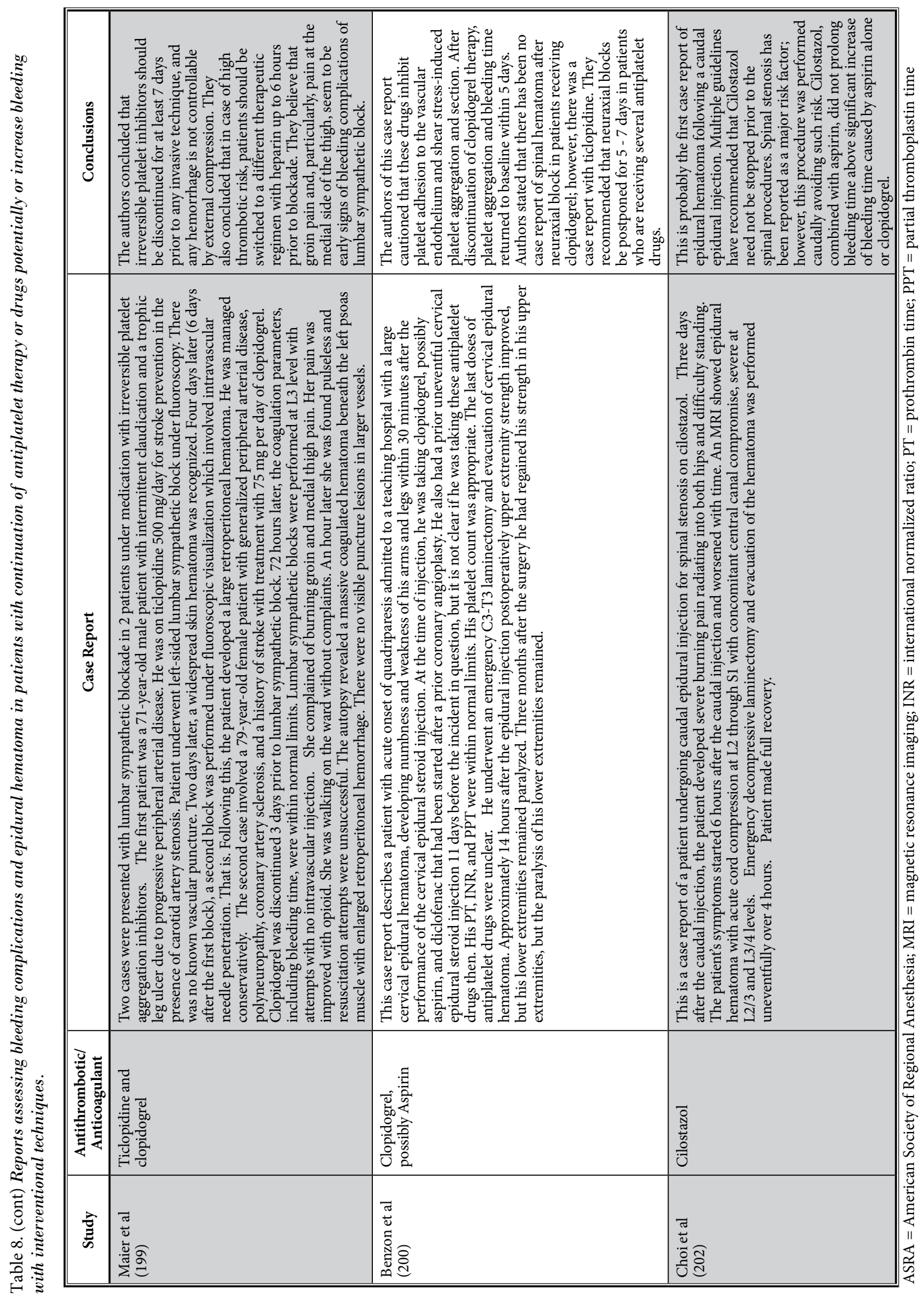


Table 9 shows summary reports of a number of epidural hematomas with epidural injections, acupuncture and dry needling, and spinal cord stimulation lead placement in patients without antithrombotic therapy, with antithrombotic therapy withheld for appropriate duration, and with antithrombotic therapy continued (Figs. 2-4). A total of 38 epidural hematomas were described in 35 case reports. There were 20 in cervical spine, 8 in thoracic spine, and 10 in lumbar spine. Of these, 19 patients were on no antiplatelet therapy, 11 patients had their antithrombotic therapy discontinued, and 8 continued antithrombotic therapy. Further, as shown in Fig. 4, epidural injections were responsible for 25 cases of hematomas, 7 cases were secondary to acupuncture or dry needling and 6 were related to spinal cord stimulation. There was one case report of caudal epidural injection with cilostazol (202), and in one case report we were unable to obtain full manuscript (207). Cases of chronic subdural hematoma and cases of abdominal hematomas were not included.

Table 9. Reports of epidural hematomas.

\begin{tabular}{|c|c|c|c|c|}
\hline & No Anticoagulant Therapy & Anticoagulant Discontinued & Anticoagulant Continued & Total \\
\hline $\begin{array}{l}\text { Cervical Epidural } \\
\text { Stimulator trial } \\
\text { Acupuncture/Dry Needling }\end{array}$ & $\begin{array}{l}8 \\
0 \\
3\end{array}$ & $\begin{array}{l}\text { Aspirin - } 2 \\
\text { Clopidogrel - } 1 \\
\text { Warfarin - } 1\end{array}$ & $\begin{array}{c}\text { Aspirin - 1 } \\
\text { Fish oil - } 2 \\
\text { Indomethacin - } 1 \\
\text { Clopidogrel - } 1 \\
\end{array}$ & \\
\hline TOTAL & 11 & 4 & 5 & 20 \\
\hline $\begin{array}{l}\text { Thoracic Epidural } \\
\text { Stimulator trial } \\
\text { Acupuncture/Dry Needling }\end{array}$ & $\begin{array}{l}0 \\
3 \\
1 \\
\end{array}$ & $\begin{array}{l}\text { Aspirin } 1 \\
\text { Aspirin } 1\end{array}$ & Aspirin 2 & \\
\hline TOTAL & 4 & 2 & 2 & 8 \\
\hline $\begin{array}{l}\text { Lumbar Epidural } \\
\text { Stimulator trial } \\
\text { Acupuncture/Dry Needling }\end{array}$ & $\begin{array}{l}1 \\
0 \\
3 \\
\end{array}$ & $\begin{array}{c}\text { Aspirin }+ \text { Clopidogrel }-1, \\
\text { Warfarin }-3 \\
\text { Dabigatran }-1 \\
\end{array}$ & Cilostazol (caudal) -- 1 & \\
\hline TOTAL & 4 & 5 & 1 & 10 \\
\hline COMBINED TOTALS & 19 & 11 & 8 & 38 \\
\hline
\end{tabular}
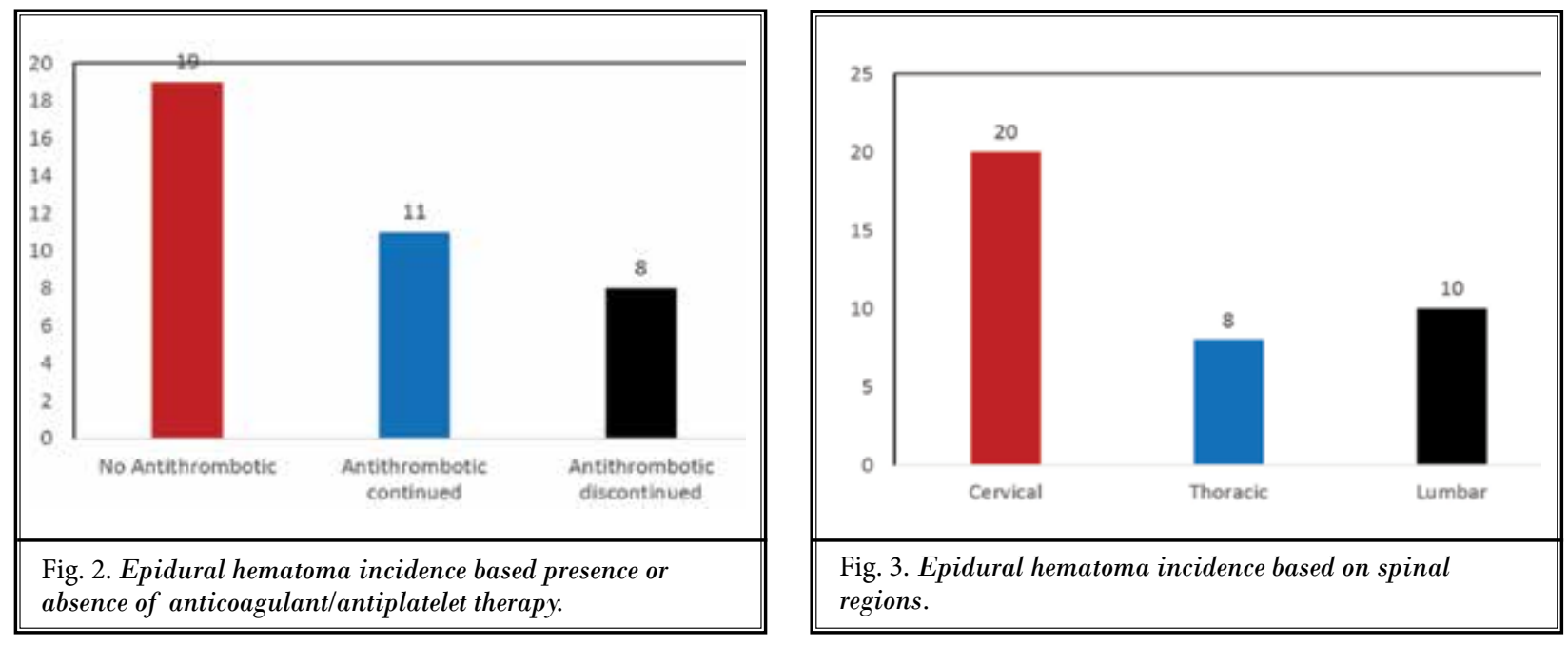


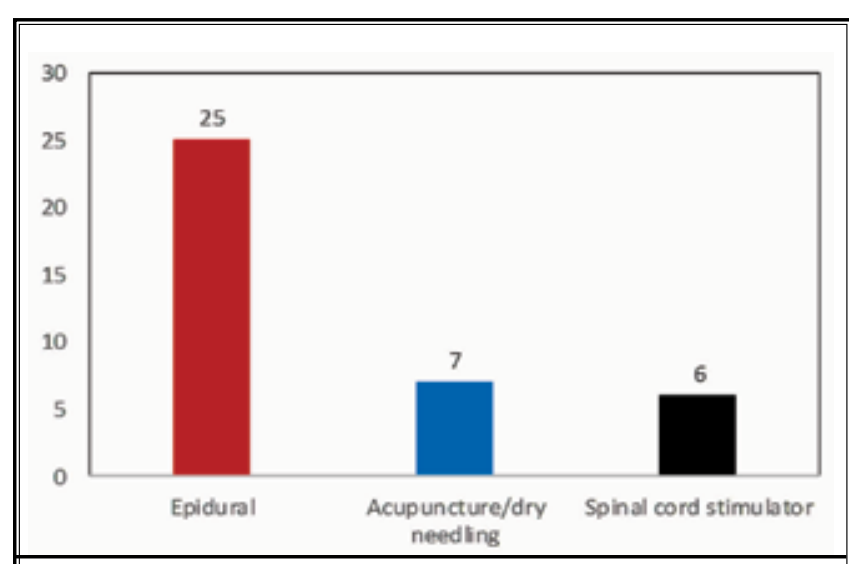

Fig. 4. Epidural hematoma cases reported based on type of procedure.

\subsection{Guidelines And Recommendations}

Guidelines and recommendations were based on risk stratification, pharmacology of antithrombotics and anticoagulants, and application of available evidence.

\subsection{Risk Stratification}

Interventional techniques performed in the spine and other regions for chronic cancer and noncancer pain patients face variable risks depending on anticoagulant or antithrombotic therapy, age, anatomy, the specific region of interest, and obesity. Consequently, various authors have described procedural classification according to the potential risk for serious bleeding.

Raj et al (212) stratified risk score based on technique related bleeding risk and patient-related bleeding risk factors. This risk classification took various factors into consideration including a sharp or blunt needle, use of fluoroscopy and lack of fluoroscopy.

Breivik et al (36) in a comprehensive topical review of reducing risk of spinal hematoma from spinal epidural and pain procedures based their recommendations on extensive review of 166 case reports published since 1994 through 2015 (52,53), pharmacology of drugs, and available clinical evidence relating to complications whether or not the antithrombotics were continued or discontinued.

Narouze et al (40) provided guidance for interventional spine and pain procedures in patients on antiplatelet and anticoagulant medications. They provided extensive review of the literature, considered pharmacology, and current literature with development of risk stratification.

Deer et al (39) provided recommendations on bleeding and coagulation management in neurostimulation devices. They also provided bleeding risk stratifications for neuromodulation procedures. Their classification showed spinal cord stimulation trial and implant, dorsal root ganglion stimulation, and intrathecal catheter and pump implant as high to intermediate risk neuromodulation procedures. Further, they classified deep brain stimulation and motor cord stimulation as high-risk neuromodulation procedures. This is in contrast to other guidance where spinal cord stimulation trial and implant, dorsal root ganglion stimulation, and intrathecal catheter and pump implant are considered as high risk.

Oprea et al (20) published risk stratification, perioperative, and periprocedural management of patients receiving anticoagulant therapy based on bleeding risk for each procedure, pharmacology, and evidence of risk of development of bleeding complications as well as thromboembolic risks.

Lagerkranser (52) and Lagerkranser and Lindquist (53) published extensive review of neuraxial blocks and spinal hematoma with review of 100 case reports published from 1994 to 2015 with demographics and risk factors, as well as diagnosis, treatment, and outcome. They concluded that the annual number of published cases of spinal hematoma after central neuraxial blocks increased during 1994 to 2015 compared to previous years. Case reports on elderly women accounted for this increase; however, they also emphasized that anti-hemostatic drugs, heparins in particular, still continue to be major risk factors for developing post central neuraxial blockade spinal bleedings. They also described other risk factors related to hemostasis and spinal disorders and complicated blocks, especially spinal stenosis and "bloody taps," whereas multiple attempts do not seem to increase the risk of bleeding (Table 10). Further, they conceded that in a large number of cases, no risk factor was reported.

Lagerkranser (52) also identified patient-related risk factors as shown in Table 10. Topping the list of the risk factors is spinal disease in general and spinal stenosis in particular. Surprisingly, INR of $\geq 1.5$ was the least related risk factor second only to liver disease.

Among the drug-related risk factors, these were the most common risk factors with the intake of antihemostatic drugs in 105 of 166 cases (63\%), and with no drug therapy in $37 \%$ of cases. Further, in 47 of the cases, more than one anti-hemostatic drug was implicated in 12 cases in 3 such drugs. Table 11 shows drug related risk factors with low molecular heparin topping with $31 \%$ of the cases, aspirin at third level 
with $16 \%$ of cases, vitamin $\mathrm{K}$ antagonist with $11 \%$ of the cases, NSAIDs also at $11 \%$, and adenosine diphosphate (ADP)-receptor inhibitors and phosphodiesterase inhibitors at $2.5 \%$ and $1.3 \%$ respectively.

They also concluded that guidelines issued around the turn of the century do not seem to have affected the number of published reports. They also concluded that the complications continue to occur despite following the appropriate guidelines and strict adherence to the recommendations. Consequently, they concluded that there are no guarantees against such bleedings to occur, even if guidelines are strictly followed.

Lagerkranser (52) and Lagerkranser and Lindquist (53) also concluded that suspicion of a spinal hematoma calls for the consultation of an orthopedic or neurological surgeon without delay. Surgical evacuation within 12 hours from the first sign of motor dysfunction seems to lead to the best outcome, even though many patients operated on later than 24 hours did regain full motor function. They also concluded that despite the poor prognosis after surgical evacuation of spinal hematoma, the outcomes after central neural blockade in general have improved significantly over time.

Our data analysis in this report showed interlaminar epidural injections, spinal cord trial lead placement through interlaminar approach, and spinal stenosis as risk factors. Overall, as shown in Fig. 2, when antithrombotics were continued, epidural hematomas occurred in 8 patients compared to 19 with no antithrombotic therapy and 11 with antithrombotic therapy appropriately discontinued. This provides a ratio of $27 \%$ incidence of hematomas when antithrombotics were continued compared to $73 \%$ with either no antithrombotics, or with appropriate discontinuation of antithrombotics. There were larger number of patients in the group where antithrombotics were discontinued with 11 compared to 8 in continued group. The majority of the hematomas were reported in the cervical region with 20, followed by 10 in the lumbar region and 8 in thoracic region (Fig. 3). Further analysis also showed that 25 of 38 cases were related to epidural injections, 7 were related to either acupuncture or dry needling, and 6 were related to spinal cord stimulation (Fig. 4). Thus, epidural injection, specifically in the cervical spine, is considered as high risk, along with spinal cord lead placement. This is illustrated in Figs. 5 to 7. As shown in Fig. 5, cervical epidural hematoma incidence was highest in patients without any antithrombotic therapy with 11 patients, followed by continuation of antithrombotic therapy in 5 patients, followed by in 4 patients where antithrom-
Table 10. Patient related risk factors as described in review of 166 cases of spinal hematoma.

\begin{tabular}{||l|c||}
\hline \multicolumn{1}{|c|}{ Disorder } & No. of cases \\
\hline Spinal stenosis & 14 \\
\hline Spinal tumor & 6 \\
\hline Ankylosing spondylitis & 4 \\
\hline Osteoporosis & 4 \\
\hline Herniated disc & 2 \\
\hline Scoliosis & 2 \\
\hline Spondylosis & 2 \\
\hline Spina bifida occulta & 1 \\
\hline Dural AV-fistula & 1 \\
\hline Spinal AVM & 1 \\
\hline Spinal disease (total) & 37 \\
\hline Thrombocytopenia & \\
\hline Renal insufficiency & $13^{\mathrm{b}}$ \\
\hline INR $\geq 1.5$ & 10 \\
\hline Liver disease & $6^{\mathrm{c}}$ \\
\hline \hline
\end{tabular}

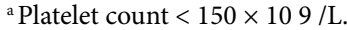

${ }^{\mathrm{b}}$ Including 2 obstetric cases, one with HELLP (haemolysis, elevated liver enzymes, and low platelets), and one with eclampsia, and one patient with idiopathic thrombocytopenic purpura, discovered postlaminectomy.

${ }^{\mathrm{c}}$ In one case without anti-vitamin $\mathrm{K}$ treatment.

Source: Lagerkranser M. Neuraxial blocks and spinal haematoma: Review of 166 case reports published 1994-2015. Part 1: Demographics and risk-factors. Scand J Pain 2017; 15:118-129 (52).

Table 11. Drug classes reported, in order of frequency in 160 cases of spinal hematoma.

\begin{tabular}{|l|c|}
\hline & $\begin{array}{c}\text { No. of cases } \\
\text { (percentage) }\end{array}$ \\
\hline Low molecular weight heparin & $50(31)$ \\
\hline Unfractionated heparin & $39(24)$ \\
\hline Acetylsalicylic acid & $25(16)$ \\
\hline Vitamin-K antagonists & $17(11)$ \\
\hline Non-steroidal anti-inflammatory drugs & $17(11)$ \\
\hline Dextran & $6(3.8)$ \\
\hline Fibrinolytics & $4(2.5)$ \\
\hline ADP receptor inhibitors & $4(2.5)$ \\
\hline Phosphodiesterase inhibitor (dipyridamole) & $2(1.3)$ \\
\hline Direct fXa inhibitor (rivaroxaban) & $2(1.3)$ \\
\hline Direct thrombin inhibitor (dabigatran) & $1(0.6)$ \\
\hline Fondaparinux & $1(0.6)$ \\
\hline Selective serotonin receptor inhibitor & $1(0.6)$ \\
\hline \hline
\end{tabular}

Source: Lagerkranser M. Neuraxial blocks and spinal haematoma: Review of 166 case reports published 1994-2015. Part 1: Demographics and risk-factors. Scand J Pain 2017; 15:118-129 (52). 


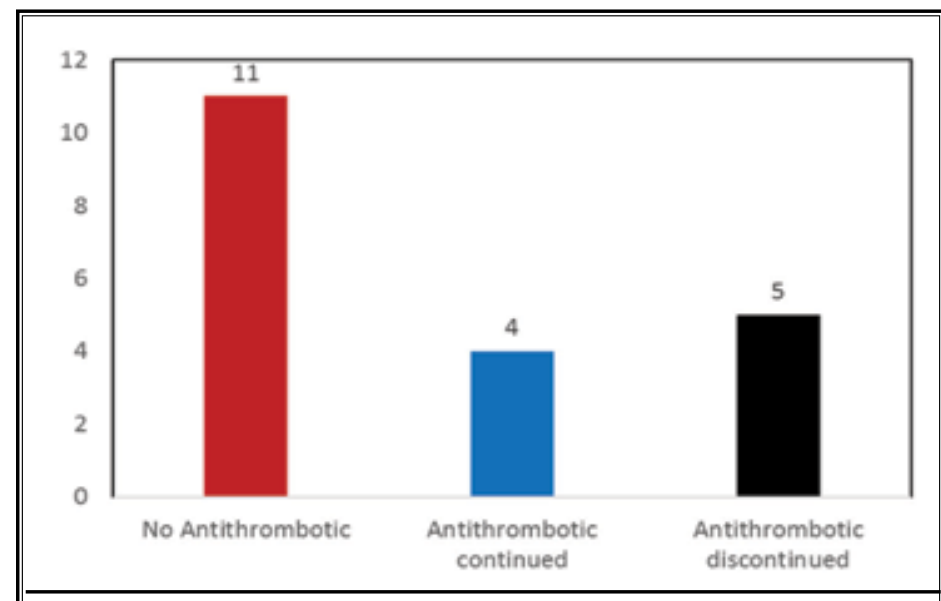

Fig. 5. Cervical epidural hematoma incidence bbased presence or absence of anticoagulant/antiplatelet therapy.

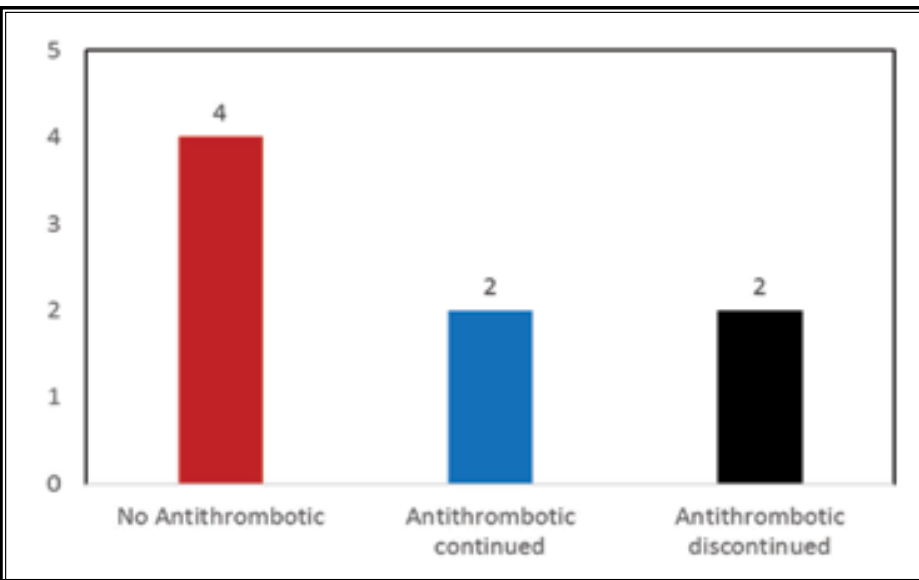

Fig. 6. Thoracic epidural hematoma incidence based presence or absence of anticoagulant/antiplatelet therapy.

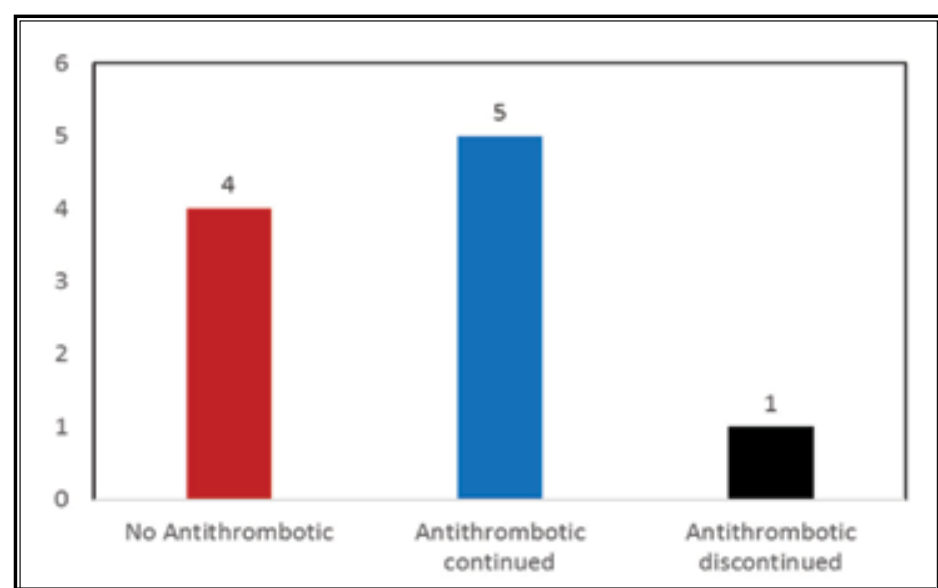

Fig. 7. Lumbar epidural hematoma incidence based presence or absence of anticoagulant/antiplatelet therapy. botic therapy was discontinued. Overall, in the cervical spine, in $67 \%$ of the patients developing hematoma formation, there were either no antithrombotics or antithrombotics were discontinued appropriately. Results were even more striking in lumbar spine as shown in Fig. 7. Overall, there were 10 instances of lumbar epidural hematoma, 4 in patients without antithrombotic therapy, 5 with appropriate discontinuation and only one patient where it was continued with cilostazol which is rarely utilized and none of the guidelines recommend it to be discontinued. Thus, in the lumbar spine, only one patient or $10 \%$ of epidural hematomas were related to continuation of antithrombotic therapy. In contrast, in the thoracic spine the results were similar to the cervical spine with 6 patients developing hematoma, either without anticoagulant therapy or after appropriate discontinuation $(4+2)$ and in 2 patients with continuation of antithrombotic therapy with a $25 \%$ incidence of epidural hematoma in the thoracic spine in patients continuing antithrombotic therapy similar to cervical spine and higher than lumbar spine.

The previous studies have shown low molecular weight heparin as the most frequently used drug followed by unfractionated heparin, followed by aspirin (Table 12). The present assessment showed aspirin as the most common drug with a total of 7 of 38 patients; however, it was continued only in 3 patients; whereas it was discontinued in 4 patients. Warfarin was also common with or without enoxaparin; however, it was discontinued according to the guidelines. Clopidogrel was reported in 3 cases with discontinuation in 2 patients and continuation in one patient. Many of the commonly utilized antithrombotics have not been identified in the present analysis.

Multiple factors and the available literature in reference to the adverse consequences of anticoagulant and antithrombotic therapy with interventional techniques were utilized in developing risk stratification. The following classification for interventional techniques has been developed (Table 13) $(1,20,31-40,52,53,198-200,212)$. The classification describes low risk, intermediate risk, and 
high-risk procedures. However, based on comorbid medical conditions and other risk factors of coagulopathies and concurrent use of other anticoagulants and antiplatelets, the procedural risk classification may be changed from low risk to intermediate, intermediate to high risk.

Of all the low risk procedures as shown in Table 13, caudal epidural injection was the only one which has reported an epidural hematoma with continuation of cilostazol (202). This is extremely unusual and probably coincidental. Consequently, with caudal epidural injections and other low risk procedures, antithrombotic and anticoagulant therapy may be continued with the appropriate guidelines.

Intermediate risk procedures include multiple procedures performed, constituting a great proportion of procedural prevalence. This risk stratification is somewhat different from the one proposed by ASRA (40). Justifiably we have included caudal percutaneous adhesiolysis into intermediate risk procedures as there have not been any case reports. Further, lumbar transforaminal epidural injections at L4, L5, S1, and sympathetic blocks have been included in these categories due to one or 2 case reports. Lumbar interlaminar epidural injections performed between L5 and $\mathrm{S} 1$ are included in intermediate risk procedures; whereas, procedures performed at L4-5 and at higher levels are included in high risk procedures. A majority of the lumbar epidural hematomas developed despite discontinuation of antithrombotic therapy and these were performed above L5-S1 interspace. If epidural hematoma develops at L5-S1 it will have significantly higher space availability to be asymptomatic and to be managed conservatively.

The high risk procedures include the majority of the procedures performed in the cervical and thoracic spine. These guidelines are in contrast to ASRA guidelines with the inclusion of cervical, thoracic, and high lumbar above L5-S1 due to the available literature and potential issues related to epidural hematoma requiring surgical exploration and spinal cord damage.

Table 12. Drug classes reported in order of frequency.

\begin{tabular}{|l|c|c|c|}
\hline & Continued & Discontinued & Total \\
\hline None & & & 19 \\
\hline Aspirin discontinued & 4 & 3 & 7 \\
\hline Warfarin discontinued & 0 & 4 & 4 \\
\hline Clopidogrel & 1 & 2 & 3 \\
\hline Fish oil & 2 & 0 & 2 \\
\hline Indomethacin & 1 & 0 & 1 \\
\hline Cilostazol & 1 & 0 & 1 \\
\hline Dabigatran & 0 & 1 & 1 \\
\hline
\end{tabular}

Table 13. Classification of interventional techniques based on the potential risk for bleeding.

\begin{tabular}{|c|c|c|}
\hline Low-Risk Procedures & Intermediate-Risk Procedures* & High-Risk Procedures* \\
\hline $\begin{array}{l}\text { 1. Trigger point and muscular } \\
\text { injections (including } \\
\text { piriformis injection) } \\
\text { 2. Peripheral joints } \\
\text { 3. Peripheral nerve blocks } \\
\text { 4. Sacroiliac joint and ligament } \\
\text { injections and nerve blocks } \\
\text { 5. Caudal epidural injections } \\
\text { 6. Ganglion impar blocks }\end{array}$ & $\begin{array}{l}\text { 1. Facet joint interventions (intraarticular injections, } \\
\text { nerve blocks and radiofrequency neurotomy) } \\
\text { 2. Lumbar transforaminal epidural injections at L4, } \\
\text { L5, S1 } \\
\text { 3. Lumbar intradiscal procedures } \\
\text { 4. Hypogastric plexus blocks } \\
\text { 5. Lumbar sympathetic blocks } \\
\text { 6. Peripheral nerve stimulation trial and implant } \\
\text { 7. Pocket revision and implantable pulse regenerator/ } \\
\text { intrathecal pump replacement } \\
\text { 8. Caudal percutaneous adhesiolysis } \\
\text { 9. Lumbar percutaneous disc decompression (L4/5 } \\
\text { or below) } \\
\text { 10. Lumbar vertebral augmentation (below L4) } \\
\text { 11. Intervertebral spinous prosthesis } \\
\text { 12. Lumbar discography } \\
\text { 13. Lumbar interlaminar epidural injections at L5-S1 }\end{array}$ & $\begin{array}{l}\text { 1. Cervical, thoracic, and high lumbar (above L4-L5) } \\
\text { interlaminar epidurals } \\
\text { 2. Cervical, thoracic and lumbar above L3 } \\
\text { transforaminal epidural injections } \\
\text { 3. Spinal cord stimulator trial and implant } \\
\text { 4. Percutaneous adhesiolysis with interlaminar or } \\
\text { transforaminal approach } \\
\text { 5. Percutaneous disc decompression (above L4/5) } \\
\text { 6. Sympathetic blocks (stellate ganglion; thoracic } \\
\text { splanchnic, celiac plexus) } \\
\text { 7. Thoracic and cervical intradiscal procedures } \\
\text { 8. Vertebral augmentation, lumbar (above L4), } \\
\text { thoracic and cervical } \\
\text { 9. Intrathecal catheter and pump implant } \\
\text { 10. Interspinous prosthesis and MILD }\end{array}$ \\
\hline
\end{tabular}

${ }^{\star}$ Patients with high risk of bleeding (e.g., old age, history of bleeding tendency, concurrent uses of other anticoagulants/antiplatelets, liver cirrhosis or advanced liver disease, and advanced renal disease) undergoing low or intermediate-risk procedures should be treated as intermediate or high risk, respectively. 


\subsection{Pharmacologic Aspects and Hemostasis Monitoring}

The main categories of antithrombotics and anticoagulants are described as; platelet inhibitors, interfering with platelet aggregation (clumping) and thrombus formation; anticoagulants interfering with formation of the clotting, thereby reducing fibrin formation and preventing clots from forming and expanding; and fibrinolytics interfering with the final clot.

Monitoring of hemostasis is performed with multiple standard tests including platelet count, activated partial thromboplastin time (APTTa), and INR. The normal platelet count is $x 109 \mathrm{~L}-1$ from 150 to 350 with recommended counts of greater than 50 for vital lifethreatening indication, greater than $\mathbf{8 0}$ for strong indication, and greater than 100 for weak indication (36). A normal INR is considered as 0.9 to 1.2. Consequently, for epidural injections, INR of less than 1.5 is ideal for high risk and moderate risk procedures, and less than 1.8-2.00 is ideal for low risk procedures.

Additional advanced hemostatic tests for monitoring of hemostasis include multiple viscoelastic tests like thromboelastography or thromboelastrometry extensively used to evaluate liver disease (213). However, this parameter has been studied for safe epidural catheter removal with the conclusion that the tests were not well validated in this context and there were frequent false negative test results $(214,215)$. Even then, a clearly abnormal curve indicates deranged hemostasis and must be taken seriously $(215,216)$.

\subsubsection{NSAIDS and Aspirin}

NSAIDs inhibit cyclooxygenase enzymes COX1 and COX2, which inhibit prostaglandin production to decrease the inflammatory response. Thus, NSAIDs have analgesic effects and are used for minimizing pain. Thromboxane $A 2$ is produced via COX1 enzyme activity, which is a potent thrombus activator. Aspirin is an irreversible inhibitor of COX1 and has significant clinical benefits for preventing thrombus formation. In response to aspirin, more prostacyclin is produced by endothelial cells, but there is no additional thromboxane made as there are no nuclei in platelets, thus, there is a greater percent of prostacyclin to thromboxane, thinning the blood. Elevated bleeding risk is a concern for a small portion of patients, but adverse effects are rare. Prostacyclin (PGI2) synthesis from vascular endothelial cells is dependent on COX2 and has anti-platelet effects. High doses of aspirin reduce $\mathrm{PGI} 2$ production which can abolish the anti-platelet effect of low dose aspirin.
Low-dose aspirin anti-platelet effects last for 7-10 days, as bone marrow directed platelet renewal is required for clotting to resume. Low-dose aspirin therapy is well established to reduce the risk of cardiovascular events in patients with acute coronary syndromes, cerebral infarct, or occlusive vascular disease (217). However, recently published large scale evidence (15-19) shows lack of benefit with aspirin for primary prevention of cardiovascular events, while it does increasethe risk of bleeding.

The data reported by Lagerkranser et al (52) and the data derived from the present analysis are shown in Tables 11 and 12. Aspirin was the most common drug of the 19 cases of epidural hematoma reported in this series with 7 with use of aspirin. Four patients discontinued aspirin appropriately and 3 patients continued. In the data by Lagerkranser et al (52), aspirin was utilized in $16 \%$ of patients reporting spinal hematoma of 160 cases constituting a total of $18 \%$ in the present series. Eight percent continued aspirin and $11 \%$ discontinued aspirin. The most common drug reported in Lagerkranser et al (52) series was low molecular weight heparin in $31 \%$ of the cases and Warfarin in $11 \%$ of the cases. In the present series, Warfarin with or without low molecular weight heparin was utilized in 4 patients with $11 \%$ utilization.

Table 14 shows pharmacokinetic and pharmacodynamic characteristics of aspirin and NSAIDs. Time to $50 \%$ recovery of platelet function with aspirin is shown as 3 days (36). Antiplatelet function of irreversible inhibitors is dependent mainly on platelet regeneration than drug half-life. While bleeding complications have been reported without any drug therapy, majority of the bleeding complications were related to aspirin in $18 \%$ while $11 \%$ discontinued and $7 \%$ continued.

For other NSAIDs, unlike aspirin, the platelet effects of these drugs are directly related to systemic plasma drug concentrations and influenced by the pharmacokinetic clearance of these medications. It takes approximately 5 half-lives for systematic elimination. Recent recommendations (40) have revised recommendations for aspirin, whether to continue or discontinue in the perioperative period for interventional pain procedures. Decision-making is based on the reason for aspirin utilization, a multitude of risk factors including vascular anatomy surrounding the target area, degree of the invasiveness of the procedure, and potential sequelae associated with perioperative bleeding. Thus, aspirin for primary prophylaxis can be stopped without any hesitation. The major consideration in withholding 
Table 14. Characteristics of aspirin and NSAIDs.

\begin{tabular}{|l|c|c|}
\hline & $\begin{array}{c}\text { Aspirin or acetylsalicylic acid (Oral } \\
\text { Low Dose) }\end{array}$ & NSAIDs \\
\hline Target & COX -1 irreversible & COX-1 reversible, COX-2 \\
\hline Time to peak effect & 0.5 hours & Varies \\
\hline Plasma Half Life & 0.5 hours & + \\
\hline Renal elimination & + & 1 day \\
\hline Time to 50\% recovery of platelet function & 3 days & Heble from 1 to 72 hours \\
\hline Hours to C-Max & 0.5 hours & Hepatic \\
\hline Metabolism & Hepatic & $50-95 \%$ \\
\hline Bioavailability & $60 \%$ & + \\
\hline Antihemostatic effect & ++ & + \\
\hline
\end{tabular}

NSAID = non-steroidal anti-inflammatory drug; COX = cyclo-oxygenase

Rating of antihemostatic effect and renal elimination: $(+)=$ insignificant; $+=$ low; $++=$ moderate; $+++=$ pronounced; $++++=$ high

aspirin is the thromboembolic risk. Based on the available evidence, it appears that aspirin discontinuation for 4 days may be sufficient. In contrast, for non-steroid anti-inflammatory agents, recommended discontinuation by ASRA is one day for diclofenac, ibuprofen, and Ketoralac. Recommended discontinuation time is 2 days for etodolac and indomethacin. Discontinuation is about 4 days for meloxicam and Naprosyn, 6 days for nabumetone, and 10 days for piroxicam and oxaprozin. However, the evidence for stopping non-steroidal anti-inflammatory agents other than aspirin seems to be very limited. Stopping these drugs may become a practical issue and patients may not like it to stop all the drugs and complain of significantly more pain. Consequently, based on available, very limited, evidence, the clinician may continue or discontinue.

\subsubsection{ADP Receptor Inhibitors}

ADP-receptor inhibitors inhibit platelet aggregation. The drugs in this category utilized for clinical applications include Clopidogrel (Plavix®), Prasugrel (Effient $\circledast$ ), Ticlopidine (Ticlid $®$ ), and Ticagrelor (Brilinta $®$ ). Table 15 shows comparative pharmacokinetics and pharmacodynamics of ADP-receptor inhibitors.

Clopidogrel is the prototypical thienopyridine drug that inhibits the P2Y12 receptor. The P2Y12 receptor is activated by ADP binding and promotes platelet aggregation. Depending on the dosage schedule, the maximal platelet aggregation inhibitory effects of clopidogrel are reached within 3 to 7 days. After discontinuation, recovery of platelet inhibition occurs $50 \%$ after 3 days and full recovery after one week (218) Eighty percent of subjects demonstrated normal platelet aggregation by the 4 th day (218). Other studies have demonstrated the recovery of platelet function after cessation of aspirin in volunteers in surgical patients after 3 days in volunteers and within 4-6 days in surgical patients (211). In this study, by day 6 , all of the subjects had restored platelet aggregation to at least $85 \%$ of the baseline level.

Ticlopidine also belongs to the thienopyridine group and is maximally aggregated after 8 to 11 days of a $500 \mathrm{mg}$ per day dosage schedule. After withdrawal of 72 hours, there is still a lingering effect as there is an irreversible inhibition of platelet function (219). Prasugrel acts by antagonizing ADP at the platelet's purine receptors, and aggregation is thus noncompetitively and irreversibly inhibited.

Prasugrel, or Effient, has significantly higher irreversible antiplatelet activity compared to clopidogrel with time to peak effect of one hour. Thus, administration of first dose results in around half of the platelets being inhibited within the first hour of taking this medication. Following three to five days of therapy, the steady-state inhibition of platelet aggregation reaches around $70 \%$ (220). As a prodrug, prasugrel is rapidly metabolized to active and inactive metabolites. These metabolites have varying elimination rates, although the active metabolites have an elimination half-life of 7 hours, with a wide range of 2-15 hours (221).

Lastly, a distinct ADP-receptor inhibitor is Ticagrelor, which directly inhibits $\mathrm{P} 2 \mathrm{Y} 12$ receptors (222-224). While Ticagrelor is metabolized to active metabolites, the original compound is responsible for the majority of the inhibitory effects $(223,224)$. A notable advantage of Ticagrelor is rapid effect, with peak platelet inhibition after 2 to 4 hours of intake (225). These medications undergo hepatic conversion to active metabolites, which are then eliminated by the kidneys (226). In addition, glycoprotein 
Pain Physician: Guidelines Issue 2019; 22:S75-S128

Table 15. Comparative pharmacokinetics/pharmacodynamics of ADP-receptor inhibitors.

\begin{tabular}{|c|c|c|c|c|}
\hline & - Clopidogrel (Plavix ${ }^{\circledR}$ ) & Prasugrel $\left(\right.$ Effient $\left.^{\circledR}\right)$ & Ticlopidine $\left(\right.$ Ticlid $^{\circledR}$ ) & ${\text { Ticagrelor }\left(\text { Brilinta }^{\circledR} \text { ) }\right.}$ \\
\hline Target & P2Y12ADP & P2Y12ADP & $\begin{array}{l}\text { P2Y12ADP, also inhibits } \\
\text { liver CYP2C19 and } \\
\text { CYP2B6 }\end{array}$ & P2Y12ADP \\
\hline $\begin{array}{l}\text { Antithrombotic } \\
\text { activity }\end{array}$ & ++ & +++ & ++ & ++++ \\
\hline Time to Cmax & 3-7 days & 3-5 days & 8-11 days & 2-4 hours \\
\hline Time to peak effect & 4 hours to 4 days & 1 hour & 3-5 days & 2.5 hours \\
\hline CYP metabolism & $\begin{array}{l}\text { CYP1A2, CYP2B6, } \\
\text { CYP2C } 9, \text { CYP2C19 and } \\
\text { CYP3A } 4 / 5\end{array}$ & $\begin{array}{l}\text { CYP450-mediated } \\
\text { (primarily CYP3A4 and } \\
\text { CYP2B6) }\end{array}$ & Cytochromes P450 & CYP3A4 \\
\hline Bioavailability & $>50 \%$ & $\geq 79 \%$ & $>80 \%$ & $36 \%$ \\
\hline Protein binding & $94-98 \%$ & Active metabolite: $98 \%$ & $98 \%$ & $>99.7 \%$ \\
\hline Plasma half-life & $\begin{array}{l}\text { 7-8 hours (inactive } \\
\text { metabolite) }\end{array}$ & $\begin{array}{l}\sim 7 \text { hours (range } 2 \text { hours to } \\
15 \text { hours) }\end{array}$ & $\begin{array}{l}12 \text { hours (single dose) } 4-5 \\
\text { days (repeated dose) }\end{array}$ & $\begin{array}{l}7 \text { hours (ticagrelor), } 8.5 \\
\text { hours (active metabolite } \\
\text { AR-C124910XX) }\end{array}$ \\
\hline Renal elimination & $50 \%$ kidney, $46 \%$ biliary & $\begin{array}{l}\text { Urine ( } 68 \% \text { inactive } \\
\text { metabolites); feces }(27 \% \\
\text { inactive metabolites) }\end{array}$ & Renal and fecal & Biliary \\
\hline $\begin{array}{l}\text { Time to } 50 \% \text { recovery } \\
\text { of platelet function }\end{array}$ & 3 days & 3 days & 6 days & 1.5 days \\
\hline
\end{tabular}

CYP = cytochrome P450

IIB/IIIA receptors are less activated, causing a reduction in fibrinogen fixation and platelet crosslinking.

ADP inhibitors were described as responsible for the formation of epidural hematoma after central neuraxial blockade in $2.5 \%$ of 160 cases or 4 cases. In the present assessment, clopidogrel either in combination with aspirin or ticlopidine was utilized in a total of 3 cases, with 2 cases being discontinued appropriately and one case it was continued. Thus, ADP inhibitors with reports available for only one or 2 drugs showed any relevance in $8 \%$ of the cases with only one case or $2.6 \%$ of cases where it was continued and in $5 \%$ of the cases it was discontinued. This is similar to the reports from Lagerkranser et al (52).

\subsubsection{Phosphodiesterase (PDE) Inhibitors}

Phosphodiesterase inhibitors include Cilostazol (Pletal $®$ ) and Dipyridamole (Persantine $®$ ). These medications selectively inhibit phosphodiesterase, which leads to an increase in intracellular cyclic adenosine monophosphate (CAMP) and subsequent reversible inhibition of platelet aggregation (227). Additionally, Dipyridamole blocks thromboxane synthase, the thromboxane receptor, and the cellular reuptake of adenosine into platelets, red blood cells, and endothelial cells. This results in increased adenosine in the extracellular space and inhibition of formation of cytokines and proliferation of smooth muscle cells. Absorption of Dipyridamole occurs in the gastrointestinal tract and is $\mathrm{pH}$ dependent. Gastric acid suppressors and proton pump inhibitors inhibit absorption, which can be prevented via buffered additives added to the medication (228). An additional advantage of Cilostazol is inhibition of PDE3A, which is selective to vascular smooth muscle cells and results in vasodilatation. Cilostazol is administered at $100 \mathrm{mg}$ twice daily and reaches maximum plasma levels after three hours. It is eliminated via hepatic metabolism and is excreted in the urine (229). Thus, cilostazol is contraindicated in those with severe renal insufficiency. For interventional procedures, phosphodiesterase inhibitors have been considered as safe to continue. However, risk may increase with addition of aspirin. Limited data exists evaluating the risk of perioperative surgical bleeding with cilostazol (40) and no standard perioperative guidelines are available (230). Further, if the medication is discontinued, at 50 hours (approximately 5 half-lives), less than $5 \%$ of the drug remains in plasma and improvements in platelet aggregation have been demonstrated, despite continuous prior dosing $(210,231)$.

There is a single case report of bleeding complications associated with interventional technique (202). In this case report, the patient underwent a caudal epidural injection developing epidural hematoma 
extending from L2 through S1 with concomitant central canal compromise, severe at L2-3 and L3-4 levels. This patient received, in the past, lumbar interlaminar epidural injection without any side effects. Emergency decompression laminectomy was carried out with the patient making full recovery. This is the only case report in interventional techniques. Cilostazol alone without aspirin is recommended to be continued during interventional techniques. Lagerkranser et al (52) also reported 2 cases of phosphatase inhibitors with dipyridamole with an incidence of $1.3 \%$ in 160 cases. Overall cilostazol is considered as a low risk drug and its continuation is appropriate.

\subsubsection{Glycoprotein GPIIb/IIIa Inhibitors}

A final common component of platelet aggregation is the glycoprotein Ilb/llla receptor. Specialized medications inhibit this receptor, potently inhibiting platelet aggregation while being reversible (172).

Abciximab (ReoPro ${ }^{\circledR}$ ) is a Fab fragment of a humanized monoclonal antibody directed against the GFPIlb receptor. Abciximab inhibits over $80 \%$ of ADPinduced platelet aggregation and is given via IV administration. Additionally, thrombin generation is inhibited by Abciximab, which quickly binds to platelets with high affinity.

Eptifibatide (Integrilin $®$ ) is a cyclic peptide inhibitor of the fibrinogen binding site on the GPIIb receptor. Tirofiban (Aggrastat@) is an additional glycoprotein Ilb/ Illa receptor inhibitor, reaching maximum efficacy after 4 hours of administration, with $50-80 \%$ inhibition of platelet aggregation (232). Platelet function normalizes 8 to $24 \mathrm{~h}$ after stopping the IV infusion.

There were no case reports secondary to development of epidural hematoma in patients receiving glycoprotein IIB/IIIA. In addition, it appears that these drugs are not commonly used for prevention of thromboembolic activity.

\subsubsection{Low-Molecular Weight Heparin}

Low molecular weight heparins (LMWHs) inhibit the coagulation cascade via binding to antithrombin, which leads to a conformational change of antithrombin, which accelerates inhibition of factor $\mathrm{Xa}$. LMWH has advantages: relatively high bioavailability, longer half-life, and ability for use once per day. Maximum efficacy levels are observed after 3-4 hours post subcutaneous administration, and elimination occurs after 4-6 hours in those with normal renal function (233). High molecular weight heparins $(\mathrm{HMWH})$ catalyze the inhibition of clotting factors IXa, Xa and thrombin by greatly enhancing antithrombin III activity, by causing a conformational change in ATIII exposing its reactive site. Testing is required to determine the dose effect on coagulation via partial thromboplastin time (PTT). $\mathrm{HMWH}$ is not absorbed by $\mathrm{Gl}$ tract due to its large molecular weight, therefore IV or SC injection must be used. The short half-life of HMWH approximately 1h) means frequent injections or continuous infusion, and it is thus not considered suitable in an outpatient setting.

Low molecular weight heparin is one of the commonly used drugs and has been implicated in multiple cases of epidural hematoma. Lagerkranser et al (52) showed low molecular weight heparin being responsible for the highest number of cases in $31 \%$ of the reports. Our reports also show 2 cases of warfarin with bridging with LMWH being responsible for epidural hematoma $(188,189)$, both in the lumbar spine.

\subsubsection{Warfarin}

Oral anticoagulants inhibit the synthesis of vitamin K-dependent clotting factors, which are factor II, VII, $\mathrm{IX}$, and $\mathrm{X}$. Warfarin blocks the gamma-carboxylation of glutamate residues in prothrombin and factors VII, $\mathrm{IX}$, and $\mathrm{X}$. This results in biologically inactive coagulation factor molecules. Vitamin $\mathrm{K}$ epoxide reductase is the enzyme that catalyzes the carboxylation reaction. Therapeutic doses of warfarin inhibit vitamin $\mathrm{K}$ epoxide reductase, which prevents the reductive metabolism of the inactive vitamin $\mathrm{K}$ epoxide to its active hydroquinone form. Synthesis is the primary target of oral anticoagulants (warfarin), therefore the effects of these medications are not apparent until previously-existing clotting factor turnover has occurred. Factor half-lives vary, from factor VII at 6-8 hours to factor II at 50-80 hours (234). Thus, it has a slow onset of action (8-12 hours) as existing clotting factors must be depleted, and the maximal effect occurs 3-5 days after administration. Warfarin is monitored by PT and INR, which is a normalized ratio of the patient's PT to that of a control sample (234). Age, female gender, and preexisting medical conditions such as hepatic, cardiac, and renal disease modify the patient's response to warfarin. Asian patients, for example, have higher sensitivity to warfarin and require lower doses than those patients of European descent (234). Dietary changes may alter the patient's clotting ability, and those on Warfarin are advised to avoid grapefruit and cranberry products, eat a consistent amount of leafy greens and other high 
vitamin $\mathrm{K}$ containing foods and are advised to limit herbal supplement intake of garlic, ginger, gingko biloba, ginseng, and fish oil. Warfarin may be reversed with administration of vitamin $\mathrm{K}$, which is associated with multiple side effects.

Warfarin is one of the most common drugs utilized in patients undergoing interventional techniques. Multiple complications have been reported with case reports of epidural hematoma in patients with warfarin, despite if it was stopped as per the guidelines.

Lagerkranser et al (52) reported warfarin contributing to spinal hematoma in $11 \%$ of the cases. Our report showed a total of cases of warfarin which were stopped appropriately with 2 of them also receiving enoxaparin with a similar incidence of around $10 \%$.

\subsubsection{Direct Thrombin Inhibitors}

Direct thrombin inhibitors include Dabigatran
(Pradaxa $\left.{ }^{\circledR}\right)$, Argatroban (Acova ${ }^{\mathrm{TM}}$ ), Bivalirudin (Angiomax ${ }^{\circledR}$ ), Lepirudin (Refludan $\left.{ }^{\circledR}\right)$, Desirudin (IPRIVASK®), and Hirudin as shown in Table 16. Of all the direct thrombin inhibitors, Dabigatran may be reversed by Idarucizumab (Praxbind $\Theta$ ), which was approved in 2015.

Dabigatran etexilate is an oral anticoagulant and is a prodrug that is converted to dabigatran in the plasma. After an oral dose, the peak effect is reached within 2 to four hours, and plasma half-life is 13 hours on average (235). Dabigatran dose recommendations depend on renal efficacy in the patient receiving the medication. In those with a creatinine clearance of greater than $30 \mathrm{~mL}$ minute, $150 \mathrm{mg}$ is taken orally twice daily. For patients with lower creatinine clearance, $75 \mathrm{mg}$ twice daily is recommended. Dabigatran's function is via factor inhibition and not clotting factor depletion, thus, the administration of clotting factors is anticipated to be less effective in reversing the effects of dabigatran. Dabigatran

Table 16. Comparative pharmacokinetics/pharmacodynamics of direct thrombin inhibitor.

\begin{tabular}{|c|c|c|c|c|c|c|}
\hline & $\begin{array}{c}\text { Dabigatran } \\
\text { (Pradaxa) }\end{array}$ & $\begin{array}{c}\text { Argatroban } \\
\text { (Acova) }\end{array}$ & $\begin{array}{l}\text { Bivalirudin } \\
\text { (Angiomax) }\end{array}$ & $\begin{array}{l}\text { Lepirudin } \\
\text { (Refludan) }\end{array}$ & $\begin{array}{c}\text { Desirudin } \\
\text { (IPRIVASK) }\end{array}$ & Hirudin \\
\hline Target & $\begin{array}{l}\text { Direct thrombin } \\
\text { inhibitor }\end{array}$ & $\begin{array}{l}\text { Direct thrombin } \\
\text { inhibitor }\end{array}$ & $\begin{array}{l}\text { Reversible } \\
\text { direct thrombin } \\
\text { inhibitor }\end{array}$ & $\begin{array}{l}\text { Direct thrombin } \\
\text { inhibitor }\end{array}$ & $\begin{array}{l}\text { Direct thrombin } \\
\text { inhibitor }\end{array}$ & $\begin{array}{c}\text { Naturally } \\
\text { occurring peptide } \\
\text { anticoagulant }\end{array}$ \\
\hline Time to Cmax & 2-4 hours & 1-3 hours & 2 minutes & 4 hours & 1-3 hours & 3 hours \\
\hline $\begin{array}{l}\text { Time to peak } \\
\text { effect }\end{array}$ & $0.5-2$ hours & 2 hours & $15 \mathrm{~min}$ & $0.5-2$ hours & 2 hours & 3-4 hours \\
\hline Metabolism & $\begin{array}{c}\text { Metabolized via } \\
\text { conjugation into } 4 \\
\text { acyl glucuronides, } \\
\text { not mediated by } \\
\text { CYP450 }\end{array}$ & CYP3A4 & $\begin{array}{l}\text { Proteolytic } \\
\text { cleavage }\end{array}$ & $\begin{array}{l}\text { Lepirudin is } \\
\text { thought to be } \\
\text { metabolized by } \\
\text { release of amino } \\
\text { acids via catabolic } \\
\text { hydrolysis of the } \\
\text { parent drug }\end{array}$ & $\begin{array}{c}\text { Metabolized by } \\
\text { stepwise degradation } \\
\text { from the C-terminus } \\
\text { possibly catalyzed by } \\
\text { carboxypeptidase(s) } \\
\text { such as } \\
\text { carboxypeptidase A }\end{array}$ & $\begin{array}{l}\text { Proteolytic } \\
\text { cleavage }\end{array}$ \\
\hline Bioavailability & 3-7\%(Oral) & $100 \% \mathrm{IV}$ & $\begin{array}{c}100 \% \text { IV } \\
\text { application only }\end{array}$ & $\begin{array}{c}100 \% \text { (injection } \\
\text { or infusion) }\end{array}$ & $100 \%$ & $100 \%$ IV \\
\hline Protein binding & $35 \%$ & $54 \%$ & no & $\mathrm{n} / \mathrm{a}$ & $\mathrm{n} / \mathrm{a}$ & $\mathrm{n} / \mathrm{a}$ \\
\hline Plasma half-life & 13 hours & 50 minutes & $\begin{array}{l}\sim 25 \text { minutes in } \\
\text { patients with } \\
\text { normal renal } \\
\text { function }\end{array}$ & 1.3 hours & 2-3 hours & 80 minutes \\
\hline Renal elimination & $80 \%$ urine & Liver & Yes & Yes & Yes & $\begin{array}{l}\text { Renal, about } 48 \% \\
\text { (35\% unchanged) }\end{array}$ \\
\hline Linear PK & Yes & Yes & Yes & Yes & Yes & Yes \\
\hline $\begin{array}{l}\text { Time to } 50 \% \\
\text { recovery of } \\
\text { thrombin } \\
\text { function }\end{array}$ & 12 hours & 2 hours & 0.5 hours & 1.5 hours & 2 hours & 2 hours \\
\hline Reversal agents & Praxbind & NA & NA & NA & NA & NA \\
\hline
\end{tabular}

CYP = cytochrome P450; IV = intravenous 
is mostly cleared by the kidneys. In those with normal kidney function, Dabigatran is excreted in 1-2 days postdiscontinuation. This also depends on renal sufficiency of the patient taking the medication. There is one case report with epidural hematoma despite its discontinuation for 7 days prior to interventional techniques (152). Lagerkranser et al (52) also reported on a case of spinal hematoma out of 160 cases.

Argatroban is a small molecule direct thrombin inhibitor that is administered intravenously. It reaches steady-state plasma concentrations in 1-3 hours and is metabolized via the liver. It has a half-life of 50 minutes and is monitored by PTT. As it is metabolized hepatically, it is a viable alternative for Dabigatran, which is metabolized renally (236).

Bivalirudin works by binding specifically to the catalytic site, in addition to the anion-binding exosite of circulating and clot-bound thrombin. Bivalirudin is cleared by the kidney and thus is dose-dependent on overall renal function. It has as a half-life of 25 minutes in those with normal renal function, but this may be doubled in those with severe renal insufficiency (237).

Desirudin is a subcutaneously administered direct thrombin inhibitor and is indicated for the prevention of venous thromboembolism after total joint replacement. It is recommended that dosage adjustment and aPTT be monitored in patients with moderate-to-severe renal impairment. After intravenous administration, desirudin is removed rapidly via the renal system, with $90 \%$ of the dose removed from the plasma within two hours. Plasma concentrations decline with a mean halflife of 2-3 hours. Subcutaneous administration demonstrates a half-life of 2 hours (238).

Hirudin has specific activity on fibrinogen and binds to and inhibits only activated thrombin, making it an extremely potent direct thrombin inhibitor. Thus, hirudin dissolves the formation of clots and thrombi and has therapeutic value in coagulation disorders. It is also able to act on complexed thrombin and does not alter other serum protein function or activity (239). Hirudin has a half-life of 2-3 hours and is monitored by aPTT, allowing close titration over a wide range of anticoagulative clinical desires. Activated clotting time (ACT) and prothrombin time (PT) are insensitive for monitoring hirudin .

\subsubsection{Direct Factor Xa Inhibitors}

Direct factor $X a$ inhibitors such as Rivaroxaban (Xarelto $囚$ ) have been commonly used in the United States (Table 17). Of multiple $\mathrm{Xa}$ inhibitors available, apixaban (Eliquis) and rivaroxaban (Xarelto) can be reversed by Andexanet alfa (Andexxa $®$ ), a coagulation factor Xa (recombinant), which has been approved by the FDA for the urgent reversal of the anticoagulant effect in 2018 (240).

Rivaroxaban (Xarelto) has dual renal and hepatic clearance, with around one-third of the drug being active with each route of metabolism. This dual route of clearance makes accumulation less likely than other medications that are solely hepatically or renally

Table 17. Comparative pharmacokinetics/pharmacodynamics of direct factor Xa inhibitor.

\begin{tabular}{|c|c|c|c|c|c|}
\hline & $\begin{array}{c}\text { Apixaban } \\
\text { (Eliquis) }\end{array}$ & $\begin{array}{c}\text { Rivaroxaban } \\
\text { (Xarelto) }\end{array}$ & $\begin{array}{c}\text { Edoxaban } \\
\text { (Savaysa, Lixiana) }\end{array}$ & $\begin{array}{c}\text { Betrixaban } \\
\text { (Bevyxxa) }\end{array}$ & $\begin{array}{l}\text { Fondaparinux } \\
\text { (Arixtra) }\end{array}$ \\
\hline Target & $\mathrm{Xa}$ & $\mathrm{Xa}$ & $\mathrm{Xa}$ & $\mathrm{Xa}$ & $\mathrm{Xa}$ \\
\hline Time to Cmax & 1-3 hours & 2-4 hours & 1-2 hours & 3-4 hours & 2 hours \\
\hline Time to peak effect & 3-4 hours & 2-4 hours & 1-2 hours & 3-4 hours & 2-3 hours \\
\hline CYP Metabolism & $15 \%$ & $32 \%$ & NR & NR & $\mathrm{n} / \mathrm{a}$ \\
\hline Bioavailability & $66 \%$ & $80 \%$ & $>45 \%$ & $34 \%$ & $100 \%$ \\
\hline Transporter & P-gp & P-gp/BCRP & P-gp & P-gp & P-gp \\
\hline Protein binding & $87 \%$ & $>90 \%$ & $55 \%$ & $60 \%$ & $94 \%$ \\
\hline Plasma Half-life & 8 - 15 hours & 9-13 hours & 8-10 hours & 37 hours & 17-21 hours \\
\hline Renal elimination & $25 \%$ & $33 \%$ & $35 \%$ & $<1 \%$ & $100 \%$ \\
\hline Linear PK & Yes & No & Yes & $\mathrm{n} / \mathrm{a}$ & Yes \\
\hline $\begin{array}{l}\text { Time to } 50 \% \text { recovery } \\
\text { of Xa }\end{array}$ & 12 hours & 12 hours & 12 hours & 19-27 hours & 12 hours \\
\hline Reversal AGENTS & Andexxa & Andexxa & NA & $\mathrm{NA}$ & NA \\
\hline
\end{tabular}

$\mathrm{BCRP}=$ breast cancer resistance protein; $\mathrm{CYP}=$ cytochrome P450; NR - not reported; P-gp = P-glycoprotein 
cleared. Rivaroxaban is orally administered and has a half-life of 5.7 to 9.2 hours. Plasma protein binding of rivaroxaban is $92-95 \%$. One third of the absorbed dose is excreted in the urine, and two-thirds of the dose is excreted as an inactive metabolite in the feces and urine. Rivaroxaban has the potential for drug interactions with medications that are P-glycoprotein inhibitors and those metabolized by CYP3A4 (241).

Apixaban (Eliquis $囚$ ) is a specific factor Xa inhibitor like its counterpart, rivaroxaban. It is rapidly absorbed and reaches peak concentrations in 1-2 hours $(242,243)$. Apixaban has an oral availability of $45 \%$ and has a relatively complex elimination pathway with both direct renal and intestinal excretion, with the latter being the majority $(243,244)$. Edoxaban (Savaysa $\AA$ or Lixiana $\AA$ ) was approved for prevention of venous thromboembolisms following lower limb orthopedic surgery in 2011 and is an oral direct factor Xa inhibitor that inhibits free factor A and prothrombinase activity. It has also been approved for the prevention of stroke and systemic embolism. Peak plasma concentrations are reached 1.5 hours after oral administration, and it has an elimination half-life of 10-14 hours when taken at $60 \mathrm{mg}$ once daily. It is excreted via both hepatic and renal systems (245). It is orally available, and not removed by dialysis.

Betrixaban (Bevyxxa®) is a potent oral factor $\mathrm{Xa}$ inhibitor that recently received FDA approval. It has exemplified promising results, as it has low hERG affinity and has reduced bleeding risk and prevented thromboembolism in clinical trials for orthopedic knee surgery (246-248). Betrixaban has the smallest percent of renal clearance, is INR/PTT insensitive, and has minimal liver metabolism. Another selective factor $\mathrm{Xa}$ inhibitor, Fondaparinux (Arixtra ${ }^{\circledR}$ ) is $100 \%$ bioavailable and achieves maximum concentration in 1.7 hours of administration (249). Its extended half-life of 17 to 21 hours allows once-daily dosing (250).

There were no case reports in the present assessment; however, Lagerkranser et al (52) showed 2 cases of spinal hematoma with rivaroxaban yielding $1.3 \%$ prevalence among 160 cases developing spinal hematoma.

\subsubsection{Thrombolytic Agents}

Fibrinolysis is caused by thrombolytic agents via conversion of plasminogen and thrombi to plasmin in order to destroy clots. These "clot busters" such as recombinant tissue-type plasminogen activator (tPA), streptokinase, urokinase, tenecteplase, and reteplase are enzymes that have effects on both circulating and tissue type plasminogen. The half-life of these thrombolytic drugs is generally a few hours, but the inhibition of plasminogen and fibrinogen may last for up to 27 hours after administration (251).

There were no reports of epidural hematoma development in patients receiving thrombolytic agents in our analysis; however, Lagerkranser et al (52) reported 4 cases or $2.5 \%$ in the review of 160 cases of spinal hematoma. Among the miscellaneous agents, Chien et al (132) reported a case of epidural hematoma in a patient receiving fluoxetine, fish oil, and vitamin $\mathrm{E}$. There was also another case report by Jenkie et al (137) with fish oil and the development of cervical epidural hematoma leading to surgical intervention for decompression. Lagerkranser et al (52) also reported one patient on selective serotonin receptor inhibitor of 160 cases.

\subsubsection{Herbal/Alternative Therapies}

Garlic has a dose-dependent effect on bleeding, as it contains a compound called ajoene. Derived from allicin, the compound that provides garlic's flavor, ajoene inhibits granule release and fibrinogen binding and additionally inhibits aggregation of platelets via a variety of mechanisms. Prostacyclin, forskolin, indomethacin, and dipyridamole are all altered via ajoene's inhibition of granule release $(252,253)$. Ginkgo Biloba has been used for thousands of years, and its mechanism is not entirely understood. Ginkgo is thought to antagonize platelet activating factor (PAF) and collagen leading to inhibition of platelet aggregation, resulting in several reports of spontaneous bleeding. Flavonol glycosides and terpene glycosides have been suggested to be the chemical compounds responsible for the increased bleeding events after intake of this medication (254). Ginseng is commonly used and reduces the effect of warfarin, declining peak INR levels. Ginsenosides are the major active ingredient of ginseng, and possibly induce cytochrome P450 enzymes to increase the metabolism of Warfarin and thus reduce its effect.

\subsection{Recommendations}

Based on the evidence from review of the current literature with inclusion of available studies (1), case reports (38), multiple guidelines and reviews (1,20,3142,122-129) and consensus, the evidence appears as follows:

1. There is good evidence for risk stratification by categorizing multiple interventional techniques into low-risk, moderate-risk, and high-risk. Also, 
their risk should be upgraded based on other risk factors.

2. There is good evidence for the risk of thromboembolic events in patients who interrupt antithrombotic therapy.

3. There is good evidence supporting discontinuation of low dose aspirin for high risk and moderate risk procedures for at least 3 days, and there is moderate evidence that these may be continued for low risk or some intermediate risk procedures.

4. There is good evidence that discontinuation of anticoagulant therapy with warfarin, heparin, dabigatran (Pradaxa $\AA$ ), argatroban (Acova $₫$ ), bivalirudin (Angiomax ${ }^{\circledR}$ ), lepirudin (Refludan $®$ ), desirudin (Iprivask $®$ ), hirudin, apixaban (Eliquis $®$ ), rivaroxaban (Xarelto ${ }^{\circledR}$ ), edoxaban (Savaysa ${ }^{\circledR}$, Lixiana $\AA)$, Betrixaban $($ Bevyxxa $®)$, fondaparinux (Arixtra ${ }^{\circledR}$ ) prior to interventional techniques with individual consideration of pharmacokinetics and pharmacodynamics of the drugs and individual risk factors increases safety.

5. There is good evidence that diagnosis of epidural hematoma is based on severe pain at the site of the injection, rapid neurological deterioration, and MRI with surgical decompression with progressive neurological dysfunction to avoid neurological sequelae.

6. There is good evidence that if thromboembolic risk is high, low molecular weight heparin bridge therapy can be instituted during cessation of the anticoagulant, and the low molecular weight heparin can be discontinued 24 hours before the pain procedure.

7. There is fair evidence that the risk of thromboembolic events is higher than that of epidural hematoma formation with the interruption of antiplatelet therapy preceding interventional techniques, though both risks are significant.

8. There is fair evidence that multiple variables including anatomic pathology with spinal stenosis and ankylosing spondylitis; high risk procedures and moderate risk procedures combined with anatomic risk factors; bleeding observed during the procedure, and multiple attempts during the procedures increase the risk for bleeding complications and epidural hematoma.

9. There is fair evidence that discontinuation of phosphodiesterase inhibitors is optional (dipyridamole [Persantine], cilostazol [Pletal]. However, there is also fair evidence to discontinue Aggrenox [dipyri- damole plus aspirin]) 3 days prior to undergoing interventional techniques of moderate and high risk.

10. There is fair evidence to make shared decision making between the patient and the treating physicians with the treating physician and to consider all the appropriate risks associated with continuation or discontinuation of antithrombotic or anticoagulant therapy.

11. There is fair evidence that if thromboembolic risk is high antithrombotic therapy may be resumed 12 hours after the interventional procedure is performed.

12. There is limited evidence that discontinuation of antiplatelet therapy (clopidogrel [Plavix $\circledast$ ], ticlopidine [Ticlid $₫$ ], Ticagrelor [Brilinta $\Theta$ ] and prasugrel [Effient $\Theta]$ ) avoids complications of significant bleeding and epidural hematomas.

13. There is very limited evidence supporting the continuation or discontinuation of most NSAIDs, excluding aspirin, for 1 to 2 days and some 4 to 10 days, since these are utilized for pain management without cardiac or cerebral protective effect.

Table 18 shows guidelines for antithrombotic medication management during interventional spine procedures. This table also shows comparisons of ASIPP proposed guidelines and ASRA published guidelines. These recommendations differ from our previously published guidelines, as well as from ASRA guidelines based on the present analysis of the evidence.

General recommendations based on ASRA guidelines (40) are to discontinue the drugs for 5 half-lives; however, the exception to the 5 half-lives recommendation should occur in individuals with hepatic dysfunction, and renal dysfunction including nephrotic syndrome.

\subsection{Discussion and Literature Review}

\subsection{Risk/Benefits of Antithrombotic Therapy}

Cardiovascular disease in the United States contributes to the most mortality with 610,000 deaths per year contributing to one in every 4 deaths (58). Thrombotic complications contribute a significant proportion of cardiovascular related deaths. Various disorders contributing to thrombotic complications include atherosclerotic cardiovascular disease, defined as acute coronary syndrome, ischemic heart disease, peripheral arterial disease, atrial fibrillation, and multiple other 
Pain Physician: Guidelines Issue 2019; 22:S75-S128

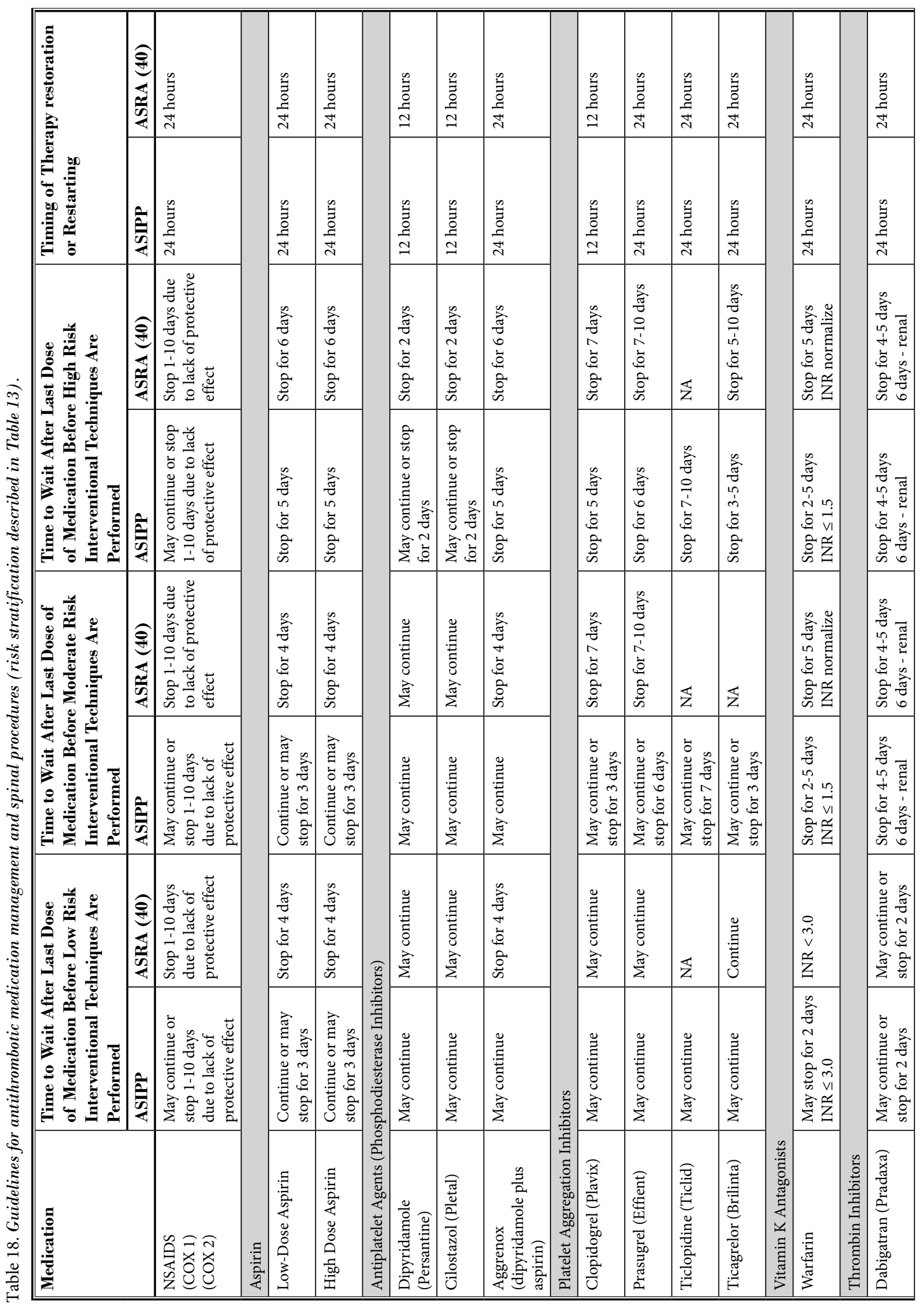




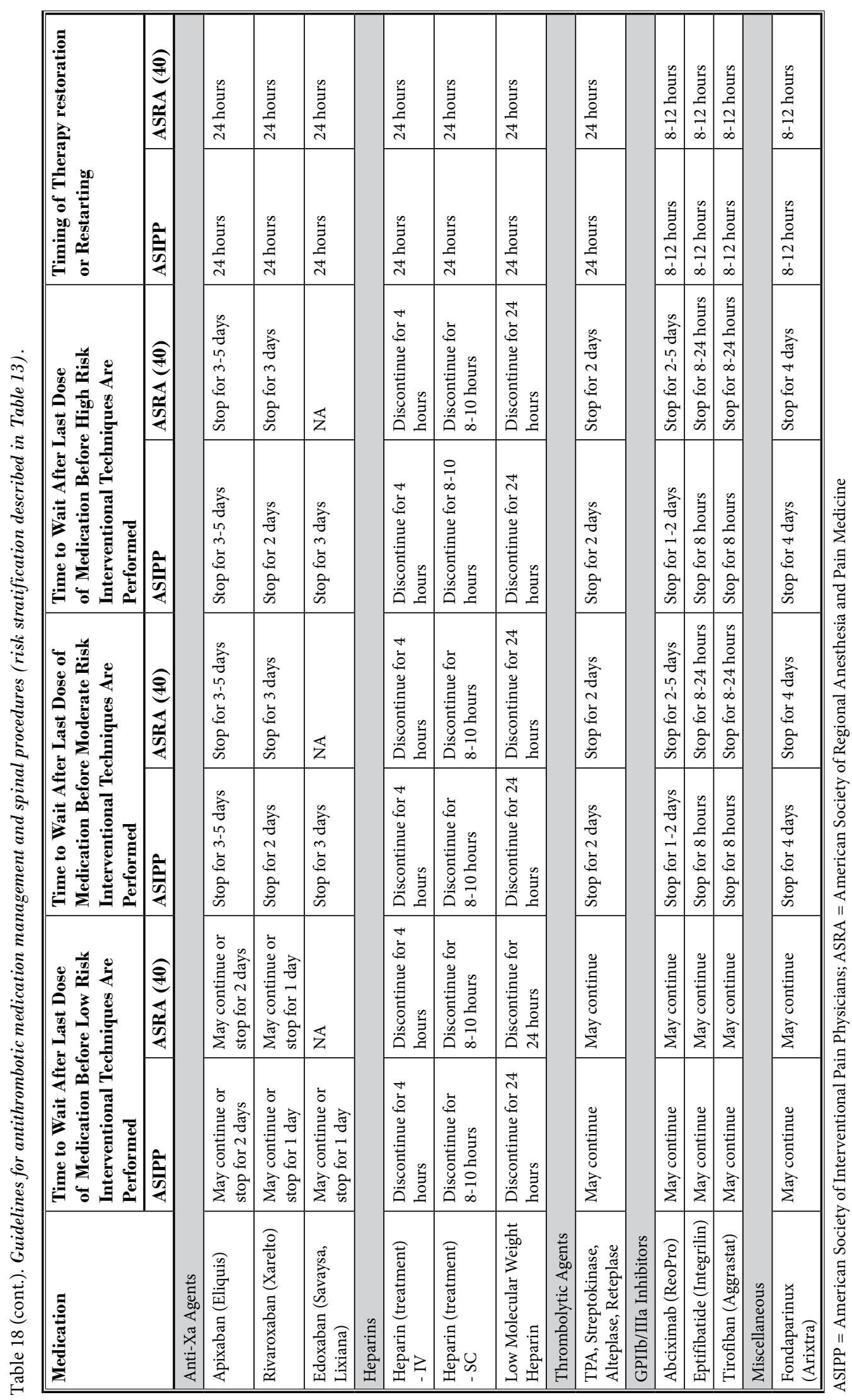


ailments. These patients are widely prescribed with anticoagulants and antithrombotics in over $10 \%$ of the patients undergoing surgery or invasive procedures $(255,256)$. However, a significant proportion of these patients may also undergo invasive procedures resulting in significant controversy. Significant risks have been described by withdrawing antiplatelet therapy, which included cardiovascular, cerebrovascular, and peripheral vascular thrombosis. In fact, a systematic review (69) showed a 3-fold increased risk for major adverse cardiac events and that the risk was magnified in patients with coronary stents.

Estimates suggest that greater than two-thirds of sudden cardiac events (acute coronary syndrome or sudden cardiac death) and half of the postoperative myocardial infarctions follow initiation of an arterial plaque disruption and associated thrombosis (256-261). Parallel clinical data on cerebrovascular events are not known; however, acute coronary syndrome is associated with pro-inflammatory and pro-thrombotic states, which involve elevated levels of fibrinogen, C-reactive protein, and plasminogen activator inhibitor (262). In the postoperative period, endogenous catecholamines, increased platelet adhesiveness, and decreased fibrinolysis increase the risk of an acute coronary syndrome $(256,260,263)$.

There is evidence that discontinuation or interruption of antiplatelet therapy may result in hypercoagulability with thrombosis or bleeding $(69,264-273)$. Studies have determined that maintaining antiplatelet therapy throughout surgery is associated with an increase in blood loss of $2.5 \%$ to $20 \%$ with aspirin and $30 \%$ to $50 \%$ with a combined therapy of aspirin and clopidogrel $(273,274)$. Importantly, this increased blood loss has not been shown to correlate with increased mortality, except in intracranial surgery $(267,273)$. Reports indicate an average increase of $30 \%$ in the transfusion rate, with a complication rate from red blood cell transfusion of $0.4 \%$ (275) and mortality linked directly to massive surgical blood loss in less than $3 \%$ of reported clinical data (276). However, an important recognized risk of withdrawing antiplatelet therapy has been described via a rebound effect with increased platelet adhesiveness (277-280). This phenomenon is also a consequence of the systemic inflammatory response and the acute phase reaction to surgery, which also increases platelet adhesiveness and decreases fibrinolysis $(257,260,281)$. It should also be noted that comorbid pathologies, such as carcinoma and diabetes, can also contribute to the prothrombotic state. Death and infarction rates in acute coronary syndrome were doubled in the setting of drug withdrawal (279). Further, during the important period of re-endothelialization after coronary stent implantation, myocardial infarction rates up to $85 \%$ have been reported (282), along with a 5-10 fold increase in the perioperative mortality. In comparison, existing literature has reported average stent thrombosis of $35 \%$ and the average mortality from stent thrombosis of $20 \%$ to $40 \%(257,283)$ without noncardiac surgery.

The questions have been raised in reference to withholding antithrombotic therapy prior to interventions and associated risks. Chassot et al (257) proposed to modify the practice of withholding patients from all antiplatelet agents 7 to 10 days prior to surgery, except when bleeding might occur in a closed cavity. Chassot et al (257) conducted an extensive review of the literature and reasoned that in the absence of prior clinical data on different antiplatelet regimens during noncardiac surgery, including low coronary risk situations, patients on antiplatelet drugs should continue therapy throughout surgery, except when bleeding might occur in a closed space. Another proposed consideration is the use of a therapeutic bridge utilizing antiplatelet drugs with shorter durations of action. In fact, other comprehensive reviews have offered variable guidance $(27,31,32,34,49,54,124-129,147,149,212,251,284-$ 299) on anticoagulation management. One systematic review (299), which evaluated 31 reports determined that for dental procedures, arthrocentesis, cataract surgery, and diagnostic endoscopy most patients can proceed without alteration to their anticoagulant therapy. Several publications also delineated a variety of other procedures, including endoscopy $(300,301)$, peripheral vascular surgery (302), and ophthalmic surgery (303) with no evidence of increased bleeding when patients are continued on antiplatelet therapy throughout the perioperative period. Gerstein et al (304) also showed that for many other procedures, minimal perioperative bleeding risk occurred when aspirin was continued, contrasted with concomitant thromboembolic risks associated with aspirin withdrawal.

The risk of thromboembolic events may be a more significant clinical feature, versus the risk of epidural hematoma. A majority of regional anesthesia and interventional pain management literature has focused on the risks of epidural hematoma, paying only scant attention to thromboembolic events. However, wider evidence in the literature defines multiple guidelines from other specialties that described continuation of 
antiplatelet therapy during surgical interventions, including peripheral vascular surgery, with some high-risk exceptions (267-277,282,299-303,305).

These data suggest the traditional attitude of discontinuing anti-clotting medications 10 days before interventions poses considerable clinical risk (268$273,277,282)$. Multiple prior guidelines have recommended discontinuation of anti-thrombosis therapy and this has shaped general practice to discontinue these drugs $(40,174,251)$. Thus, despite absence of evidence of significant bleeding risk during interventional techniques in patients with antithrombotic therapy $(37,251,284,285)$, they are routinely discontinued. Importantly, neither continuation nor discontinuation of antithrombotic therapy comes without risk $(199,200,212,251,306-311)$. While most available clinical case reports focus on regional anesthesia for surgical procedures, additional evidence have been provided in the literature relating to epidural hematoma in patients undergoing interventional techniques for chronic pain with or without antithrombotic therapy - continued or discontinued $(31,32,37,38,113-116,182,183,185$ $191,193,195,196,199,200,212,251,284,285,306-312)$.

In fact, the evidence based on this analysis for discontinuing antithrombotic agents is very weak. Evidence is stronger for the continuation for antithrombotic therapy since the majority of epidural hematomas have occured in patients either not on antithrombotic agents or in patients whose therapy had been appropriately discontinued.

\subsection{Anatomical Considerations}

Multiple factors herein described, including anatomy of the epidural space, spinal anatomy, coexisting pathology, coagulation status, needle placement, and injectate can affect the development of hematomas. A meta-analysis of over 600 spinal hematomas including both spontaneous and iatrogenic cases, revealed anticoagulation to be the second most common underlying etiology, closely following idiopathic occurrence without identifiable cause (313). In this meta-analysis, spinal and epidural anesthetic procedures in combination with anticoagulation represented the fifth highest cause of epidural hematomas. However, among this group of patients, spinal hematomas were most commonly encountered in those receiving continuous and not single-shot epidural anesthesia $(314,315)$. As shown in Table 10, Lagerkranser (52) has shown patient-related risk factors in their study of 166 case reports of spinal hematoma from 1994 through 2015. Spinal stenosis was the most common diagnosis with ankylosing spondylitis taking the third place in relation to anatomic factors.

The evidence from the present analysis also shows spinal stenosis as a major risk factor associated with technical factors of bleeding and multiple attempts.

\subsection{Drug-Related Risk Factors}

Drug-related factors are considered to be the most common risk factors. Continuation or discontinuation of antiplatelets and antithrombotic drugs was reported in the majority of the patients in this assessment (63\%). In addition, earlier studies also showed these as the most common risk factors. Lagerkranser (52) described drug-related factors as the highest with frequencies as shown in Table 11. He reported intake of anti-hemostatic drugs in $63 \%$ of the patients, whereas more than one anti-hemostatic drug was implicated in 47 of 166 cases.

\subsection{Bridge Therapy}

Those undergoing chronic anticoagulation often require interruptions due to a procedure or other medical issue for various durations. The decision to bridge with heparin or other anticoagulants is a common clinical problem for those undergoing oral anticoagulation, especially in the case of interventional anesthesia. The evidence to inform decision making is limited, making current guidelines equivocal and imprecise. New randomized controlled studies have shown significant perioperative or periprocedural bleeding rates without reduction in thromboembolism when bridging is completed (314-317). Additional studies such as PERIOP2 (318) outlining guidelines for high risk individuals in need for bridging have made it somewhat clearer that only those with significant thromboembolism risk benefit from bridge therapy. Bridging anticoagulation may be vital for patients with a high risk for thromboembolism, but for most patients it produces excessive bleeding which leads to longer hospital stays and significant comorbidities without any difference in prevention of thromboembolism (319).

\subsection{Reversal of Antithrombotic and Anticoagulant Agents}

While immediate reversal for interventional pain procedures is rare, anticoagulation reversal and treatment options should be discussed in relation to major bleeding. Options include protamine, phytonadione (Vitamin K), hemodialysis, oral-activated charcoal, antifibrinolytic agents including tranexamic acid, 
desmopressin, blood products including packed red blood cells (PRBCs) and platelets, prothrombin complex concentrates (PCCs), and specific reversal agents. For example, Idarucizumab is the only FDA-approved reversal agent for direct oral anticoagulants, specifically dabigatran. Andexanet alfa does the same for both oral and injectable factor $X a$ inhibitors. Prothrombin complex concentrates have been developed to contain highly concentrated coagulation factors along with antithrombotic agents. They are quite successful in the reversal of vitamin $\mathrm{K}$ antagonists (VKAs) and are considered first line treatment in patients with major bleeding on VKAs. Fresh Frozen Plasma traditionally has been used for VKAs as it contains all members of the coagulation cascade. It is not as beneficial for direct oral anticoagulants as these medications directly target and inactivate specific factors. The amount of FFP needed is estimated to be nearly two liters in order to appropriately establish previous concentrations of the respective factor (320).

\section{Acknowledgments}

The authors wish to acknowledge the recent passing of Phillip J. Kadowitz, PhD, Professor at Tulane School of Medicine, Department of Pharmacology and Adjunct Professor at the Louisiana State University Health Science Center, Department of Anesthesiology for his lifelong teaching of medical students, graduate students, and residents over a fifty plus year career. One of his PhD graduate students was Alan D. Kaye, MD, $\mathrm{PhD}$.

The authors would like to thank statistician Vidyasagar Pampati, MSc; Bert Fellows, MA, Director Emeritus of Psychological Services, for manuscript review, and transcriptionists Tonie M. Hatton and Diane E. Neihoff, for their assistance with the preparation of this manuscript. We would also like to thank the editorial board of Pain Physician for their suggestions to improve this manuscript.

\section{Disclosures}

Funding: There was no external funding in the preparation of this manuscript.

\section{Author Affiliations}

${ }^{1}$ Dr. Kaye is Professor, Program Director, and Chairman, Department of Anesthesiology, Louisiana State University Health Science Center, New Orleans, LA.

${ }^{2}$ Dr. Manchikanti is Medical Director of the Pain Management Center of Paducah, Paducah, KY, Clinical
Professor, Anesthesiology and Perioperative Medicine, University of Louisville, Louisville, KY, and Professor of Anesthesiology-Research, Department of Anesthesiology, School of Medicine, LSU Health Sciences Center, New Orleans, LA.

${ }^{3}$ Mr. Novitch, Medical College of Wisconsin, Wausau, WI.

${ }^{4} \mathrm{Mr}$. Mungrue, Department of Pharmacology \& Experimental Therapeutics, Louisiana State UniversityHealth Sciences Center-New Orleans, LA.

${ }^{5} \mathrm{Mr}$. Anwar, Department of Anesthesiology, Tulane Medical Center Center-New Orleans, LA.

${ }^{6} \mathrm{Dr}$. Jones, Department of Anesthesia, Critical Care and Pain Medicine, Beth Israel Deaconess Medical Center, Harvard Medical School, Boston, MA.

${ }^{7} \mathrm{Mr}$. Helander, Department of Anesthesiology, Louisiana State University-Health Sciences Center-New Orleans, LA.

${ }^{8}$ Dr. Cornett, Assistant Professor, Departments of Anesthesiology and Pharmacology, Toxicology and Neuroscience, Director of Research, Department of Anesthesiology, Assistant Professor of Research, Department of Anesthesiology, Louisiana State University-Health Sciences Center-New Orleans, LA and Shreveport, LA.

${ }^{9}$ Dr. Eng, Department of Anesthesiology, Louisiana State University-Health Sciences Center-New Orleans, LA.

${ }^{10} \mathrm{Dr}$. Grider is Associate Chief Medical Officer of Ambulatory Services, Medical Director of UK HealthCare Pain Services, and Professor of the Department of Anesthesiology, University of Kentucky College of Medicine, Lexington, KY.

${ }^{11} \mathrm{Dr}$. Harned is Associate Professor with the Department of Anesthesiology, Division of Pain Medicine, and Division Chief of Interventional Pain Medicine at the University of Kentucky College of Medicine, Lexington, $\mathrm{KY}$.

${ }^{12}$ Dr. Benyamin is Medical Director, Millennium Pain Center, Bloomington, IL, Clinical Assistant Professor of Surgery, College of Medicine, University of Illinois, Urbana-Champaign, IL, Department of Psychology, Illinois Wesleyan University, and Stimgenics LLC, Bloomington, IL

${ }^{13} \mathrm{Dr}$. Swicegood is Medical Director, Advanced Interventional Pain and Diagnostics of Western Arkansas, Fort Smith, AR.

${ }^{14} \mathrm{Dr}$. Simopoulos is Chief of the Division of Pain Medicine and Co-director of the Spine Center at Beth Israel Deaconess Medical Center, Assistant Professor Harvard Medical School, Boston, MA. 
${ }^{15} \mathrm{Dr}$. Abdi is Professor (Tenured) and Chair, Department of Pain Medicine, Helen Buchanan \& Stanley Joseph Seeger Endowed Research Professor, University of Texas MD Anderson Cancer Center, Houston, TX.

${ }^{16} \mathrm{Dr}$. Urman, Department of Anesthesiology, Perioperative and Pain Medicine, Brigham and Women's Hospital, Harvard Medical School, Boston, MA.

${ }^{17} \mathrm{Dr}$. Deer is President and CEO of The Center for Pain Relief, Charleston, WV, and Clinical Professor of Anesthesiology and Pain Medicine, West Virginia University School of Medicine, Charleston, WV.

${ }^{18} \mathrm{Dr}$. Bakhit is an Interventional Pain Physician at the Pain Management Center of Paducah, Paducah, KY.

${ }^{19} \mathrm{Dr}$. Sanapati is Medical Director, Advanced Care Pain Clinic, Evansville, IN.

${ }^{20} \mathrm{Dr}$. Atluri is Medical Director, Tri-State Spine Care Institute, Cincinnati, $\mathrm{OH}$.

${ }^{21}$ Dr. Pasupuleti is Medical Director, Center for Pain Management, Bowling Green, KY.

${ }^{22} \mathrm{Dr}$. Soin is Medical Director, Ohio Pain Clinic, Centerville, $\mathrm{OH}$, Clinical Assistant Professor of Surgery at Wright State University, Dayton, $\mathrm{OH}$, and Assistant Professor, Ohio University College of Medicine, Athens, $\mathrm{OH}$.

${ }^{23}$ Dr. Diwan is President, Park Avenue Spine and Pain, New York, NY.

${ }^{24} \mathrm{Dr}$. Vallejo is Director of Research, Millennium Pain Center, Bloomington, IL, Adjunct Research, Psychology Department, Wesleyan University, Normal, IL.

${ }^{25} \mathrm{Dr}$. Candido is Chairman, Department of Anesthesiology, Advocate Illinois Masonic Medical Center, Professor of Clinical Anesthesiology, and Clinical Professor of Surgery, University of Illinois College of Medicine, Chicago, IL.

${ }^{26} \mathrm{Dr}$. Knezevic is Vice Chair for research and Education; Department of Anesthesiology; Advocate Illinois Masonic Medical Center, Chicago, IL and Associate Professor of Anesthesiology and Surgery, College of Medicine, University of Illinois, Chicago, IL.

${ }^{27} \mathrm{Dr}$. Beall is Chief of Radiology Services, Clinical Radiology of Oklahoma, Oklahoma City, OK.

${ }^{28} \mathrm{Dr}$. Albers is Director of Research, Radiology Research and Consultation, Sacramento, CA.
${ }^{29} \mathrm{Dr}$. Latchaw is a Professor of Radiology, Department of Radiology, UC-Davis Medical Center, Sacramento, CA.

${ }^{30} \mathrm{Dr}$. Prabhakar is a Pain Fellow in the Department of Anesthesiology, Critical Care, and Pain Medicine at Massachusetts General Hospital, Boston, MA

${ }^{31} \mathrm{Dr}$. Hirsch is Vice Chair and Service Line Chief of Interventional Radiology, Chief of Neurolnterventional Spine, Director Interventional Neuroradiology, Massachusetts General Hospital and Harvard Medical School, Boston, MA.

\section{Conflicts of Interest}

Dr. Kaye is a speaker for Depomed, Inc. and Merck.

Dr. Manchikanti has provided limited consulting services to Semnur Pharmaceuticals, Incorporated, which is developing nonparticulate steroids.

Dr. Grider is a consultant for Medtronic and Abbott and is an Intralink Spine medical advisory board shareholder.

Dr. Harned receives payment for development of educational presentations from Medtronic and honorarium frm St. Jude Medical.

Dr. Benyamin is a paid consultant for Medtronic Inc., Vertiflex Inc., Vertos Medical Inc.

Dr. Simopoulos is a consultant for Nevro Corp, St. Jude Medical, and Boston Scientific.

Dr. Urman reports grants and personal fees from Merck, grants from Mallinckrodt, grants from Medtronic, outside the submitted work.

Dr. Deer is a consultant for Axonics, Bioness, Abbott, Nevro, Jazz Pharm, SpineThera, Saluda, Medtronic, Vertos, Flowonix, and Ethos; minor stock/stock options with Axonics, Bioness, SpineThera, Saluda, Vertos, and Ethos; travel/accommodations expenses covered or reimburse by Abbott and Axonics; and has funded research with Saluda, Nevro, Mainstay, Abbott, Medtronic, Bioness, and JazzPharm.

Dr. Beall receives consulting fees from MII.

Dr. Hirsch is a consultant for Medtronic. 
Pain Physician: Guidelines Issue 2019; 22:S75-S128

\section{Appendix}

Appendix Table 1

Appendix Table 2

Appendix Table 3

To view pdf with Appendix links active, visit

Pain Physician journal website

to access manuscript pdf. 


\section{References}

1. Manchikanti L, Falco FJE, Benyamin RM, Caraway DL, Kaye AD, Helm II S, Wargo BW, Hansen H, Parr AT, Singh V, Swicegood JR, Smith HS, Schultz DM, Malla Y, Hirsch JA. Assessment of bleeding risk of interventional techniques: $A$ best evidence synthesis of practice patterns and perioperative management of anticoagulant and antithrombotic therapy. Pain Physician 2013; 16:SE261-SE318.

2. Jenkins AT, Kantorovich A, Burman L. Contemporary use of oral antithrombotic agents: Focus on dual and triple therapeutic approaches. Pharmacotherapy 2017; 37:1545-1564.

3. Colonna P, Andreotti F, Ageno W, Pengo $\mathrm{V}$, Marchionni N. Clinical conundrums in antithrombotic therapy management: A Delphi Consensus panel. Int J Cardiol 2017; 249:249-256.

4. Scherillo M, Cirillo P, Formigli D, Bonzani G, Calabrò P, Capogrosso P, Farina R, Lanzillo T, Mascia F, Mauro C, Tuccillo B, Bellis A, Bianchi R, Cimmino G, Piro O, Ravera A, Scotto di Uccio F, Tammaro P, Vetrano A, Trimarco B. Antiplatelet Therapy for Non-ST-Segment Elevation Myocardial Infarction in Complex "Real" Clinical Scenarios: A Consensus Document of the "Campania NSTEMI Study Group”. Angiology 2017; 68:598-607.

5. Levine $G N$, Bates ER, Bittl JA, Brindis RG, Fihn SD, Fleisher LA, Granger CB, Lange RA, Mack MJ, Mauri L, Mehran R, Mukherjee D, Newby LK, O'Gara PT, Sabatine MS, Smith PK, Smith SC Jr. 2016 ACC/AHA guideline focused update on duration of dual antiplatelet therapy in patients with coronary artery disease. J Am Coll Cardiol 2016; 68:1082-1115.

6. Zhao Q, Zhu Y, Xu Z, Cheng Z, Mei J, Chen X, Wang X. Effect of ticagrelor plus aspirin, ticagrelor alone, or aspirin alone on saphenous vein graft patency 1 year after coronary artery bypass grafting: A randomized clinical trial. JAMA 2018; 319:1677-1686.

7. Johnston SC, Easton JD, Farrant $M$, Barsan W, Conwit RA, Elm J, Kim AS, Lindblad AS, Palesch YY; Clinical Research Collaboration, Neurological Emergencies Treatment Trials Network, and the POINT Investigators. Clopidogrel and aspirin in acute ischemic stroke and high-risk TIA. N Engl J Med 2018; 379:215-225.

8. Grotta JC. Antiplatelet therapy after ischemic stroke or TIA. N Engl J Med 2018; 379:291-292.
9. Alexander $\mathrm{JH}$. Ticagrelor following coronary artery bypass grafting: For better vein graft patency or better patient outcomes? JAMA 2018; 319:1661-1662.

10. Roule $V$, Blanchart $K$, Humbert $X$, Legallois D, Lemaitre A, Milliez P, Beygui F, Alexandre J. Antithrombotic therapy for ACS in elderly patients. Cardiovasc Drugs Ther 2017; 31:609-618.

11. Proietti M, Romanazzi I, Romiti GF, Farcomeni A, Lip GYH. Real-world use of Apixaban for stroke prevention in atrial fibrillation: A systematic review and meta-analysis. Stroke 2018; 49:98-106.

12. Johnston A, Jones WS, Hernandez AF. The ADAPTABLE Trial and aspirin dosing in secondary prevention for patients with coronary artery disease. Curr Cardiol Rep 2016; 18:81.

13. Goes R, Muskens IS, Smith TR, Mekary RA, Broekman $\mathrm{mL}$, Moojen WA. Risk of aspirin continuation in spinal surgery: A systematic review and meta-analysis. Spine ] 2017; 17:1939-1946.

14. Shekelle PG. Clinical practice guidelines: What's next? JAMA 2018; 320:757-758.

15. ASCEND Study Collaborative Group, Bowman L, Mafham M, Wallendszus K, Stevens W, Buck G, Barton J, Murphy K, Aung T, Haynes R, Cox J, Murawska A, Young $A$, Lay $M$, Chen $F$, Sammons $E$, Waters E, Adler A, Bodansky J, Farmer A, McPherson R, Neil A, Simpson D, Peto R, Baigent C, Collins R, Parish S, Armitage $J$. Effects of aspirin for primary prevention in persons with diabetes mellitus. $N$ Engl ] Med 2018; 379:1529-1539.

16. McNeil JJ, Nelson MR, Woods RL, Lockery JE, Wolfe R, Reid CM, Kirpach B, Shah RC, Ives DG, Storey E, Ryan J, Tonkin AM, Newman AB, Williamson JD, Margolis $\mathrm{KL}$, Ernst ME, Abhayaratna WP, Stocks $\mathrm{N}$, Fitzgerald SM, Orchard SG, Trevaks RE, Beilin LJ, Donnan GA, Gibbs P, Johnston $\mathrm{Cl}$, Radziszewska B, Grimm R, Murray AM; ASPREE Investigator Group. Effect of aspirin on all-cause mortality in the healthy elderly. N Engl J Med 2018; 379:1519-1528.

17. McNeil JJ, Wolfe R, Woods RL, Tonkin AM, Donnan GA, Nelson MR, Reid CM, Lockery JE, Kirpach B, Storey E, Shah RC, Williamson JD, Margolis KL, Ernst ME, Abhayaratna WP, Stocks N, Fitzgerald SM, Orchard SG, Trevaks RE, Beilin LJ, Johnston Cl, Ryan J, Radziszewska B, Jelinek M, Malik M, Eaton CB, Brauer D, Cloud G, Wood EM, Mahady SE, Satterfield S, Grimm R, Murray AM; ASPREE
Investigator Group. Effect of aspirin on cardiovascular events and bleeding in the healthy elderly. $N$ Engl J Med 2018; 379:1509-1518.

18. McNeil JJ, Woods RL, Nelson MR, Reid CM, Kirpach B, Wolfe R, Storey E, Shah RC, Lockery JE, Tonkin AM, Newman $A B$, Williamson JD, Margolis KL, Ernst ME, Abhayaratna WP, Stocks N, Fitzgerald SM, Orchard SG, Trevaks RE, Beilin LJ, Donnan GA, Gibbs P, Johnston Cl Ryan J, Radziszewska B, Grimm R, Murray AM; ASPREE Investigator Group. Effect of aspirin on disability-free survival in the healthy elderly. N Engl ] Med 2018; 379:1499-1508.

19. Ridker PM. Should aspirin be used for primary prevention in the post-statin era? N Engl J Med 2018; 379:1572-1574.

20. Oprea AD, Noto CJ, Halaszynski TM. Risk stratification, perioperative and periprocedural management of the patient receiving anticoagulant therapy. J Clin Anesth 2016; 34:586-599.

21. Hart RG, Sharma M, Mundl H, Kasner SE, Bangdiwala SI, Berkowitz SD Swaminathan B, Lavados $\mathrm{P}$, Wang $\mathrm{Y}$, Wang Y, Davalos A, Shamalov N, Mikulik R, Cunha L, Lindgren A, Arauz A, Lang W, Czlonkowska A, Eckstein J, Gagliardi RJ, Amarenco P, Ameriso SF, Tatlisumak T, Veltkamp R, Hankey G), Toni D, Bereczki D, Uchiyama S, Ntaios G, Yoon $B W$, Brouns R, Endres $M$, Muir KW, Bornstein N, Ozturk S, O'Donnell MJ, De Vries Basson MM, Pare G, Pater C, Kirsch B, Sheridan P, Peters G, Weitz JI, Peacock WF, Shoamanesh A, Benavente OR, Joyner C, Themeles E, Connolly SJ; NAVIGATE ESUS Investigators. Rivaroxaban for Stroke Prevention after Embolic Stroke of Undetermined Source. $N$ Engl ] Med 2018; 378:2191-2201.

22. Manchikanti L, Soin A, Mann DP, Bakshi S, Pampati V, Hirsch JA. Reversal of growth of utilization of interventional techniques in managing chronic pain in Medicare population post Affordable Care Act. Pain Physician 2017; 20:551-567.

23. Manchikanti L, Pampati V, Hirsch JA. Retrospective cohort study of usage patterns of epidural injections for spinal pain in the US fee-for-service Medicare population from 2000 to 2014 . BMJ Open 2016; 6:e013042.

24. Manchikanti L, Pampati V, Benyamin RM, Hirsch JA. Cost calculation methodology exacerbates site-of-service differentials by 10 - to 18 -fold for soft tis- 
sue and joint injections in hospital outpatient departments. IPM Reports 2017; 1:183-189.

25. Manchikanti L, Pampati V, Benyamin RM, Hirsch JA. Declining utilization of percutaneous epidural adhesiolysis in Medicare population: Evidence-based or over-regulated? IPM Reports 2018; 2:9-18.

26. Manchikanti MV, Manchikanti L, Kaye AD, Pampati V, Hirsch JA. Usage patterns of sacroiliac joint injections - a comparative evaluation of pre and post Affordable Care Act in Medicare population. IPM Reports 2018; 2:157-166.

27. Manchikanti L, Soin A, Mann DP, Bakshi S, Pampai V, Hirsch JA. Comparative analysis of utilization of epidural procedures in managing chronic pain in the Medicare population: Pre and post Affordable Care Act. Spine (Phila Pa 1976) 2018 July 12 [Epub ahead of print].

28. Manchikanti L, Soin A, Mann DP, Bakshi S, Pampati V, Hirsch JA. Utilization patterns of facet joint interventions in managing spinal pain: A retrospective cohort study in the U.S. fee-for-service Medicare population. BMJ Open 2018; in press.

29. Manchikanti L, Kaye AM, Knezevic NN, McAnally H, Trescot AM, Blank S, Pampati V, Abdi S, Grider JS, Kaye AD, Manchikanti KN, Cordner HJ, Gharibo CG, Harned ME, Albers SL, Atluri S, Aydin SM, Bakshi S, Barkin R, Benyamin RM, Boswell MV, Buenaventura RM, Calodney AK, Cedeno DL, Datta S, Deer TR, Fellows B, Galan V, Grami V, Hansen $\mathrm{H}$, Helm $\mathrm{S}$ 2nd, Justiz R, Koyyalagunta D, Malla Y, Navani A, Nouri K, Pasupuleti R, Sehgal N, Silverman SM, Simopoulos TT, Singh V, Slavin KV, Solanki DR, Staats PS, Vallejo R, Wargo BW, Watanabe A, Hirsch JA. Responsible, safe, and effective prescription of opioids for chronic non-cancer pain: American Society of Interventional Pain Physicians (ASIPP) guidelines. Pain Physician 2017; 20: $\mathrm{S}_{3}-\mathrm{S}_{92}$.

30. Manchikanti L, Sanapati J, Benyamin RM, Atluri S, Kaye AD, Hirsch JA. Reframing the prevention strategies of the opioid crisis: focusing on prescription opioids, fentanyl, and heroin epidemic. Pain Physician 2018; 21:309-326.

31. Manchikanti L, Benyamin RM, Swicegood JR, Falco FJE, Datta S, Pampati $V$, Fellows B, Hirsch JA. Assessment of practice patterns of perioperative management of antiplatelet and anticoagulant therapy in interventional pain management. Pain Physician 2012; 15:E955-E968.

32. Manchikanti L, Malla Y, Wargo BW, Cash KA, McManus CD, Damron KS, Jackson $\mathrm{SD}$, Pampati $\mathrm{V}$, Fellows B. A prospective evaluation of bleeding risk of interventional techniques in chronic pain. Pain Physician 2011; 14:317-329.

33. Smith CC, Schneider B, McCormick ZL, Gill J, Loomba V, Engel AJ, Duszynski B, King W; Standards Division of the Spine Intervention Society. Risks and benefits of ceasing or continuing anticoagulant medication for image-guided procedures for spine pain: A systematic review. Pain Med 2018; 19:438-448.

34. Moeschler SM, Warner NS, Lamer TJ, Bendel MA, Warner MA, Eldrige JS, Mauck WD, Gazelka HM, Kor DJ, Hoelzer BC. Bleeding complications in patients undergoing percutaneous spinal cord stimulator trials and implantations. Pain Med 2016; 17:2076-2081.

35. LaVallee J, Royer R, Smith G. Prevalence of bleeding complications following ultrasound-guided botulinum toxin injections in patients on anticoagulation or antiplatelet therapy. PM R 2017; 9:1217-1224.

36. Breivik $H$, Norum $H$, Fenger-Eriksen C, Alahuhta S, Vigfússon G, Thomas O, Lagerkranser M. Reducing risk of spinal haematoma from spinal and epidural pain procedures. Scand J Pain 2018; 18:129-150.

37. Horlocker TT, Bajwa ZH, Ashraf Z, Khan S, Wilson JL, Sami N, Peeters-Asdourian C, Powers CA, Schroeder DR, Decker PA, Warfield CA. Risk assessment of hemorrhagic complications associated with nonsteroidal antiinflammatory medications in ambulatory pain clinic patients undergoing epidural steroid injection. Anesth Analg 2002; 95:1691-1697.

38. Ahmed SU, Tonidandel W, Trella J, Martin NM, Chang Y. Peri-procedural protocols for interventional pain management techniques: A survey of US pain centers. Pain Physician 2005; 8:181-185.

39. Deer TR, Narouze S, Provenzano DA, Pope JE, Falowski SM, Russo MA, Benzon H, Slavin K, Pilitsis JG, Alo K, Carlson JD, McRoberts P, Lad SP, Arle J, Levy RM, Simpson B, Mekhail N. The Neurostimulation Appropriateness Consensus Committee (NACC): Recommendations on bleeding and coagulation management in neurostimulation devices. Neuromodulation 2017; 20:51-62.

40. Narouze S, Benzon HT, Provenzano D, Buvanendran A, De Andres J, Deer T,
Rauck R, Huntoon MA. Interventional spine and pain procedures in patients on antiplatelet and anticoagulant medications (Second Edition): Guidelines from the American Society of Regional Anesthesia and Pain Medicine, the European Society of Regional Anaesthesia and Pain Therapy, the American Academy of Pain Medicine, the International Neuromodulation Society, the North American Neuromodulation Society, and the World Institute of Pain. Reg Anesth Pain Med 2018; 43:225-262.

41. Petraglia FW 3rd, Farber SH, Gramer R, Verla T, Wang F, Thomas S, Parente B, Lad SP. The incidence of spinal cord injury in implantation of percutaneous and paddle electrodes for spinal cord stimulation. Neuromodulation 2016; 19:85-90.

42. Endres S, Shufelt A, Bogduk N. The risks of continuing or discontinuing anticoagulants for patients undergoing common interventional pain procedures. Pain Med 2017; 18:403-409.

43. Selak V, Kerr A, Poppe K, Wu B, Harwood $M$, Grey C, Jackson R, Wells S. Annual risk of major bleeding among persons without cardiovascular disease not receiving antiplatelet therapy. JAMA 2018; 319:2507-2520.

44. Chen LW, Yin HL. A literature review of antithrombotic and anticoagulating agents on sexual function. Andrologia 2017; 49:10.

45. Sáez-Alcaide LM, Sola-Martín C, Molinero-Mourelle $\mathrm{P}$, Paredes-Rodríguez $\mathrm{V}$, Zarrias-Caballero $C$, Hernández-Vallejo $G$. Dental management in patients with antiplatelet therapy: A systematic review. J Clin Exp Dent 2017; 9:e1044-e1050.

46. Kent TL, Custer PL. Bleeding complications in both anticoagulated and nonanticoagulated surgical patients. Ophthalmic Plast Reconstr Surg 2013; 29:113-117.

47. Veitch AM. Endoscopy in patients on antiplatelet agents and anticoagulants. Curr Treat Options Gastroenterol 2017; 15:256-267.

48. Baron TH, Kamath PS, McBane RD. Management of antithrombotic therapy in patients undergoing invasive procedures. N Engl ] Med 2013; 368:2113-2124.

49. Lucijanic M, Ziga S, Grgurevic I. Comment to: "Management and outcome of gastrointestinal bleeding in patients taking oral anticoagulants or antiplatelet drugs". J Gastroenterol 2017; 52:1075-1076.

50. Goodman BS, House LM, Vallabhaneni S, Mallempati S, Willey MR, Smith MT. Anticoagulant and antiplatelet man- 
agement for spinal procedures: A prospective, descriptive study and interpretation of guidelines. Pain Med 2017; 18:1218-1224.

51. van Helmond N, Day W, Chapman KB. Continuing anti-thrombotic medication during low-to-intermediate risk spinal procedures: A retrospective evaluation. Pain Physician 2017; 20:437-443.

52. Lagerkranser M. Neuraxial blocks and spinal haematoma: Review of 166 case reports published 1994-2015. Part 1: Demographics and risk-factors. Scand J Pain 2017; 15:118-129.

53. Lagerkranser M, Lindquist C. Neuraxial blocks and spinal haematoma: Review of 166 cases published 1994 - 2015. Part 2: diagnosis, treatment, and outcome. Scand J Pain 2017; 15:130-136.

54. Warner NS, Hooten WM, Warner MA, Lamer TJ, Eldrige JS, Gazelka HM, Kor DJ, Hoelzer BC, Mauck WD, Moeschler SM. Bleeding and neurologic complications in 58,000 interventional pain procedures. Reg Anesth Pain Med 2017; 42:782-787.

55. Andrade JG, Macle L, Nattel S, Verma A, Cairns J. Contemporary atrial fibrillation management: A comparison of the current AHA/ACC/HRS, CCS, and ESC guidelines. Can J Cardiol 2017; 33:965-976.

56. Steinberg BA, Washam JB. Appropriate dosing of nonvitamin $\mathrm{K}$ antagonist oral anticoagulants for stroke prevention in atrial fibrillation. Trends Cardiovasc Med 2017; 27:567-572.

57. Erath JW, Hohnloser SH. Anticoagulation in atrial fibrillation: Current evidence and guideline recommendations. Herz 2018; 43:2-10.

58. CDC, NCHS. Underlying Cause of Death 1999-2013 on CDC WONDER Online Database, released 2015. Data are from the Multiple Cause of Death Files, 1999-2013, as compiled from data provided by the 57 vital statistics jurisdictions through the Vital Statistics Cooperative Program.

59. Dieleman JL, Baral R, Birger M, Bui AL, Bulchis A, Chapin A, Hamavid H, Horst C, Johnson EK, Joseph J, Lavado R, Lomsadze L, Reynolds A, Squires E, Campbell $M$, DeCenso B, Dicker D, Flaxman $A D$, Gabert R, Highfill T, Naghavi $M$, Nightingale N, Templin T, Tobias MI, Vos T, Murray CJ. US spending on personal health care and public health, 1996-2013. JAMA 2016; 316:2627-2646.

6o. Dieleman JL, Squires E, Bui AL, Campbell $M$, Chapin A, Hamavid $H$, Horst C, Li Z, Matyasz T, Reynolds A, Sadat
N, Schneider MT, Murray CJL. Factors associated with increase in US health care spending, 1996-2013. JAMA 2017; 318:1668-1678.

61. Centers for Disease Control and Prevention. 2018 Annual Surveillance Report of Drug-Related Risks and Outcomes United States. Surveillance Special Report. Centers for Disease Control and Prevention, U.S. Department of Health and Human Services. Published August 31, 2018.

/www.cdc.gov/drugoverdose/pdf/ pubs/2018-cdc-drug-surveillance-report.pdf

62. Hoy D, Brooks $P$, Blyth F, Buchbinder R. The epidemiology of low back pain. Best Pract Res Clin Rheumatol 2010; 24:769-781.

63. Hoy DG, Protani M, De R, Buchbinder R. The epidemiology of neck pain. Best Pract Res Clin Rheumatol 2010; 24:783-792.

64. Hoy DG, Bain C, Williams G, March L, Brooks P, Blyth F, Woolf A, Vos T, Buchbinder R. A systematic review of the global prevalence of low back pain. Arthritis Rheum 2012; 64:2028-2037.

65. Manchikanti L, Atluri S, Candido KD, Boswell MV, Simopoulos TT, Grider JS, Falco FJE, Hirsch JA. ZohydroTM approval by Food and Drug Administration: Controversial or frightening? Pain Physician 2014; 17: E437-E450.

66. Navani A, Manchikanti L, Albers SL, Latchaw RE, Sanapati J, Kaye AD, Atluri S, Jordan S, Gupta A, Cedeno D, Vallejo A, Fellows B, Knezevic NN, Pappolla M, Diwan S, Trescot AM, Soin A, Kaye AM, Aydin SM, Calodney AK, Candido KD, Bakshi S, Benyamin RM, Vallejo R, Watanabe A, Beall D, Stitik TP, Foye PM, Helander EM, Hirsch JA. Responsible, safe, and effective use of biologics in management of low back pain: American Society of Interventional Pain Physicians' guidelines. Pain Physician 2018; in press.

67. Becattini C, Franco L, Agnelli G. Risk of death in patients with major bleedings while on treatment with oral anticoagulants. Int J Cardiol 2017; 235:200.

68. Melmed KR, Lyden P, Gellada N, Moheet $A$. Intracerebral hemorrhagic expansion occurs in patients using nonvitamin $\mathrm{K}$ Antagonist oral anticoagulants comparable with patients using warfarin. J Stroke Cerebrovasc Dis 2017; 26:1874-1882.

69. Biondi-Zoccai GG, Lotrionte M, Agostoni P, Abbate A, Fusaro M, Burzotta F,
Testa L, Sheiban I, Sangiorgi G. A systematic review and meta-analysis on the hazards of discontinuing or not adhering to aspirin among 50,279 patients at risk for coronary artery disease. Eur Heart ] 2006; 27:2667-2674.

70. Gurbel PA, Bliden KP, Hiatt BL, O'Connor CM. Clopidogrel for coronary stenting: Response variability, drug resistance, and the effect of pretreatment platelet reactivity. Circulation 2003; 107:2908-2913.

71. Cerrato E, D'Ascenzo F, Biondi-Zoccai GG, Abbate A. Dual antiplatelet therapy after drug-eluting stent implantation: when is "enough" enough? ] Cardiovasc Pharmacol 2014; 64:38-40.

72. Zullo A, Hassan C, Radaelli F. Gastrointestinal endoscopy in patients on anticoagulant therapy and antiplatelet agents. Ann Gastroenterol 2017; 30:7-14.

73. Saia F. Surgery after drug-eluting stent implantation: it's not all doom and gloom! J Thorac Dis 2017; 9:E373-E377.

74. Huynh K. Pharmacotherapy: Aspirin discontinuation increases risk of cardiovascular events. Nat Rev Cardiol 2017; 14:696-697.

75. Lotrionte M, Biondi-Zoccai GG. The hazards of discontinuing acetylsalicylic acid therapy in those at risk of coronary artery disease. Curr Opin Cardiol 2008; 23:487-493.

76. Luni FK, Riaz H, Khan AR, Riaz T, Husnain M, Riaz IB, Khan MS, Taleb M, Kanjwal Y, Cooper CJ, Khuder SA. Clinical outcomes associated with per-operative discontinuation of aspirin in patients with coronary artery disease: A systematic review and meta-analysis. Catheter Cardiovasc Interv 2017; 89:1168-1175.

77. Hastings S, Myles PS, Mcllroy DR. Aspirin and coronary artery surgery: An updated meta-analysis. Br J Anaesth 2016; 116:716-717.

78. Ho PM, Peterson ED, Wang L, Magid DJ, Fihn SD, Larsen GC, Jesse RA, Rumsfeld $J S$. Incidence of death and acute myocardial infarction associated with stopping clopidogrel after acute coronary syndrome. JAMA 2008; 299:532-539. Erratum in: JAMA 2008; 299:2390.

79. Marso SP, Amin AP, House JA, Kennedy KF, Spertus JA, Rao SV, Cohen DJ, Messenger JC, Rumsfeld JS; National Cardiovascular Data Registry. Association between use of bleeding avoidance strategies and risk of periprocedural bleeding among patients undergoing percutaneous coronary intervention. JAMA 2010; 303:2156-2164. 
8o. Sprigg N, Gray LJ, England T, Willmot MR, Zhao L, Sare GM, Bath PM. A randomised controlled trial of triple antiplatelet therapy (aspirin, clopidogrel and dipyridamole) in the secondary prevention of stroke: Safety, tolerability and feasibility. PLoS One 2008; 3:e2852.

81. Walker CW, Dawley CA, Fletcher SF. Aspirin combined with clopidogrel (Plavix) decreases cardiovascular events in patients with acute coronary syndrome. Am Fam Physician 2007; 76:1643-1645.

82. Manchikanti L, Abdi S, Atluri S, Benyamin RM, Boswell MV, Buenaventura RM, Bryce DA, Burks PA, Caraway DL, Calodney AK, Cash KA, Christo PJ, Cohen SP, Colson J, Conn A, Cordner HJ, Coubarous S, Datta S, Deer TR, Diwan SA, Falco FJE, Fellows B, Geffert SC, Grider JS, Gupta S, Hameed H, Hameed $M$, Hansen $H$, Helm II S, Janata JW, Justiz R, Kaye AD, Lee $M$, Manchikanti KN, McManus CD, Onyewu O, Parr AT, Patel VB, Racz GB, Sehgal N, Sharma $M$, Simopoulos TT, Singh V, Smith HS, Snook LT, Swicegood J, Vallejo R, Ward SP, Wargo BW, Zhu J, Hirsch JA. An update of comprehensive evidence-based guidelines for interventional techniques of chronic spinal pain: Part II: Guidance and recommendations. Pain Physician 2013; 16:S49-S283.

83. Chou R, Hashimoto R, Friedly J, Fu R, Dana T, Sullivan S, Bougatsos C, Jarvik J. Pain Management Injection Therapies for Low Back Pain. Technology Assessment Report ESIBo813. (Prepared by the Pacific Northwest Evidence-based Practice Center under Contract No. HHSA 290-2012-00014-I.) Rockville, MD: Agency for Healthcare Research and Quality; July 10, 2015.

84. Boswell MV, Manchikanti L. Appropriate design and methodologic quality assessment, clinically relevant outcomes are essential to determine the role of epidural corticosteroid injections. Commentary RE: Chou R, Hashimoto R, Friedly J, Fu R, Bougatsos C, Dana $\mathrm{T}$, Sullivan SD, Jarvik J. Epidural corticosteroid injections for radiculopathy and spinal stenosis: A systematic review and meta-analysis. Ann Intern Med 2015; 163:373-381. Evid Based Med 2016; 21:89.

85. Simopoulos TT, Manchikanti L, Gupta S, Aydin SM, Kim CH, Solanki D, Nampiaparampil DE, Singh V, Staats PS, Hirsch JA. Systematic review of the diagnostic accuracy and therapeutic effectiveness of sacroiliac joint interventions. Pain Physician 2015; 18:E713-E756.

86. Grider JS, Manchikanti L, Carayan- nopoulos A, Sharma ML, Balog CC, Harned ME, Grami V, Justiz R, Nouri $\mathrm{KH}$, Hayek SM, Vallejo R, Christo PJ. Effectiveness of spinal cord stimulation in chronic spinal pain: A systematic review. Pain Physician 2016; 19: $\mathrm{E}_{33}-\mathrm{E}_{54}$

87. Manchikanti L, Hirsch JA, Falco FJ, Boswell MV. Management of lumbar zygapophysial (facet) joint pain. World J Orthop 2016; 7:315-337.

88. Manchikanti L, Hirsch JA, Kaye AD, Boswell MV. Cervical zygapophysial (facet) joint pain: Effectiveness of interventional management strategies. Postgrad Med 2016; 128:54-68.

89. Helm II S, Racz GB, Gerdesmeyer L, Justiz L, Hayek SM, Kaplan ED, El Terany MA, Knezevic NN. Percutaneous and endoscopic adhesiolysis in managing low back and lower extremity pain: A systematic review and meta-analysis. Pain Physician 2016; 19:E245-E282.

90. Manchikanti L, Manchikanti KN, Gharibo CG, Kaye AD. Efficacy of percutaneous adhesiolysis in the treatment of lumbar post surgery syndrome. Anesth Pain Med 2016; 6:e26172.

91. Manchikanti L, Kaye AD, Manchikanti KN, Boswell MV, Pampati V, Hirsch JA. Efficacy of epidural injections in the treatment of lumbar central spinal stenosis: A systematic review. Anesth Pain Med 2015; 5:e23139.

92. Helm II S, Simopoulos TT, Stojanovic MP, Abdi S, El Terany MA. Effectiveness of thermal annular procedures in treating discogenic low back pain. Pain Physician 2017; 20:447-470.

93. Manchikanti L, Staats PS, Nampiaparampil DE, Hirsch JA. What is the role of epidural injections in the treatment of lumbar discogenic pain: A systematic review of comparative analysis with fusion and disc arthroplasty. Korean J Pain 2015; 28:75-87.

94. Manchikanti L, Singh V, Pampati $\mathrm{V}$, Falco FJE, Hirsch JA. Comparison of the efficacy of caudal, interlaminar, and transforaminal epidural injections in managing lumbar disc herniation: Is one method superior to the other? Korean J Pain 2015; 28:11-21.

95. Manchikanti L, Pampati V, Benyamin RM, Boswell MV. Analysis of efficacy differences between caudal and lumbar interlaminar epidural injections in chronic lumbar axial discogenic pain: Local anesthetic alone vs. local combined with steroids. Int ] Med Sci 2015; 12:214-222.

96. Manchikanti L, Knezevic NN, Boswell MV, Kaye AD, Hirsch JA. Epidural injec- tions for lumbar radiculopathy and spinal stenosis: A comparative systematic review and meta-analysis. Pain Physician 2016; E365-E410.

97. Manchikanti L, Falco FJE, Pampati V, Cash KA, Benyamin RM, Hirsch JA. Cost utility analysis of caudal epidural injections in the treatment of lumbar disc herniation, axial or discogenic low back pain, central spinal stenosis, and post lumbar surgery syndrome. Pain Physician 2013; 16:E129-E143.

98. Manchikanti L, Pampati V, Benyamin RM, Hirsch JA. Cost utility analysis of lumbar interlaminar epidural injections in the treatment of lumbar disc herniation, central spinal stenosis, and axial or discogenic low back pain. Pain Physician 2017; 20:219-228.

99. Manchikanti L, Pampati V, Kaye AD, Hirsch JA. Therapeutic lumbar facet joint nerve blocks in the treatment of chronic low back pain: Cost utility analysis based on a randomized controlled trial. Korean J Pain 2018; 31:27-38.

100. Manchikanti L, Pampati V, Kaye AD, Hirsch JA. Cost utility analysis of cervical therapeutic medial branch blocks in managing chronic neck pain. Int J Med Sci 2017; 14:1307-1316.

101. Manchikanti L, Malla Y, Cash KA, Pampati V, Hirsch JA. Comparison of effectiveness for fluoroscopic cervical interlaminar epidural injections with or without steroid in cervical post-surgery syndrome. Korean J Pain 2018; 31:277-288.

102. Taylor RS, Ryan J, O'Donnell R, Eldabe S, Kumar K, North RB. The cost-effectiveness of spinal cord stimulation in the treatment of failed back surgery syndrome. Clin J Pain 2010; 26:463-469.

103. Kumar K, Rizvi S. Cost-effectiveness of spinal cord stimulation therapy in management of chronic pain. Pain Med 2013; 14:1631-1649.

104. Taylor RS, Van Buyten JP, Buchser E. Spinal cord stimulation for complex regional pain syndrome: A systematic review of the clinical and cost-effectiveness literature and assessment of prognostic factors. Eur J Pain 2006; 10:91-101.

105. Bala MM, Riemsma RP, Nixon J, Kleijnen J. Systematic review of the (cost-) effectiveness of spinal cord stimulation for people with failed back surgery syndrome. Clin J Pain 2008; 24:757-758.

106. Manchikanti L, Helm S 2nd, Benyamin RM, Hirsch JA. A critical analysis of Obamacare: Affordable care or insurance for many and coverage for few? Pain Physician 2017; 20:111-138. 
107. Hirsch JA, Leslie-Mazwi TM, Nicola GN, Bhargavan-Chatfield $M$, Seidenwurm DJ, Silva E, Manchikanti L. PQRS and the MACRA:Value-based payments have moved from concept to reality. AJNR Am J Neuroradiol 2016; 37:2195-2200.

108. Hirsch JA, Rosenkrantz AB, Ansari SA, Manchikanti L, Nicola GN. MACRA 2.0: Are you ready for MIPS? J Neurointerv Surg 2017; 9:714-716.

109. Meng H, Fei Q, Wang B, Yang Y, Li D, Li J, Su N. Epidural injections with or without steroids in managing chronic low back pain secondary to lumbar spinal stenosis: A meta-analysis of 13 randomized controlled trials. Drug Des Devel Ther 2015; 9:4657-4667.

110. Zhai J, Zhang L, Li M, Tian Y, Zheng W, Chen J, Huang T, Li X, Tian Z. Epidural injection with or without steroid in managing chronic low back and lower extremity pain: A meta-analysis of ten randomized controlled trials. Int J Clin Exp Med 2015; 8:8304-8316.

111. Zhai J, Zhang L, Li M, Tian Z, Tian Y, Zheng W, Chen J, Huang T, Li X. Epidural injection with or without steroid in managing chronic low-back and lower extremity pain: A meta-analysis of 10 randomized controlled trials. Am J Ther 2017; 24:e259-e269.

112. Liu K, Liu P, Liu R, Wu X, Cai M. Steroid for epidural injection in spinal stenosis: a systematic review and meta-analysis. Drug Des Devel Ther 2015; 9:707-716.

113. Lee JH, Shin KS, Park SJ, Lee GJ, Lee CH, Kim DH, Kim DH, Yang HS. Comparison of clinical efficacy between transforaminal and interlaminar epidural injections in lumbosacral disc herniation: A systematic review and meta-analysis. Pain Physician 2018; 21:433-448.

114. Lee JH, Kim DH, Kim, DH, Shin KS Park SJ, Lee GJ, Lee CH, Yang HS. Comparison of clinical efficacy of epidural injection with or without steroid in lumbosacral disc herniation: A systematic review and meta-analysis. Pain Physician 2018; 21:449-468.

115. Manchikanti L, Benyamin RM, Falco FJ, Kaye AD, Hirsch JA. Do epidural injections provide short- and long-term relief for lumbar disc herniation? A systematic review. Clin Orthop Relat Res 2015; 473:1940-1956.

116. Manchikanti L, Nampiaparampil DE, Manchikanti KN, Falco FJE, Singh V, Benyamin RM, Kaye AD, Sehgal N, Soin A, Simopoulos TT, Bakshi S, Gharibo CG, Gilligan CJ, Hirsch JA. Comparison of the efficacy of saline, local anesthetics, and steroids in epidural and facet joint injections for the management of spinal pain: A systematic review of randomized controlled trials. Surg Neurol Int 2015; 6:S194-S235.

117. Hunter CW, Stovall B, Chen G, Carlson J, Levy R. Anatomy, pathophysiology and interventional therapies for chronic pelvic pain: A review. Pain Physician 2018; 21:147-167.

118. Shen J, Xu S, Xu S, Ye S, Hao J. Fusion or not for degenerative lumbar spinal stenosis: A meta-analysis and systematic review. Pain Physician 2018; 21:1-8.

119. Wu JJ, Chen HZ, Zheng C. Transforaminal percutaneous endoscopic discectomy and foraminoplasty after lumbar spinal fusion surgery. Pain Physician 2017; 20:E647-E651.

120. Rosian K, Hawlik K, Piso B. Efficacy assessment of radiofrequency ablation as a palliative pain treatment in patients with painful metastatic spinal lesions: A systematic review. Pain Physician 2018; 21:E467-E476.

121. Xiang GH, Tong MJ, Lou C, Zhu SP, Guo WJ, Ke CR. The role of unilateral balloon kyphoplasty for the treatment of patients with OVCFS: A systematic review and meta-analysis. Pain Physician 2018; 21:209-218.

122. Bellini $M$, Barbieri $M$. Coagulation management in epidural steroid injection. Anaesthesiol Intensive Ther 2014; 46:195-199.

123. Gogarten W, Van Aken H, Buttner J, Riess $H$, Wulf $H$, Buerkle $H$. Neuraxial blockade and thromboembolism prophylaxis/antithrombotic therapy: Revised recommendations of the German Society of Anaesthesiology and Intensive Care. Anaesth Intensivmed 2003; 44:218-230.

124. Llau JV, de Andrés J, Gomar C, Gómez A, Hidalgo F, Sahagún J, Torres LM. Drugs that alter hemostasis and regional anesthetic techniques: Safety guidelines. Consensus Conference. Rev Esp Anestesiol Reanim 2001; 48:270-278.

125. Bugada D, Massimo A, Nicola Z, Antonio B, Battista B, Paolo G. Regional anesthesia and anticoagulant drugs: A survey of current Italian practice. Eur J Pain Suppl 2011; 5:335-343.

126. Gogarten W, Buerkle $\mathrm{H}$, Van Aken H. The use of concomitant antiplatelet drugs during neuraxial anethesia is contraindicated in Germany. Reg Anesth Pain Med 2003; 28:585-586; author reply 586.

127. Llau Pitarch JV, De Andrés Ibáñez J, Go- mar Sancho C, Gómez Luque Z, Hidalgo Martínez F, Torres Morera LM. Hemostasis-altering drugs and techniques for regional anesthesia and analgesia: Safety recommendations. Rev Esp Anestesiol Reanim 2005; 52:248-250.

128. Kozek-Langenecker SA, Fries D, Gütl $M$, Hofmann $N$, Innerhofer $P$, Kneifl W, Neuner L, Perger P, Pernerstorfer T, Pfanner G, Schöchl H; Task Force on Perioperative Coagulation of the Austrian Society for Anesthesiology and Intensive Care Medicine. Locoregional anesthesia and coagulation inhibitors. Recommendations of the Task Force on Perioperative Coagulation of the Austrian Society for Anesthesiology and Intensive Care Medicine. Anaesthesist 2005; 54:476-484

129. Gallice $M$, Rouberol $F$, Albaledejo $P$, Brillat Zaratzian E, Palombi K, Aptel F, Romanet JP, Chiquet $C$. Managing antithrombotic therapy in vitreoretinal surgery. J Fr Ophtalmol 2015; 38:61-73.

130. Benyamin RM, Vallejo R, Wang V, Kumar N, Cedeno DL, Tamrazi A. Acute epidural hematoma formation in cervical spine after interlaminar epidural steroid injection despite discontinuation of clopidogrel. Reg Anesth Pain Med 2016; 41:398-401.

131. Buvanendran A, Young AC. Spinal epidural hematoma after spinal cord stimulator trial lead placement in a patient taking aspirin. Reg Anesth Pain Med 2014; 39:70-72.

132. Chien GC, McCormick Z, Araujo M, Candido KD. The potential contributing effect of ketorolac and fluoxetine to a spinal epidural hematoma following a cervical interlaminar epidural steroid injection: A case report and narrative review. Pain Physician 2014; 17:E385-395.

133. Giberson CE, Barbosa J, Brooks ES, McGlothlen GL, Grigsby EJ, Kohut JJ, Wolbers LL, Poree LR. Epidural hematomas after removal of percutaneous spinal cord stimulator trial leads: Two case reports. Reg Anesth Pain Med 2014; 39:73-77.

134. Page J, Moisi M, Oskouian RJ. Lumbar epidural hematoma following interlaminar fluoroscopically guided epidural steroid injection. Reg Anesth Pain Med 2016; 41:402-404.

135. Swicegood J, Manchikanti L, Benyamin $\mathrm{R}$, Hirsch J. A report of acute thoracic epidural hematoma after interlaminar epidural injection. IPM Reports 2017; 1:33-38.

136. Swicegood J, Manchikanti L, Benyamin 
R, Hirsch J. Two cases of acute epidural hematoma formation after cervical interlaminar epidural steroid injections. IPM Reports 2017; 1:27-32.

137. Jenkie E, Benyamin R, Manchikanti L. Fish oil as a potential contributor to epidural hematoma following cervical epidural steroid injection: A case report and focused literature review. IPM Reports 2017; 1:19-26.

138. Manchikanti L, Malla Y, Benyamin R, Hirsch J. Prevalence of epidural hematoma following cervical epidural injections in interventional pain management settings: Literature review with two case reports. IPM Reports 2017; 1:11-17.

139. Kim SH, Han YJ, Kim YH, Lee JM, Kim YM, Park HJ. Spontaneous absorption of a lumbar epidural hematoma after interlaminar epidural steroid injection in a patient with spinal stenosis: Close observation as a treatment strategy. Chin Med J (Engl) 2018; 131:117-118.

140. Manchikanti L, Gruber TJ, Prabhakar H, Hirsch JA. Acute epidural hematoma following a cervical epidural injection in a patient without bleeding risk. IPM Reports 2018; 2:119-126.

141. Lam CM, Monroe BR, Novosat T. Spontaneous resolution of presumed acute epidural hematoma formation after lumbar epidural steroid injection. IPM Reports 2017; 1:157-161.

142. Candido KD. Epidural hematoma formation following neuraxial interventional pain management procedures. Have we even begun to comprehend the mechanisms and risk factors? IPM Reports 2017; 1:7-10.

143. Sanders RA, Bendel MA, Moeschler SM, Mauck WD. Epidural hematoma following interlaminar epidural injection in patient taking aspirin. Reg Anesth Pain Med 2018; 43:310-312.

144. Berrigan WA, Whitehair C, Zorowitz R. Acute spinal epidural hematoma as a complication of dry needling: A case report. PM R 2018 Jul 21 [Epub ahead of print].

145. Cameron CM, Scott DA, McDonald WM, Davies MJ. A review of neuraxial epidural morbidity: Experience of more than 8,000 cases at a single teaching hospital. Anesthesiology 2007; 106:997-1002.

146. Noori S, Laufer I, Gulati A. Acute epidural hematoma occurring after removal of percutaneous spinal cord stimulator trial leads in a cancer patient with chronic thrombocytopenia: A case report. IPM Reports 2018; 2:27-33.
147. Warner NS, Bendel MA, Warner MA, Strand JJ, Gazelka HM, Hoelzer BC, Mauck WD, Lamer TJ, Kor DJ, Moeschler SM. Bleeding complications in patients undergoing intrathecal drug delivery system implantation. Pain Med 2017; 18:2422-2427.

148. Caputo AM, Gottfried ON, Nimjee SM, Brown CR, Michael KW, Richardson WJ. Spinal epidural hematoma following epidural steroid injection in a patient treated with dabigatran: A case report. JBJS Case Connect 2013; 3:e64.

149. Warner NS, Moeschler SM, Warner MA, Hoelzer BC, Eldrige JS, Bendel MA, Mauck WD, Watson JC, Gazelka HM, Lamer TJ, Kor DJ, Hooten WM. Bleeding complications in patients undergoing celiac plexus block. Reg Anesth Pain Med 2016; 41:488-493.

150. Lagerkranser $M$, Johnsson $H$, Ljungström KG. Management of thrombocyte inhibitors prior to surgery. Too early withdrawal can result in severe risks for the patient. Lakartidningen 2008; 105:2188-2189.

151. Gould MK, Garcia DA, Wren SM, Karanicolas PJ, Arcelus JI, Heit JA, Samama CM. Prevention of VTE in nonorthopedic surgical patients: Antithrombotic therapy and prevention of thrombosis, 9th ed: American College of Chest Physicians evidence-based clinical practice guidelines. Chest 2012; 141:e227S-e277S.

152. Falck-Ytter Y, Francis CW, Johanson NA, Curley C, Dahl OE, Schulman S, Ortel TL, Pauker SG, Colwell CW Jr. Prevention of VTE in orthopedic surgery patients: antithrombotic therapy and prevention of thrombosis, gth ed: American College of Chest Physicians evidencebased clinical practice guidelines. Chest 2012; 141:e278S-e325S.

153. ACCP-NHLBI national conference on antithrombotic therapy. American College of Chest Physicians and the $\mathrm{Na}$ tional Heart, Lung and Blood Institute. Chest 1986; 89:1S-106S.

154. Guyatt GH, Akl EA, Crowther M, Schünemann HJ, Gutterman DD, Lewis SZ. Introduction to the ninth edition: Antithrombotic therapy and prevention of thrombosis, gth ed: American College of Chest Physicians evidence-based clinical practice guidelines. Chest 2012; 141:48S-52S.

155. Eikelboom JW, Hirsh J, Spencer FA, Baglin TP, Weitz JI. Antiplatelet drugs: Antithrombotic therapy and prevention of thrombosis, 9th ed: American College of Chest Physicians evidence-based clinical practice guidelines. Chest 2012; 141:e8gS-e119S.

156. The National Uniform Claims Committee. Specialty Designation for Interventional Pain Management- o9.

www.cms.hhs.gov/transmittals/Downloads/r177gb3.pdf

157. Medicare Payment Advisory Commission. Report to the Congress: Paying for interventional pain services in ambulatory settings. Washington, DC: MedPAC. December. 2001.

www.medpac.gov/documents/reports/december-2001-report-to-thecongress-paying-for-interventionalpain-services-in-ambulatory-settings. pdf?sfursn=o

158. Graham R, Mancher M, Wolman DM, Greenfield S, Steinberg E (eds); Committee on Standards for Systematic Reviews of Comparative Effectiveness Research; Institute of Medicine. Clinical Practice Guidelines We Can Trust. The National Academies Press, Washington, DC, 2011.

159. National Guideline Clearinghouse Extent Adherence to Trustworthy Standards (NEATS) instrument.

www.ncbi.nlm.nih.gov/pubmedhealth/ PMHoo79458/.

160. Harris RP, Helfand M, Woolf SH, Lohr KN, Mulrow CD, Teutsch SM, Atkins D; Methods Work Group, Third US Preventive Services Task Force. Current methods of the US Preventive Services Task Force. Am J Prevent Med 2001; 20:21-35.

161. Manchikanti L, Falco FJE, Benyamin R M, Kaye AD, Boswell MV, Hirsch JA. A modified approach to grading of evidence. Pain Physician 2014; 17:E319-E325.

162. Liberati A, Altman DG, TetzlaffJ, Mulrow C, Gøtzsche PC, loannidis JP, Clarke M, Devereaux PJ, Kleijnen J, Moher D. The PRISMA statement for reporting systematic reviews and meta-analyses of studies that evaluate health care interventions: Explanation and elaboration. Ann Intern Med 2009; 151:W65-W94.

163. Shea BJ, Reeves BC, Wells G, Thuku M, Hamel C, Moran J, Moher D, Tugwell $P$, Welch V, Kristjansson E, Henry DA. AMSTAR 2: A critical appraisal tool for systematic reviews that include randomised or non-randomised studies of healthcare interventions, or both. BM] 2017; 358:j4008.

164. Stroup DF, Berlin JA, Morton SC, Olkin I, Williamson GD, Rennie D, Moher D, Becker BJ, Sipe TA, Thacker SB. Metaanalysis of observational studies in epidemiology: A proposal for reporting. 
Meta-analysis of Observational Studies in (MOOSE) group. JAMA 2000; 283:2008-2012.

165. Furlan $A D$, Malmivaara $A$, Chou $R, M a-$ her CG, Deyo RA, Schoene M, Bronfort G, van Tulder MW; Editorial Board of the Cochrane Back, Neck Group. 2015 Updated Method Guideline for Systematic Reviews in the Cochrane Back and Neck Group. Spine (Phila Pa 1976) 2015; 40:1660-1673.

166. Manchikanti L, Hirsch JA, Cohen SP, Heavner JE, Falco FJE, Diwan S, Boswell MV, Candido KD, Onyewu CO, Zhu J, Sehgal N, Kaye AD, Benyamin RM, Helm $S$ and, Singh V, Datta S, Abdi S, Christo PJ, Hameed H, Hameed M, Vallejo R, Pampati V, Racz GB, Raj PP. Assessment of methodologic quality of randomized trials of interventional techniques: Development of an interventional pain management specific instrument. Pain Physician 2014; 17:E263-E290.

167. Manchikanti L, Hirsch JA, Heavner JE, Cohen SP, Benyamin RM, Sehgal N, Falco FJE, Vallejo R, Onyewu O, Zhu J, Kaye AD, Boswell MV, Helm II S, Candido KD, Diwan S, Simopoulos TT, Singh V, Pampati V, Racz GB, Raj PP. Development of an interventional pain management specific instrument for methodologic quality assessment of nonrandomized studies of interventional techniques. Pain Physician 2014; 17:E291-E317.

168. Sanapati J, Manchikanti L, Atluri S, Jordan S, Albers SL, Pappolla MA, Kaye AD, Candido KD, Pampati V, Hirsch JA. Do regenerative medicine therapies provide long-term relief in chronic low back pain: A systematic review and metaanalysis. Pain Physician 2018; 21:515-540.

169. Jeong H, Yim HW, Cho YS, Kim Yl, Jeong SN, Kim HB, Oh IH. Efficacy and safety of stem cell therapies for patients with stroke: A systematic review and single arm meta-analysis. Int J Stem Cells 2014; 7:63-69.

170. Huedo-Medina TB, Sánchez-Meca J, Marín-Martínez F, Botella J. Assessing heterogeneity in meta-analysis: Q statistic or 12 index? Psychol Methods 2006; 11:193-206.

171. Breivik H, Bang U, Jalonen J, Vigfússon G, Alahuhta S, Lagerkranser M. Nordic guidelines for neuraxial blocks in disturbed haemostasis from the Scandinavian Society of Anaesthesiology and Intensive Care Medicine. Acta Anaesthesiol Scand 2010; 54:16-41.

172. Gogarten W, Vandermeulen E, Van Aken
H, Kozek S, Llau JV, Samama CM; European Society of Anaesthesiology. Regional anaesthesia and antithrombotic agents: Recommendations of the European Society of Anaesthesiology. Eur J Anaesthesiol 2010; 27:999-1015.

173. Vandermeulen E. Regional anaesthesia and anticoagulation. Best Pract Res Clin Anaesthesiol 2010; 24:121-131.

174. Horlocker TT, Vandermeuelen E, Kopp SL, Gogarten W, Leffert LR, Benzon HT. Regional Anesthesia in the patient receiving antithrombotic or thrombolytic therapy: American Society of Regional Anesthesia and Pain Medicine EvidenceBased Guidelines (Fourth Edition). Reg Anesth Pain Med 2018; 43:263-309.

175. Schmidt A, Nolte H. Subdural and epidural hematomas following epidural anesthesia. A literature review. Anaesthesist 1992; 41:276-284.

176. Vandermeulen $\mathrm{E}$, van Aken $\mathrm{H}$, Vermylen $J$. Anticoagulants and spinal epidural anesthesia. Anesth Analg 1994; 79:1165-1177.

177. Wulf H. Epidural anaesthesia and spinal haematoma. Can J Anaesth 1996; 43:1260-1271.

178. Kumar V, Turakhia PB, Wunnava MS. Pulmonary embolism during dorsal column stimulator (DCS) trial. Reg Anesth Pain Med 2013; 38 (abstract only).

179. Linn AJ, Desilva C, Peeters-Asdourian C. Thromboembolic stroke: A rare complication associated with peri-procedural management of an epidural steroid injection. Pain Physician 2009; 12:159-162.

180. Desai MJ, Dua S. Perineural hematoma following lumbar transforaminal steroid injection causing acute-on-chronic lumbar radiculopathy: A case report. Pain Pract 2014; 14:271-277.

181. Shanthanna H, Park J. Acute epidural haematoma following epidural steroid injection in a patient with spinal stenosis. Anaesthesia 2011; 66:837-839.

182. Williams KN, Jackowski A, Evans PJ. Epidural haematoma requiring surgical decompression following repeated cervical epidural steroid injections for chronic pain. Pain 1990; 42:197-199.

183. Ghaly RF. Recovery after high-dose methylprednisolone and delayed evacuation: A case of spinal epidural hematoma. J Neurosurg Anesthesiol 2001; 13:323-328.

184. Weller RS, Gerancher JC, Crews JC, Wade KL. Extensive retroperitoneal hematoma without neurologic deficit in two patients who underwent lumbar plexus block and were later anticoagulated. Anesthesiology 2003; 98:581-585.

185. Stoll A, Sanchez M. Epidural hematoma after epidural block: Implications for its use in pain management. Surg Neurol 2002; 57:235-240.

186. Swerdlow M. Medico-legal aspects of complications following pain relieving blocks. Pain 1982; 13:321-331.

187. Chiravuri S, Wasserman R, Chawla A, Haider N. Subdural hematoma following spinal cord stimulator implant. Pain Physician 2008; 11:97-101.

188. Xu R, Bydon M, Gokaslan ZL, Wolinsky JP, Witham TF, Bydon A. Epidural steroid injection resulting in epidural hematoma in a patient despite strict adherence to anticoagulation guidelines. J Neurosurg Spine 2009; 11:358-364.

189. Ain RJ, Vance MB. Epidural hematoma after epidural steroid injection in a patient withholding enoxaparin per guidelines. Anesthesiology 2005; 102:701-703.

190. Lee JH, Lee H, Jo DJ. An acute cervical epidural hematoma as a complication of dry needling. Spine (Phila Pa 1976) 2011; 36:E891-E893.

191. Reitman CA, Watters W 3rd. Subdural hematoma after cervical epidural steroid injection. Spine (Phila Pa 1976) 2002; 27:E174-E176.

192. Eftekhar B, Ketabchi E, Ghodsi M, Esmaeeli B. Lumbar epidural hematoma due to lumbar acupunctures. Neurol India 2005; 53:245-246.

193. Ozdemir O, Calisaneller T, Yildirim E, Altinors N. Acute intracranial subdural hematoma after epidural steroid injection: A case report.] Manipulative Physiol Ther 2007; 30:536-538.

194. Chen JC, Chen Y, Lin SM, Yang HJ, Su $\mathrm{CF}$, Tseng $\mathrm{SH}$. Acute spinal epidural hematoma after acupuncture. J Trauma 2006; 60:414-416.

195. Lee JY, Nassr A, Ponnappan RK. Epidural hematoma causing paraplegia after a fluoroscopically guided cervical nerveroot injection. A case report. J Bone Joint Surg Am 2007; 89:2037-2039.

196. Bose B. Quadriparesis following cervical epidural steroid injections: Case report and review of the literature. Spine J 2005; 5:558-563.

197. Domenicucci M, Marruzzo D, Pesce A, Raco A, Missori P. Acute spinal epidural hematoma after acupuncture: Personal case and literature review. World Neurosurg 2017; 102:695.e11-695.e14.

198. Fitzgibbon DR, Posner KL, Domino KB, 
Caplan RA, Lee LA, Cheney FW; American Society of Anesthesiologists. Chronic pain management: American Society of Anesthesiologists Closed Claims Project. Anesthesiology 2004; 100:98-105.

199. Maier C, Gleim M, Weiss T, Stachetzki U, Nicolas V, Zenz M. Severe bleeding following lumbar sympathetic blockade in two patients under medication with irreversible platelet aggregation inhibitors. Anesthesiology 2002; 97:740-743.

200. Benzon HT, Wong HY, Siddiqui T, Ondra S. Caution in performing epidural injections in patients on several antiplatelet drugs. Anesthesiology 1999; 91:1558-1559.

201. Keane JR, Ahmadi J, Gruen P. Spinal epidural hematoma with subarachnoid hemorrhage caused by acupuncture. AJNR Am J Neuroradiol 1993; 14:365-366.

202. Choi JJ, Chang YJ, Jung WS, Lee KC, Kim $\mathrm{JH}$, Jo YY. Discordant lumbar epidural hematoma after caudal steroid injection: A case report (CARE-compliant). Medicine (Baltimore) 2017; 96:e7127.

203. Kim M, Park KS. Intracranial chronic subdural hematoma presenting with intractable headache after cervical epidural steroid injection. J Korean Neurosurg Soc 2015; 58:144-146.

204. Takawira N, Han RJ, Nguyen TQ, Gaines JD, Han TH. Spinal cord stimulator and epidural haematoma. BJA 2012; 109:649-650.

205. Kloss BT, Sullivan AM, Rodriguez E. Epidural hematoma following spinal cord stimulator implant. Int J Emerg Med 2010; 3:483-484.

206. Smith CC, Lin JL, Shokat M, Dosanjh SS, Casthely D. A report of paraparesis following spinal cord stimulator trial, implantation and revision. Pain Physician 2010; 13:357-363.

207. Santiago FM, Santiago J, Prieto M, García-Sánchez MJ, Sánchez-Carríon JM, Martínez-Tellería A, Garzón A. [Dorsal epidural hematoma after implantation of a dorsal nerve stimulator]. Rev Esp Anestesiol Reanim 2005; 52:440-441.

208. Chen CY, Liu GC, Sheu RS, Huang CL. Bacterial meningitis and lumbar epidural hematoma due to lumbar acupunctures: a case report. Kaohsiung J Med Sci 1997; 13:328-331.

209. Nam KH, Hwa Choi $\mathrm{CH}$, Yang MS, Kang DW. Spinal epidural hematoma after pain control procedure. J Korean Neurosurg Soc 2010; 48:281-284.

210. Jang JS, Jin HY, Seo JS, Yang TH, Kim
DK, Kim DS, Kim DK, Seol SH, Kim DI, Cho KI, Kim BH, Park YH, Je HG, Jeong YH, Kim WJ, Lee JY, Lee SW. A metaanalysis of randomized controlled trials appraising the efficacy and safety of cilostazol after coronary artery stent implantation. Cardiology 2012; 122:133-143.

211. Kolber MR, Korownyk C. An aspirin a day? Aspirin use across a spectrum of risk: Cardiovascular disease, cancers and bleeds. Expert Opin Pharmacother 2014; 15:153-157.

212. Raj PP, Shah RV, Kaye AD, Denaro S, Hoover JM. Bleeding risk in interventional pain practice: Assessment, management, and review of the literature. Pain Physician 2004; 7:3-51.

213. Mallett SV. Clinical utility of viscoelastic tests of coagulation (TEG/ROTEM) in patients with liver disease and during liver transplantation. Semin Thromb Hemost 2015; 41:527-537.

214. Thomas O, Rein H, Strandberg K, Schott $U$. Coagulative safety of epidural catheters after major upper gastrointestinal surgery: advanced and routine coagulation analysis in 38 patients. Perioper Med (Lond) 2016; 5:28.

215. Thomas OD. Haemostatic safety in epidural analgesia. Lund: Lund University, Faculty of Medicine, Doctoral Dissertation Series 2016:117.

http://portal.research.lu.se/portal/ files/15557976/Haemostatic_safety_in_ epidural_analgesia_minus_manus.pdf

216. Forkin KT, Colquhoun DA, Nemergut EC, Huffmeyer JL. The coagulation profile of end-stage liver disease and considerations for intraoperative management. Anesth Analg 2018; 126:46-61.

217. Patrono C, Baigent C, Hirsh J, Roth G; Physicians American College of Chest Physicians. Antiplatelet drugs: American College of Chest Physicians evidencebased clinical practice guidelines (8th Edition). Chest 2008; 133:199S-233S.

218. Moshfegh K, Redondo M, Julmy F, Wuillemin WA, Gebauer MU, Haeberli A, Meyer BJ. Antiplatelet effects of clopidogrel compared with aspirin after myocardial infarction: Enhanced inhibitory effects of combination therapy. J Am Coll Cardiol 2000; 36:699-705.

219. Onyeji CO, Tessier PR, Nightingale $\mathrm{CH}$, Vallee F, Nicolau DP. Pharmacokinetics of ticlopidine in the rabbit]. J Pharm Pharmacol 1999; 51:393-396.

220. Baker WL, White CM. Role of prasugrel, a novel $\mathrm{P}_{2} \mathrm{Y}_{12}$ receptor antagonist, in the management of acute coronary syndromes. Am J Cardiovasc Drugs 2009; 9:213-229.

221. Brandt JT, Close SL, Iturria SJ, Payne CD, Farid NA, Ernest CS 2nd, Lachno DR, Salazar D, Winters KJ. Common polymorphisms of $\mathrm{CYP}_{2} \mathrm{C}_{19}$ and $\mathrm{CYP}_{2} \mathrm{C}_{9}$ affect the pharmacokinetic and pharmacodynamic response to clopidogrel but not prasugrel. J Thromb Haemost 2007; 5:2429-2436.

222. Gu X, Fu X, Wang Y, Zhang W, Fan W, Jiang Y, Hao G, Miao Q, Li Y, Zhi W. Comparison of ticagrelor and high-dose clopidogrel on the platelet functions in patients with inadequate response to clopidogrel. Am J Cardiovasc Dis 2017; 7:1-8.

223. Teng R. Ticagrelor: Pharmacokinetic, pharmacodynamic and pharmacogenetic profile: An update. Clin Pharmacokinet 2015; 54:1125-1138.

224. Teng R, Oliver S, Hayes MA, Butler K. Absorption, distribution, metabolism, and excretion of ticagrelor in healthy subjects. Drug Metab Dispos 2010; 38:1514-1521.

225. Gurbel PA, Bliden KP, Butler K, Tantry US, Gesheff T, Wei C, Teng R, Antonino MJ, Patil SB, Karunakaran A, Kereiakes D), Parris C, Purdy D, Wilson V, Ledley GS, Storey RF. Randomized doubleblind assessment of the ONSET and OFFSET of the antiplatelet effects of ticagrelor versus clopidogrel in patients with stable coronary artery disease: the ONSET/OFFSET study. Circulation 2009; 120:2577-2585.

226. Weber AA, Schrör K. Pharmacology of ticlopidine and clopidogrel in comparison with acetylsalicylic acid. Internist (Berl) 1997; 38:1115-1120.

227. Schror K. The pharmacology of cilostazol. Diabetes Obes Metab 2002; 4:S14-S19.

228. Russell TL, Berardi RR, Barnett JL, O'Sullivan TL, Wagner JG, Dressman JB. $\mathrm{pH}$-related changes in the absorption of dipyridamole in the elderly. Pharm Res 1994; 11:136-143.

229. Woo SK, Kang WK, Kwon KI. Pharmacokinetic and pharmacodynamic modeling of the antiplatelet and cardiovascular effects of cilostazol in healthy humans. Clin Pharmacol Ther 2002; 71:246-252.

230. Lee K, Kim JY, Yoo BS, Yoon J, Hong MK, Ahn MS, Choe H, Lee SH. Cilostazol augments the inhibition of platelet aggregation in clopidogrel low-responders. J Thromb Haemost 2010; 8:2577-2579. 
231. Ikeda $\mathrm{Y}$, Kikuchi M, Murakami H, Satoh K, Murata M, Watanabe K, Ando Y. Comparison of the inhibitory effects of cilostazol, acetylsalicylic acid and ticlopidine on platelet functions ex vivo. Randomized, double-blind cross-over study. Arzneimittelforschung 1987; 37:563-566.

232. Coller BS. Anti-GPIIb/IIla drugs: Current strategies and future directions. Thromb Haemost 2001; 86:427-443.

233. Horlocker TT, Heit JA. Low molecular weight heparin: Biochemistry, pharmacology, perioperative prophylaxis regimens, and guidelines for regional anesthetic management. Anesth Analg 1997; $85: 874-885$.

234. Ansell J, Hirsh J, Hylek E, Jacobson A, Crowther M, Palareti G; American College of Chest Physicians. Pharmacology and management of the vitamin $\mathrm{K}$ antagonists: American College of Chest Physicians Evidence-Based Clinical Practice Guidelines (8th Edition). Chest 2008; 133:160S-198S.

235. Rosencher N, Bonnet MP, Sessler DI. Selected new antithrombotic agents and neuraxial anaesthesia for major orthopaedic surgery: management strategies. Anaesthesia 2007; 62:1154-11660.

236. Dhillon S. Argatroban: A review of its use in the management of heparin-induced thrombocytopenia. Am J Cardiovasc Drugs 2009; 9:261-282.

237. Anand SX, Kim MC, Kamran M, Sharma SK, Kini AS, Fareed J, Hoppensteadt DA, Carbon F, Cavusoglu E, Varon D, VilesGonzalez JF, Badimon JJ, Marmur JD. Comparison of platelet function and morphology in patients undergoing percutaneous coronary intervention receiving bivalirudin versus unfractionated heparin versus clopidogrel pretreatment and bivalirudin. Am J Cardiol 2007; 100:417-424.

238. Nafziger AN, Bertino JS. Desirudin dosing and monitoring in moderate renal impairment. J Clin Pharmacol 2010; 50:614-622.

239. Rydel TJ, Tulinsky A, Bode W, Huber R. Refined structure of the hirudinthrombin complex. J Mol Biol 1991; 221:583-601.

240. Andexxa-An antidote for apixaban and rivaroxaban. JAMA 2018; 320:399-400.

241. Plosker GL. Rivaroxaban: A review of its use in acute coronary syndromes. Drugs 2014; 74:451-464.

242. Frost C, Wang J, Nepal S, Schuster A, Barrett YC, Mosqueda-Garcia R, Reeves RA, LaCreta. Apixaban, an oral, direct factor Xa inhibitor: Single dose safety, pharmacokinetics, pharmacodynamics and food effect in healthy subjects. $\mathrm{Br}$ J Pharmacol 2013; 75:476-487.

243. Frost C, Nepal S, Wang J, Schuster A, Byon W, Boyd RA, Yu Z, Shenker A, Barrett YC, Mosqueda-Garcia R, Lacreta F. Safety, pharmacokinetics and pharmacodynamics of multiple oral doses of apixaban, a factor $\mathrm{Xa}$ inhibitor, in healthy subjects. $\mathrm{Br} \mathrm{J}$ Clin Pharmacol 2013; 76:776-786.

244. Raghavan N, Frost CE, Yu Z, He K, Zhang $H$, Humphreys WG, Pinto $D$, Chen S, Bonacorsi S, Wong PC, Zhang D. Apixaban metabolism and pharmacokinetics after oral administration to humans. Drug Metab Dispos 2009; 37:74-81.

245. Stacy ZA, Call WB, Hartmann AP, Peters GL, Richter SK. Edoxaban: A comprehensive review of the pharmacology and clinical data for the management of atrial fibrillation and venous thromboembolism. Cardiol Ther 2016; 5:1-18.

246. Zhang $P$, Huang $W$, Wang L, Bao L, Jia Z), Bauer SM, Goldman EA, Probst GD, Song Y, Su T, Fan J, Wu Y, Li W, Woolfrey J, Sinha U, Wong PW, Edwards ST, Arfsten AE, Clizbe LA, Kanter J, Pandey A, Park G, Hutchaleelaha A, Lambing JL, Hollenbach SJ, Scarborough RM, Zhu BY. Discovery of betrixaban (PRT054021), $\mathrm{N}$-(5-chloropyridin-2-yl)-2-(4-(N,Ndimethylcarbamimidoyl) benzamido)5-methoxybenzamide, a highly potent, selective, and orally efficacious factor Xa inhibitor [Internet]. Bioorg Med Chem Lett 2009; 19:2179-2185.

247. Turpie AG, Bauer KA, Davidson BL, Fisher WD, Gent $M$, Huo $M H$, Sinha U, Gretler DD; EXPERT Study Group. A randomized evaluation of betrixaban, an oral factor Xa inhibitor, for prevention of thromboembolic events after total knee replacement (EXPERT). Thromb Haemost 2009; 101:68-76.

248. Piccini JP, Lopes RD, Mahaffey KW. Oral factor $\mathrm{Xa}$ inhibitors for the prevention of stroke in atrial fibrillation. Curr Opin Cardiol 2010; 25:312-320.

249. Bauer KA. Fondaparinux: Basic properties and efficacy and safety in venous thrombo-embolism prophylaxis. Am J Orthop (Belle Mead. NJ) 2002; 31:4-10.

250. Turpie AG, Gallus AS, Hoek JA; Pentasaccharide Investigators. A synthetic pentasaccharide for the prevention of deepvein thrombosis after total hip replacement. N Engl J Med 2001; 344:619-625.

251. Horlocker TT, Wedel DJ, Rowlingson
JC, Enneking FK, Kopp SL, Benzon HT, Brown DL, Heit JA, Mulroy MF, Rosenquist RW, Tryba M, Yuan CS. Regional anesthesia in the patient receiving antithrombotic or thrombolytic therapy: American Society of Regional Anesthesia and Pain Medicine evidence-based guidelines (third edition). Reg Anesth Pain Med 2010; 35:64-101.

252. Srivastava KC. Evidence for the mechanism by which garlic inhibits platelet aggregation. Prostaglandins Leukot Med 1986; 22:313-321.

253. Rendu F, Daveloose D, Debouzy JC, Bourdeau N, Levy-Toledano S, Jain MK, Apitz-Castro R. Ajoene, the antiplatelet compound derived from garlic, specifically inhibits platelet release reaction by affecting the plasma membrane internal microviscosity. Biochem Pharmacol 1989; 38:1321-1328.

254. Biber A. Pharmacokinetics of ginkgo biloba extracts. Pharmacopsychiatry 2003; 36:S32-S 37.

255. He H, Ke B, Li Y, Han F, Li X, Zeng Y. Novel oral anticoagulants in the preoperative period: A meta-analysis. J Thromb Thrombolysis 2018; 45:386-396.

256. Puelacher C, Lurati-Buse G, Singeisen H, Dang M, Cuculi F, Müller C. Perioperative myocardial infarction/injury after noncardiac surgery. Swiss Med Wkly 2015; 145:W14219.

257. Chassot PG, Delabays A, Spahn DR. Perioperative antiplatelet therapy: The case for continuing therapy in patients at risk of myocardial infarction. $\mathrm{Br}$ J Anaesth 2007; 99:316-328.

258. Dawood MM, Gutpa DK, Southern J, Walia A, Atkinson JB, Eagle KA. Pathology of fatal perioperative myocardial infarction: Implications regarding physiopathology and prevention. Int J Cardiol 1996; 57:37-44.

259. Landesberg G. The pathophysiology of perioperative myocardial infarction: Facts and perspectives. J Cardiothorac Vasc Anesth 2003; 17:90-100.

26o. Priebe HJ. Triggers of perioperative myocardial ischaemia and infarction. $\mathrm{Br}$ J Anaesth 2004; 93:9-20.

261. Priebe HJ. Perioperative myocardial infarction-aetiology and prevention. $\mathrm{Br}$ ] Anaesth 2005; 95:3-19.

262. Hoffmeister HM, Heller W, Seipel L. Activation markers of coagulation and fibrinolysis: Alterations and predictive value in acute coronary syndrome. Thromb Haemostasis 1999; 82:76-79. 
263. Blake GJ, Ridker PM. Inflammatory biomarkers and cardiovascular risk prediction. J Intern Med 2002; 252:283-294.

264. Steib A, Hadjiat F, Skibba W, Steib JP, French Spine Surgery Society. Focus on perioperative management of anticoagulants and antiplatelet agents in spine surgery. Orthop Traumatol Surg Res 2011; 97:S102-s106.

265. Macellari F, Paciaroni M, Agnelli G, Caso V. Perioperative stroke risk in nonvascular surgery. Cerebrovasc Dis 2012; 34:175-181.

266. Antolovic D, Reissfelder C, Rakow A, Contin P, Rahbari NN, Büchler MW, Weitz J, Koch M. A randomised controlled trial to evaluate and optimize the use of antiplatelet agents in the perioperative management in patients undergoing general and abdominal surgery-the APAP trial (ISRCTN45810007). BMC Surg 2011; $11: 7$.

267. Chassot PG, Marcucci C, Delabays A, Spahn DR. Perioperative antiplatelet therapy. Am Fam Physician 2010; 82:1484-1489.

268. Korte W, Cattaneo M, Chassot PG, Eichinger $S$, von Heymann $C$, Hofmann $\mathrm{N}$, Rickli H, Spannagl M, Ziegler B, Verheugt F, Huber K. Peri-operative management of antiplatelet therapy in patients with coronary artery disease: Joint position paper by members of the working group on Perioperative Haemostasis of the Society on Thrombosis and Haemostasis Research (GTH), the working group on Perioperative Coagulation of the Austrian Society for Anesthesiology, Resuscitation and Intensive Care (ÖGARI) and the Working Group Thrombosis of the European Society for Cardiology (ESC). Thromb Haemost 2011; 105:743-749.

269. Savonitto S, Caracciolo M, Cattaneo M, DE Servi S. Management of patients with recently implanted coronary stents on dual antiplatelet therapy who need to undergo major surgery. J Thromb Haemost 2011; 9:2133-2142.

270. Bell B, Layland J, Poon K, Spaulding C, Walters D. Focused clinical review: Periprocedural management of antiplatelet therapy in patients with coronary stents. Heart Lung Circ 2011; 20:438-445.

271. Tan VP, Yan BP, Kiernan TJ, Ajani AE. Risk and management of upper gastrointestinal bleeding associated with prolonged dual-antiplatelet therapy after percutaneous coronary intervention. Cardiovasc Revasc Med 2009; 10:36-44.
272. Grines $\mathrm{CL}$, Bonow RO, Casey $\mathrm{DE} J \mathrm{~J}$, Gardner TJ, Lockhart PB, Moliterno DJ, O'Gara P, Whitlow P; American Heart Association; American College of Cardiology; Society for Cardiovascular Angiography and Interventions; American College of Surgeons; American Dental Association; American College of Physicians. Prevention of premature discontinuation of dual antiplatelet therapy in patients with coronary artery stents: A science advisory from the American Heart Association, American College of Cardiology, Society for Cardiovascular Angiography and Interventions, American College of Surgeons, and American Dental Association, with representation from the American College of Physicians. J Am Dent Assoc 2007; 138:652-655.

273. Chassot PG, Delabays A, Spahn DR. Perioperative use of anti-platelet drugs. Best Pract Res Clin Anaesthesiol 2007; 21:241-256.

274. Ray JG, Deniz S, Olivieri A, Pollex E, Vermeulen MJ, Alexander KS, Cain DJ, Cybulsky I, Hamielec CM. Increased blood product use among coronary artery bypass patients prescribed preoperative aspirin and clopidogrel. BMC Cardiovasc Disord 2003; 3:3.

275. Michlig C, Vu DH, Wasserfallen JB, Spahn DR, Schneider P, Tissot JD. Three years of haemo-vigilance in a general university hospital. Transfus Med 2003; 13:63-72.

276. Kearon C, Hirsh J. Current concepts: Management of anticoagulation before and after elective surgery. $\mathrm{N} \mathrm{Engl} \mathrm{J} \mathrm{Med}$ 1997; 336:1506-1511.

277. Vial JH, McLeod LJ, Roberts MS. Rebound elevation in urinary thromboxane $\mathrm{B}_{2}$ and 6-keto-PFFi alpha exacerbation after aspirin withdrawal. Adv Prostaglandin Thromboxane Leukot Res 1991; 21A:157-160.

278. Weber AA, Braun M, Hohlfeld T, Schwippert B, Tschöpe D, Schrör K. Recovery of platelet function after discontinuation of clopidogrel treatment in healthy volunteers. $\mathrm{Br}$ J Clin Pharmacol 2001; 52:333-336.

279. Vilahur G, Choi BG, Zafar MU, VilesGonzalez JF, Vorchheimer DA, Fuster $\mathrm{V}$, Badimon JJ. Normalization of platelet reactivity in clopidogrel-treated subjects. J Thromb Haemost 2007; 5:82-90.

280. Collet JP, Montalescot G, Blanchet B, Tanguy ML, Golmard JL, Choussat R, Beygui F, Payot L, Vignolles N, Metzger
JP, Thomas D. Impact of prior use or recent withdrawal of oral antiplatelet agents on acute coronary syndrome. Circulation 2004; 110:2361-2367.

281. Howard-Alpe GM, de Bono J, Hudsmith L, Orr WP, Foex P, Sear JW. Coronary artery stents and non-cardiac surgery. $\mathrm{Br}$ ] Anaesth 2007; 98:560-574.

282. Sharma AK, Ajani AE, Hamwi SM, Maniar P, Lakhani SV, Waksman R, Lindsay J. Major noncardiac surgery following coronary stenting: When is it safe to operate? Catheter Cardiovasc Interv 2004; 63:141-145.

283. lakovou I, Schmidt T, Bonizzoni E, Ge L, Sangiorgi GM, Stankovic G, Airoldi F, Chieffo A, Montorfano M, Carlino M, Michev I, Corvaja N, Briguori C, Gerckens U, Grube E, Colombo A. Incidence, predictors, and outcome of thrombosis after successful implantation of drug eluting stents. JAMA 2005; 293:2126-2130.

284. Horlocker TT, Wedel DJ, Schroeder DR, Rose SH, Elliott BA, McGregor DG, Wong GY. Preoperative antiplatelet therapy does not increase the risk of spinal hematoma associated with regional anesthesia. Anesth Analg 1995; 80:303-309.

285. Horlocker TT, Wedel DJ, Offord KP. Does preoperative antiplatelet therapy increase the risk of hemorrhagic complications associated with regional anesthesia? Anesth Analg 1990; 70:631-634.

286. Wamala H, Scott IA, Caney X. Perioperative management of new oral anticoagulants in patients undergoing elective surgery at a tertiary hospital. Intern Med J 2017; 47:1412-1421.

287. Lum DJ, Ross PA, Bishop MA, Caetano $M L$, Malpani R, Streiff MB. Evaluation of a standardized perioperative management protocol in the adult hematology anticoagulation management service. Ann Pharmacother 2017; 51:1077-1083.

288. Sun MT, Wood MK, Chan W, Selva D, Sanders P, Casson RJ, Wong CX. Risk of intraocular bleeding with novel oral anticoagulants compared with warfarin: A systematic review and meta-analysis. JAMA Ophthalmol 2017; 135:864-870.

289. Irizarry-Alvarado JM, Seim LA. Perioperative management of anticoagulants. Curr Clin Pharmacol 2017; 12:145-151.

290. Duranteau J, Taccone FS, Verhamme P, Ageno W, ESA VTE Guidelines Task Force. European guidelines on perioperative venous thromboembolism pro- 
phylaxis: Intensive care. Eur J Anaesthesiol 2018; 35:142-146.

291. Khan H, Kumar V, Ghulam-Jelani Z, McCallum SE, Hobson E, Sukul V, Pilitsis JG. Safety of spinal cord stimulation in patients who routinely use anticoagulants. Pain Med 2018; 19:1807-1812.

292. Childers $C P$, Maggard-Gibbons $M$, Ulloa JG, MacQueen IT, Miake-Lye IM, Shanman R, Mak S, Beroes JM, Shekelle PG. Perioperative management of antiplatelet therapy in patients undergoing non-cardiac surgery following coronary stent placement: A systematic review. Syst Rev 2018; 7:4.

293. Sobieraj DM, Coleman Cl, Pasupuleti V, Deshpande A, Kaw R, Hernandez AV. Comparative efficacy and safety of anticoagulants and aspirin for extended treatment of venous thromboembolism: A network meta-analysis. Thromb Res 2015; 135:888-896.

294. Akl EA, Kahale L, Terrenato I, Neumann I, Yosuico VE, Barba M, Sperati F, Schünemann $\mathrm{H}$. Oral anticoagulation in patients with cancer who have no therapeutic or prophylactic indication for anticoagulation. Cochrane Database Syst Rev 2014; (7):CDo06466.

295. Rollins BM, Silva MA, Donovan JL, Kanaan AO. Evaluation of oral anticoagulants for the extended treatment of venous thromboembolism using a mixedtreatment comparison, meta-analytic approach. Clin Ther 2014; 36:1454-1464.

296. Hernandez I, Zhang Y, Saba S. Comparison of the effectiveness and safety of apixaban, dabigatran, rivaroxaban, and warfarin in newly diagnosed atrial fibrillation. Am J Cardiol 2017; 120:1813-1819.

297. de Souza Brito F, Mehta RH, Lopes RD, Harskamp RE, Lucas BD Jr, Schulte PJ, Tardif JC, Alexander JH. Nonsteroidal anti-inflammatory drugs and clinical outcomes in patients undergoing coronary artery bypass surgery. Am J Med 2017; 130:462-468.

298. Hess PL, Kim S, Fonarow GC, Thomas L, Singer DE, Freeman JV, Gersh BJ, Ansell J, Kowey PR, Mahaffey KW, Chan PS, Steinberg BA, Peterson ED, Piccini JP; Outcomes Registry for Better Informed Treatment of Atrial Fibrillation (ORBITAF) Patients and Investigators. Absence of oral anticoagulation and subsequent outcomes among outpatients with atrial fibrillation. Am J Med 2017; 130:449-456.

299. Dunn AS, Turpie AG. Perioperative management of patients receiving oral anticoagulants: A systematic review. Arch Intern Med 2003; 163:901-908.
300. Ono S, Fujishiro M, Kanzaki H, Uedo N, Yokoi C, Akiyama J, Sugawara M, Oda I, Suzuki S, Fujita Y, Tsubata S, Hirano M, Fukuzawa M, Kataoka M, Kamoshida T, Hirai S, Sumiyoshi T, Kondo H, Yamamoto Y, Okada K, Morita Y, Fujiwara S, Morishita S, Matsumoto M, Koike K. Conflicting clinical environment about the management of antithrombotic agents during the periendoscopic period in Japan. J Gastroenterol Hepatol 2011; 26:1434-1440.

301. Ono S, Fujishiro M, Kodashima S, Takahashi Y, Minatsuki C, Mikami-Matsuda R, Asada-Hirayama I, Konno-Shimizu M, Tsuji Y, Mochizuki S, Niimi K, Yamamichi N, Kaneko M, Yatomi Y, Koike K. Evaluation of safety of endoscopic biopsy without cessation of antithrombotic agents in Japan. J Gastroenterol 2012; 47:770-774.

302. Stone DH, Goodney PP, Schanzer A, NoIan BW, Adams JE, Powell RJ, Walsh DB, Cronenwett JL; Vascular Study Group of New England. Clopidogrel is not associated with major bleeding complications during peripheral arterial surgery. J Vasc Surg 2011; 54:779-784.

303. Lip GY, Durrani OM, Roldan V, Lip PL, Marin F, Reuser TQ. Peri-operative management of ophthalmic patients taking antithrombotic therapy. Int J Clin Pract 2011; 65:361-371.

304. Gerstein NS, Schulman PM, Gerstein WH, Petersen TR, Tawil I. Should more patients continue aspirin therapy perioperatively?: Clinical impact of aspirin withdrawal syndrome. Ann Surg 2012; 255:811-819.

305. Law SK, Song BJ, Yu F, Kurbanyan K, Yang TA, Caprioli J. Hemorrhagic complications from glaucoma surgery in patients on anticoagulation therapy or antiplatelet therapy. Am J Ophthalmol 2008; 145:736-746.

306. Lee LA, Posner KL, Kent CD, Domino KB. Complications associated with peripheral nerve blocks: Lessons from the ASA Closed Claims Project. Int Anesthesiol Clin 2011; 49:56-67.

307. Lee LA, Posner KL, Domino KB, Caplan RA, Cheney FW. Injuries associated with regional anesthesia in the 1980 s and 1990s: A closed claims analysis. Anesthesiology 2004; 101:143-152.

308. Cook TM, Counsell D, Wildsmith JA; Royal College of Anaesthetists Third National Audit Project. Major complications of central neuraxial block: Report on the Third National Audit Project of the Royal College of Anaesthetists. $\mathrm{Br}$ ] Anaesth 2009; 102:179-190.

309. Tam NL, Pac-Soo C, Pretorius PM. Epidural haematoma after a combined spinal- epidural anaesthetic in a patient treated with clopidogrel and dalteparin. $\mathrm{Br}$ ] Anaesth 2006; 96:262-265.

310. Stafford-Smith M. Impaired haemostasis and regional anaesthesia. Can J Anaesth 1996; 43:R129-R141.

311. Moen V, Dahlgren N, Irestedt L. Severe neurological complications after central neuraxial blockades in Sweden 19901999. Anesthesiology 2004; 101:950-959.

312. Chan L, Bailin MT. Spinal epidural hematoma following central neuraxial blockade and subcutaneous enoxaparin: A case report. J Clin Anesth 2004; 16:382-385.

313. Kreppel D, Antoniadis G, Seeling W. Spinal hematoma: A literature survey with meta-analysis of 613 patients. Neurosurg Rev 2003; 26:1-49.

314. Bajkin BV, Popovic SL, Selakovic SDJ. Randomized, prospective trial comparing bridging therapy using low-molecular-weight heparin with maintenance of oral anticoagulation during extraction of teeth. J Oral Maxillofac Surg 2009; 67:990-995.

315. Douketis JD, Spyropoulos AC, Kaatz S, Becker RC, Caprini JA, Dunn AS, Garcia DA, Jacobson A, Jaffer AK, Kong DF, Schulman S, Turpie AG, Hasselblad V, Ortel TL; BRIDGE Investigators. Perioperative bridging anticoagulation in patients with atrial fibrillation. $N$ Engl J Med 2015; 373:823-833.

316. Douketis JD, Spyropoulos AC, Spencer FA, Mayr M, Jaffer AK, Eckman MH, Dunn AS, Kunz R. Perioperative management of antithrombotic therapy: Antithrombotic Therapy and Prevention of Thrombosis, 9th ed: American College of Chest Physicians Evidence-Based Clinical Practice Guidelines. Chest 2012; 141:e326S-e350S.

317. January CT, Wann LS, Alpert JS, Calkins $\mathrm{H}$, Cigarroa JE, Cleveland JC Jr, Conti JB, Ellinor PT, Ezekowitz MD, Field ME, Murray KT, Sacco RL, Stevenson WG, Tchou PJ, Tracy CM, Yancy CW; American College of Cardiology/American Heart Association Task Force on Practice Guidelines. 2014 AHA/ACC/HRS guideline for the management of patients with atrial fibrillation: A report of the American College of Cardiology/ American Heart Association Task Force on Practice Guidelines and the Heart 
Rhythm Society. J Am Coll Cardiol 2014; 64:e1-76.

318. U.S. National Library of Medicine. ClinicalTrials.gov. PERIOP 2 - A Safety and Effectiveness of LMWH vs Placebo Bridging Therapy for Patients on Long Term
Warfarin Requiring Temporary Interruption of Warfarin. ClinicalTrials.gov Identifier: NCTo0432796

https://clinicaltrials.gov/ct2/show/ NCTo0432796A

319. Rechenmacher SJ, Fang JD. Bridging an- ticoagulation: Primum non nocere. ] Am Coll Cardiol 2015; 66:1392-1403.

320. Christos S, Naples R. Anticoagulation reversal and treatment strategies in major bleeding: Update 2016. West J Emerg Med 2016; 17:264-270. 
Appendix Table 1. Sources of risk of bias and Cochrane Review rating system.

\begin{tabular}{|c|c|c|c|}
\hline Bias Domain & \multicolumn{2}{|l|}{ Source of Bias } & Possible \\
\hline \multirow[t]{2}{*}{ Selection } & \multirow[t]{2}{*}{$\begin{array}{l}\text { (1) Was the method of } \\
\text { randomization adequate? }\end{array}$} & $\begin{array}{l}\text { A random (unpredictable) assignment sequence. Examples of adequate } \\
\text { methods are coin toss (for studies with } 2 \text { groups), rolling a dice (for } \\
\text { studies with } 2 \text { or more groups), drawing of balls of different colors, } \\
\text { drawing of ballots with the study group labels from a dark bag, computer- } \\
\text { generated random sequence, preordered sealed envelopes, sequentially- } \\
\text { ordered vials, telephone call to a central office, and preordered list of } \\
\text { treatment assignments. }\end{array}$ & \multirow[t]{2}{*}{ Yes/No/Unsure } \\
\hline & & $\begin{array}{l}\text { Examples of inadequate methods are: alternation, birth date, social } \\
\text { insurance/security number, date in which they are invited to participate } \\
\text { in the study, and hospital registration number. }\end{array}$ & \\
\hline Selection & $\begin{array}{l}\text { (2) Was the treatment } \\
\text { allocation concealed? }\end{array}$ & $\begin{array}{l}\text { Assignment generated by an independent person not responsible for } \\
\text { determining the eligibility of the patients. This person has no information } \\
\text { about the persons included in the trial and has no influence on the } \\
\text { assignment sequence or on the decision about eligibility of the patient. }\end{array}$ & Yes/No/Unsure \\
\hline Performance & $\begin{array}{l}\text { (3) Was the patient blinded to } \\
\text { the intervention? }\end{array}$ & $\begin{array}{l}\text { Index and control groups are indistinguishable for the patients or if the } \\
\text { success of blinding was tested among the patients and it was successful. }\end{array}$ & Yes/No/Unsure \\
\hline Performance & $\begin{array}{l}\text { (4) Was the care provider } \\
\text { blinded to the intervention? }\end{array}$ & $\begin{array}{l}\text { Index and control groups are indistinguishable for the care providers or } \\
\text { if the success of blinding was tested among the care providers and it was } \\
\text { successful. }\end{array}$ & Yes/No/Unsure \\
\hline \multirow[t]{6}{*}{ Detection } & \multirow[t]{6}{*}{$\begin{array}{l}\text { (5) Was the outcome assessor } \\
\text { blinded to the intervention? }\end{array}$} & $\begin{array}{l}\text { Adequacy of blinding should be assessed for each primary outcome } \\
\text { separately. This item should be scored "yes" if the success of blinding was } \\
\text { tested among the outcome assessors and it was successful or: }\end{array}$ & \multirow[t]{6}{*}{ Yes/No/Unsure } \\
\hline & & $\begin{array}{l}\text { - for patient-reported outcomes in which the patient is the outcome } \\
\text { assessor (e.g., pain, disability): the blinding procedure is adequate for } \\
\text { outcome assessors if participant blinding is scored "yes" }\end{array}$ & \\
\hline & & $\begin{array}{l}\text { - for outcome criteria assessed during scheduled visit and that supposes } \\
\text { a contact between participants and outcome assessors (e.g., clinical } \\
\text { examination): the blinding procedure is adequate if patients are blinded, } \\
\text { and the treatment or adverse effects of the treatment cannot be noticed } \\
\text { during clinical examination }\end{array}$ & \\
\hline & & $\begin{array}{l}\text { - for outcome criteria that do not suppose a contact with participants } \\
\text { (e.g., radiography, magnetic resonance imaging): the blinding procedure } \\
\text { is adequate if the treatment or adverse effects of the treatment cannot be } \\
\text { noticed when assessing the main outcome }\end{array}$ & \\
\hline & & $\begin{array}{l}\text { - for outcome criteria that are clinical or therapeutic events that will be } \\
\text { determined by the interaction between patients and care providers (e.g., } \\
\text { cointerventions, hospitalization length, treatment failure), in which the } \\
\text { care provider is the outcome assessor: the blinding procedure is adequate } \\
\text { for outcome assessors if item " } 4 \text { " (caregivers) is scored "yes" }\end{array}$ & \\
\hline & & $\begin{array}{l}\text { - for outcome criteria that are assessed from data of the medical forms: } \\
\text { the blinding procedure is adequate if the treatment or adverse effects of } \\
\text { the treatment cannot be noticed on the extracted data }\end{array}$ & \\
\hline Attrition & $\begin{array}{l}\text { (6) Was the drop-out rate } \\
\text { described and acceptable? }\end{array}$ & $\begin{array}{l}\text { The number of participants who were included in the study but did not } \\
\text { complete the observation period or were not included in the analysis } \\
\text { must be described and reasons given. If the percentage of withdrawals } \\
\text { and drop-outs does not exceed } 20 \% \text { for short-term follow-up and } 30 \% \\
\text { for long-term follow-up and does not lead to substantial bias a "yes" is } \\
\text { scored. (N.B. these percentages are arbitrary, not supported by literature). }\end{array}$ & Yes/No/Unsure \\
\hline Attrition & $\begin{array}{l}\text { (7) Were all randomized } \\
\text { participants analyzed in the } \\
\text { group to which they were } \\
\text { allocated? }\end{array}$ & $\begin{array}{l}\text { All randomized patients are reported/analyzed in the group they were } \\
\text { allocated to by randomization for the most important moments of effect } \\
\text { measurement (minus missing values) irrespective of noncompliance and } \\
\text { cointerventions. }\end{array}$ & Yes/No/Unsure \\
\hline
\end{tabular}


Appendix Table 1. Sources of risk of bias and Cochrane Review rating system.

\begin{tabular}{|c|c|c|c|}
\hline Bias Domain & \multicolumn{2}{|l|}{ Source of Bias } & \multirow{2}{*}{$\begin{array}{l}\text { Possible } \\
\text { Answers } \\
\text { Yes/No/Unsure }\end{array}$} \\
\hline Reporting & $\begin{array}{l}\text { (8) Are reports of the study } \\
\text { free of suggestion of selective } \\
\text { outcome reporting? }\end{array}$ & $\begin{array}{l}\text { All the results from all prespecified outcomes have been adequately } \\
\text { reported in the published report of the trial. This information is either } \\
\text { obtained by comparing the protocol and the report, or in the absence } \\
\text { of the protocol, assessing that the published report includes enough } \\
\text { information to make this judgment. }\end{array}$ & \\
\hline Selection & $\begin{array}{l}\text { (9) Were the groups similar } \\
\text { at baseline regarding the } \\
\text { most important prognostic } \\
\text { indicators? }\end{array}$ & $\begin{array}{l}\text { Groups have to be similar at baseline regarding demographic factors, } \\
\text { duration and severity of complaints, percentage of patients with } \\
\text { neurological symptoms, and value of main outcome measure(s). }\end{array}$ & Yes/No/Unsure \\
\hline Performance & $\begin{array}{l}\text { (10) Were cointerventions } \\
\text { avoided or similar? }\end{array}$ & $\begin{array}{l}\text { If there were no cointerventions or they were similar between the index } \\
\text { and control groups. }\end{array}$ & Yes/No/Unsure \\
\hline Performance & $\begin{array}{l}\text { (11) Was the compliance } \\
\text { acceptable in all groups? }\end{array}$ & $\begin{array}{l}\text { The reviewer determines if the compliance with the interventions is } \\
\text { acceptable, based on the reported intensity, duration, number and } \\
\text { frequency of sessions for both the index intervention and control } \\
\text { intervention(s). For example, physiotherapy treatment is usually } \\
\text { administered for several sessions; therefore it is necessary to assess how } \\
\text { many sessions each patient attended. For single-session interventions } \\
\text { (e.g., surgery), this item is irrelevant. }\end{array}$ & Yes/No/Unsure \\
\hline Detection & $\begin{array}{l}\text { (12) Was the timing of the } \\
\text { outcome assessment similar } \\
\text { in all groups? }\end{array}$ & $\begin{array}{l}\text { Timing of outcome assessment should be identical for all intervention } \\
\text { groups and for all primary outcome measures. }\end{array}$ & Yes/No/Unsure \\
\hline \multirow[t]{2}{*}{ Other } & \multirow{2}{*}{$\begin{array}{l}\text { (13) Are other sources of } \\
\text { potential bias unlikely? }\end{array}$} & Other types of biases. For example: & \multirow[t]{2}{*}{ Yes/No/Unsure } \\
\hline & & $\begin{array}{l}\text { - When the outcome measures were not valid. There should be evidence } \\
\text { from a previous or present scientific study that the primary outcome can } \\
\text { be considered valid in the context of the present. } \\
\text { - Industry-sponsored trials. The conflict of interest (COI) statement } \\
\text { should explicitly state that the researchers have had full possession of the } \\
\text { trial process from planning to reporting without funders with potential } \\
\text { COI having any possibility to interfere in the process. If, for example, } \\
\text { the statistical analyses have been done by a funder with a potential COI, } \\
\text { usually "unsure" is scored. }\end{array}$ & \\
\hline
\end{tabular}

Source: Furlan AD, et al. 2015 Updated Method Guideline for Systematic Reviews in the Cochrane Back and Neck Group. Spine (Phila Pa 1976) 2015; 40:1660-1673 (165). 
Appendix Table 2. Item checklist for assessment of randomized controlled trials of IPM techniques utilizing IPM-QRB.

\begin{tabular}{|c|c|c|}
\hline & & $\overline{\text { Scoring }}$ \\
\hline I. & TRIAL DESIGN AND GUIDANCE REPORTING & \\
\hline \multirow[t]{5}{*}{1.} & CONSORT or SPIRIT & \\
\hline & Trial designed and reported without any guidance & 0 \\
\hline & $\begin{array}{l}\text { Trial designed and reported utilizing minimum criteria other than CONSORT or SPIRIT criteria or trial was conducted } \\
\text { prior to } 2005\end{array}$ & 1 \\
\hline & $\begin{array}{l}\text { Trial implies it was based on CONSORT or SPIRIT without clear description with moderately significant criteria for } \\
\text { randomized trials or the trial was conducted before } 2005\end{array}$ & 2 \\
\hline & $\begin{array}{l}\text { Explicit use of CONSORT or SPIRIT with identification of criteria or trial conducted with high level reporting and criteria } \\
\text { or conducted before } 2005\end{array}$ & 3 \\
\hline II. & DESIGN FACTORS & \\
\hline \multirow[t]{4}{*}{2.} & Type and Design of Trial & \\
\hline & Poorly designed control group (quasi selection, convenient sampling) & 0 \\
\hline & Proper active-control or sham procedure with injection of active agent & 2 \\
\hline & Proper placebo control (no active solutions into active structures) & 3 \\
\hline \multirow[t]{4}{*}{3.} & Setting/Physician & \\
\hline & General setting with no specialty affiliation and general physician & 0 \\
\hline & Specialty of anesthesia/PMR/neurology/radiology/ortho, etc. & 1 \\
\hline & Interventional pain management with interventional pain management physician & 2 \\
\hline \multirow[t]{5}{*}{4.} & Imaging & \\
\hline & Blind procedures & 0 \\
\hline & Ultrasound & 1 \\
\hline & $\mathrm{CT}$ & 2 \\
\hline & Fluoro & 3 \\
\hline \multirow[t]{5}{*}{5.} & Sample Size & \\
\hline & Less than 50 participants in the study without appropriate sample size determination & 0 \\
\hline & Sample size calculation with less than 25 patients in each group & 1 \\
\hline & Appropriate sample size calculation with at least 25 patients in each group & 2 \\
\hline & Appropriate sample size calculation with 50 patients in each group & 3 \\
\hline \multirow[t]{3}{*}{6.} & Statistical Methodology & \\
\hline & None or inappropriate & 0 \\
\hline & Appropriate & 1 \\
\hline III. & PATIENT FACTORS & \\
\hline 7. & Inclusiveness of Population & \\
\hline \multirow[t]{4}{*}{$7 \mathrm{a}}$. & For epidural procedures: & \\
\hline & Poorly identified mixed population & 0 \\
\hline & Clearly identified mixed population & 1 \\
\hline & $\begin{array}{l}\text { Disorders specific trials (i.e. well defined spinal stenosis and disc herniation, disorder specific, disc herniation or spinal } \\
\text { stenosis or post surgery syndrome) }\end{array}$ & 2 \\
\hline \multirow[t]{4}{*}{$7 \mathrm{~b}}$. & For facet or sacroiliac joint interventions: & \\
\hline & No diagnostic blocks & 0 \\
\hline & Selection with single diagnostic blocks & 1 \\
\hline & Selection with placebo or dual diagnostic blocks & 2 \\
\hline
\end{tabular}


Appendix Table 2 con't. Item checklist for assessment of randomized controlled trials of IPM techniques utilizing IPM-QRB.

\begin{tabular}{|c|c|c|}
\hline & & Scoring \\
\hline \multirow[t]{4}{*}{8.} & Duration of Pain & \\
\hline & Less than 3 months & 0 \\
\hline & 3 to 6 months & 1 \\
\hline & $>6$ months & 2 \\
\hline \multirow[t]{5}{*}{9.} & Previous Treatments & \\
\hline & Conservative management including drug therapy, exercise therapy, physical therapy, etc. & \\
\hline & Were not utilized & 0 \\
\hline & Were utilized sporadically in some patients & 1 \\
\hline & Were utilized in all patients & 2 \\
\hline \multirow[t]{5}{*}{10.} & Duration of Follow-up with Appropriate Interventions & \\
\hline & $\begin{array}{l}\text { Less than } 3 \text { months or } 12 \text { weeks for epidural or facet joint procedures, etc. and } 6 \text { months for intradiscal procedures and } \\
\text { implantables }\end{array}$ & 0 \\
\hline & 3 to 6 months for epidural or facet joint procedures, etc., or 1 year for intradiscal procedures or implantables & 1 \\
\hline & $\begin{array}{l}6 \text { months to } 17 \text { months for epidurals or facet joint procedures, etc., and } 2 \text { years or longer for discal procedures and } \\
\text { implantables }\end{array}$ & 2 \\
\hline & $\begin{array}{l}18 \text { months or longer for epidurals and facet joint procedures, etc., or } 5 \text { years or longer for discal procedures and } \\
\text { implantables }\end{array}$ & 3 \\
\hline IV. & OUTCOMES & \\
\hline \multirow[t]{6}{*}{11.} & Outcomes Assessment Criteria for Significant Improvement & \\
\hline & $\begin{array}{l}\text { No descriptions of outcomes } \\
\text { OR } \\
<20 \% \text { change in pain rating or functional status }\end{array}$ & 0 \\
\hline & $\begin{array}{l}\text { Pain rating with a decrease of } 2 \text { or more points or more than } 20 \% \text { reduction } \\
\text { OR } \\
\text { functional status improvement of more than } 20 \%\end{array}$ & 1 \\
\hline & $\begin{array}{l}\text { Pain rating with decrease of } \geq 2 \text { points } \\
\text { AND } \\
\geq 20 \% \text { change or functional status improvement of } \geq 20 \%\end{array}$ & 2 \\
\hline & $\begin{array}{l}\text { Pain rating with a decrease of } 3 \text { or more points or more than } 50 \% \text { reduction } \\
\text { OR } \\
\text { functional status improvement with a } 50 \% \text { or } 40 \% \text { reduction in disability score }\end{array}$ & 2 \\
\hline & Significant improvement with pain and function $\geq 50 \%$ or 3 points and $40 \%$ reduction in disability scores & 4 \\
\hline \multirow[t]{4}{*}{12.} & Analysis of all Randomized Participants in the Groups & \\
\hline & Not performed & 0 \\
\hline & Performed without intent-to-treat analysis without inclusion of all randomized participants & 1 \\
\hline & All participants included with or without intent-to-treat analysis & 2 \\
\hline \multirow[t]{4}{*}{13.} & Description of Drop Out Rate & \\
\hline & No description of dropouts, despite reporting of incomplete data or $\geq 20 \%$ withdrawal & 0 \\
\hline & Less than $20 \%$ withdrawal in one year in any group & 1 \\
\hline & Less than $30 \%$ withdrawal at 2 years in any group & 2 \\
\hline \multirow[t]{4}{*}{14.} & Similarity of Groups at Baseline for Important Prognostic Indicators & \\
\hline & Groups dissimilar with significant influence on outcomes with or without appropriate randomization and allocation & 0 \\
\hline & Groups dissimilar without influence on outcomes despite appropriate randomization and allocation & 1 \\
\hline & Groups similar with appropriate randomization and allocation & 2 \\
\hline
\end{tabular}


Appendix Table 2 con't. Item checklist for assessment of randomized controlled trials of IPM techniques utilizing IPM-QRB.

\begin{tabular}{|c|c|c|}
\hline & & Scoring \\
\hline \multirow[t]{3}{*}{15.} & Role of Co-Interventions & \\
\hline & Co-interventions were provided but were not similar in the majority of participants & 0 \\
\hline & No co-interventions or similar co-interventions were provided in the majority of the participants & 1 \\
\hline V. & RANDOMIZATION & \\
\hline \multirow[t]{4}{*}{16.} & Method of Randomization & \\
\hline & Quasi randomized or poorly randomized or not described & 0 \\
\hline & Adequate randomization (coin toss, drawing of balls of different colors, drawing of ballots) & 1 \\
\hline & $\begin{array}{l}\text { High quality randomization (Computer generated random sequence, pre-ordered sealed envelopes, sequentially ordered } \\
\text { vials, telephone call, pre-ordered list of treatment assignments, etc.) }\end{array}$ & 2 \\
\hline VI. & ALLOCATION CONCEALMENT & \\
\hline \multirow[t]{4}{*}{17.} & Concealed Treatment Allocation & \\
\hline & Poor concealment of allocation (open enrollment) or inadequate description of concealment & 0 \\
\hline & Concealment of allocation with borderline or good description of the process with probability of failure of concealment & 1 \\
\hline & High quality concealment with strict controls (independent assignment without influence on the assignment sequence) & 2 \\
\hline VII. & BLINDING & \\
\hline \multirow[t]{3}{*}{18.} & Patient Blinding & \\
\hline & Patients not blinded & 0 \\
\hline & Patients blinded adequately & 1 \\
\hline \multirow[t]{3}{*}{19.} & Care Provider Blinding & \\
\hline & Care provider not blinded & 0 \\
\hline & Care provider blinded adequately & 1 \\
\hline \multirow[t]{3}{*}{20.} & Outcome Assessor Blinding & \\
\hline & Outcome assessor not blinded or was able to identify the groups & 0 \\
\hline & $\begin{array}{l}\text { Performed by a blinded independent assessor with inability to identify the assignment-based provider intervention (i.e., } \\
\text { subcutaneous injection, intramuscular distant injection, difference in preparation or equipment use, numbness and } \\
\text { weakness, etc.) }\end{array}$ & 1 \\
\hline VIII. & CONFLICTS OF INTEREST & \\
\hline \multirow[t]{7}{*}{21.} & Funding and Sponsorship & \\
\hline & Trial included industry employees & -3 \\
\hline & $\begin{array}{l}\text { Industry employees involved; high levels of funding with remunerations by industry or an organization funded with } \\
\text { conflicts }\end{array}$ & -3 \\
\hline & Industry or organizational funding with reimbursement of expenses with some involvement & 0 \\
\hline & Industry or organization funding of expenses without involvement & 1 \\
\hline & Funding by internal resources only with supporting entity unrelated to industry & 2 \\
\hline & Governmental funding without conflict such as NIH, NHS, AHRQ & 3 \\
\hline \multirow[t]{8}{*}{22.} & Conflicts of Interest & \\
\hline & None disclosed with potential implied conflict & 0 \\
\hline & Marginally disclosed with potential conflict & 1 \\
\hline & Well disclosed with minor conflicts & 2 \\
\hline & Well disclosed with no conflicts & 3 \\
\hline & Hidden conflicts with poor disclosure & -1 \\
\hline & Misleading disclosure with conflicts & -2 \\
\hline & Major impact related to conflicts & -3 \\
\hline \multicolumn{2}{|c|}{ TOTAL } & 48 \\
\hline
\end{tabular}

Source: Manchikanti L, et al. Assessment of methodologic quality of randomized trials of interventional techniques: Development of an interventional pain management specific instrument. Pain Physician 2014; 17:E263-E290 (166). 
Appendix Table 3. IPM checklist for assessment of nonrandomized or observational studies of IPM techniques utilizing IPMQRBNR.

\begin{tabular}{|c|c|c|}
\hline & & Scoring \\
\hline I. & STUDY DESIGN AND GUIDANCE REPORTING & \\
\hline \multirow[t]{6}{*}{1.} & STROBE or TREND Guidance & \\
\hline & Case Report/Case Series & 0 \\
\hline & Study designed without any guidance & 1 \\
\hline & Study designed with minimal criteria and reporting with or without guidance & 2 \\
\hline & $\begin{array}{l}\text { Study designed with moderately significant criteria or implies it was based on STROBE or TREND without clear } \\
\text { description or the study was conducted before } 2011 \text { or similar criteria utilized with study conducted before } 2011\end{array}$ & 3 \\
\hline & $\begin{array}{l}\text { Designed with high level criteria or explicitly uses STROBE or TREND with identification of criteria or conducted } \\
\text { prior to } 2011\end{array}$ & 4 \\
\hline II. & DESIGN FACTORS & \\
\hline \multirow[t]{6}{*}{2.} & Study Design and Type & \\
\hline & Case report or series (uncontrolled - longitudinal) & 0 \\
\hline & Retrospective cohort or cross-sectional study & 1 \\
\hline & Prospective cohort case-control study & 2 \\
\hline & Prospective case control study & 3 \\
\hline & Prospective, controlled, nonrandomized & 4 \\
\hline \multirow[t]{4}{*}{3.} & Setting/Physician & \\
\hline & General setting with no specialty affiliation and general physician & 0 \\
\hline & Specialty of anesthesia/PMR/neurology, etc. & 1 \\
\hline & Interventional pain management with interventional pain management physician & 2 \\
\hline \multirow[t]{5}{*}{4.} & Imaging & \\
\hline & Blind procedures & 0 \\
\hline & Ultrasound & 1 \\
\hline & CT & 2 \\
\hline & Fluoro & 3 \\
\hline \multirow[t]{6}{*}{5.} & Sample Size & \\
\hline & Less than 100 participants without appropriate sample size determination & 0 \\
\hline & At least 100 participants in the study without appropriate sample size determination & 1 \\
\hline & Sample size calculation with less than 50 patients in each group & 2 \\
\hline & Appropriate sample size calculation with at least 50 patients in each group & 3 \\
\hline & Appropriate sample size calculation with 100 patients in each group & 4 \\
\hline \multirow[t]{4}{*}{6.} & Statistical Methodology & \\
\hline & None & 0 \\
\hline & Some statistics & 1 \\
\hline & Appropriate & 2 \\
\hline III. & PATIENT FACTORS & \\
\hline 7. & Inclusiveness of Population & \\
\hline \multirow[t]{5}{*}{ 7a. } & For epidural procedures: & \\
\hline & Poorly identified mixed population & 1 \\
\hline & Poorly identified mixed population with large sample $(\geq 200)$ & 2 \\
\hline & Clearly identified mixed population & 3 \\
\hline & $\begin{array}{l}\text { Disorders specific trials (i.e. well defined spinal stenosis and disc herniation, disorder specific, disc herniation or spinal } \\
\text { stenosis or post surgery syndrome) }\end{array}$ & 4 \\
\hline
\end{tabular}


Appendix Table 3 con't. IPM checklist for assessment of nonrandomized or observational studies of IPM techniques utilizing IPMQRBNR.

\begin{tabular}{|c|c|c|}
\hline & & Scoring \\
\hline \multirow[t]{5}{*}{$7 \mathrm{~b}}$. & For facet or sacroiliac joint interventions: & \\
\hline & No specific selection criteria & 1 \\
\hline & No diagnostic blocks based on clinical symptomatology & 2 \\
\hline & Selection with single diagnostic blocks & 3 \\
\hline & Selection with placebo or dual diagnostic blocks & 4 \\
\hline \multirow[t]{4}{*}{8.} & Duration of Pain & \\
\hline & Less than 3 months & 0 \\
\hline & 3 to 6 months & 1 \\
\hline & $>6$ months & 2 \\
\hline \multirow[t]{5}{*}{9.} & Previous Treatments & \\
\hline & Conservative management including drug therapy, exercise therapy, physical therapy, etc. & \\
\hline & Were not utilized & 0 \\
\hline & Were utilized sporadically in some patients & 1 \\
\hline & Were utilized in all patients & 2 \\
\hline \multirow[t]{5}{*}{10.} & Duration of Follow-up with Appropriate Interventions & \\
\hline & $\begin{array}{l}\text { Less than } 3 \text { months or less for epidural or facet joint procedures, etc., and } 6 \text { months for intradiscal procedures and } \\
\text { implantables }\end{array}$ & 1 \\
\hline & 3-6 months for epidural or facet joint procedures, etc., or one year for intradiscal procedures or implantables & 2 \\
\hline & 6-12 months for epidurals or facet joint procedures, etc., and 2 years or longer for discal procedures and implantables & 3 \\
\hline & $\begin{array}{l}18 \text { months or longer for epidurals and facet joint procedures, etc., or } 5 \text { years or longer for discal procedures and } \\
\text { implantables }\end{array}$ & 4 \\
\hline IV. & OUTCOMES & \\
\hline \multirow[t]{6}{*}{11.} & Outcomes Assessment Criteria for Significant Improvement & \\
\hline & $\begin{array}{l}\text { No descriptions of outcomes } \\
\text { OR } \\
<20 \% \text { change in pain rating or functional status }\end{array}$ & 0 \\
\hline & $\begin{array}{l}\text { Pain rating with a decrease of } 2 \text { or more points or more than } 20 \% \text { reduction } \\
\text { OR } \\
\text { functional status improvement of more than } 20 \%\end{array}$ & 1 \\
\hline & $\begin{array}{l}\text { Pain rating with decrease of } \geq 2 \text { points } \\
\text { AND } \\
\geq 20 \% \text { change or functional status improvement of } \geq 20 \%\end{array}$ & 2 \\
\hline & $\begin{array}{l}\text { Pain rating with a decrease of } 3 \text { or more points or more than } 50 \% \text { reduction } \\
\text { OR } \\
\text { functional status improvement with a } 50 \% \text { or } 40 \% \text { reduction in disability score }\end{array}$ & 2 \\
\hline & Significant improvement with pain and function $\geq 50 \%$ or 3 points and $40 \%$ reduction in disability scores & 4 \\
\hline \multirow[t]{4}{*}{12.} & Description of Drop Out Rate & \\
\hline & No description despite reporting of incomplete data or more than $30 \%$ withdrawal & 0 \\
\hline & Less than $30 \%$ withdrawal in one year in any group & 1 \\
\hline & Less than $40 \%$ withdrawal at 2 years in any group & 2 \\
\hline \multirow[t]{4}{*}{13.} & Similarity of Groups at Baseline for Important Prognostic Indicators & \\
\hline & No groups or groups dissimilar with significant influence on outcomes & 0 \\
\hline & Groups dissimilar without significant influence on outcomes & 1 \\
\hline & Groups similar & 2 \\
\hline \multirow[t]{3}{*}{14.} & Role of Co-Interventions & \\
\hline & Dissimilar co-interventions or similar co-interventions in some of the participants & 1 \\
\hline & No co-interventions or similar co-interventions in majority of the participants & 2 \\
\hline
\end{tabular}


Appendix Table 3 con't. IPM checklist for assessment of nonrandomized or observational studies of IPM techniques utilizing IPM$Q R B N R$.

\begin{tabular}{|c|c|c|}
\hline & & Scoring \\
\hline V. & ASSIGNMENT & \\
\hline \multirow[t]{5}{*}{15.} & Method of Assignment of Participants & \\
\hline & Case report/case series or selective assignment based on outcomes or retrospective evaluation based on clinical criteria & 1 \\
\hline & Prospective study with inclusion without specific criteria & 2 \\
\hline & Retrospective method with inclusion of all participants or random selection of retrospective data & 3 \\
\hline & $\begin{array}{l}\text { Prospective, well-defined assignment of methodology and inclusion criteria (quasi randomization, matching, } \\
\text { stratification, etc.) }\end{array}$ & 4 \\
\hline VI. & CONFLICTS OF INTEREST & \\
\hline \multirow[t]{7}{*}{16.} & Funding and Sponsorship & \\
\hline & Trial included industry employees with or without proper disclosure & -3 \\
\hline & $\begin{array}{l}\text { Industry employees involved; high levels of funding with remunerations by industry or an organization funded with } \\
\text { conflicts }\end{array}$ & -3 \\
\hline & $\begin{array}{l}\text { Industry or organizational funding with reimbursement of expenses with some involvement or no information } \\
\text { available }\end{array}$ & 0 \\
\hline & Industry or organization funding of expenses without involvement & 1 \\
\hline & Funding by internal resources only & 2 \\
\hline & Governmental funding without conflict such as NIH, NHS, AHRQ & 3 \\
\hline \multicolumn{2}{|c|}{ TOTAL MAXIMUM } & 48 \\
\hline
\end{tabular}

